\title{
WASTE ISOLATION PILOT PLANT LAND MANAGEMENT PLAN DOE/WIPP 93-004-Rev.
}

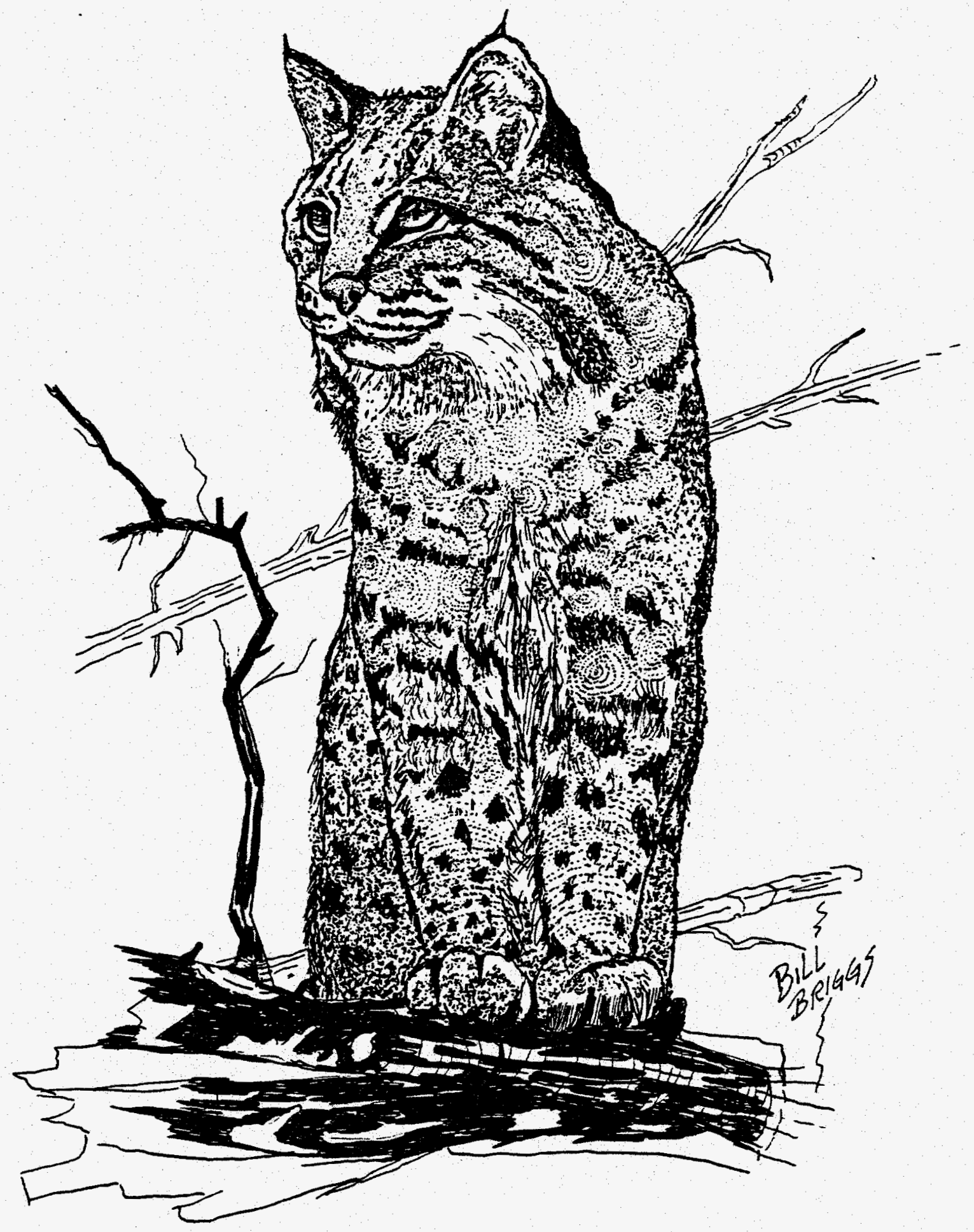




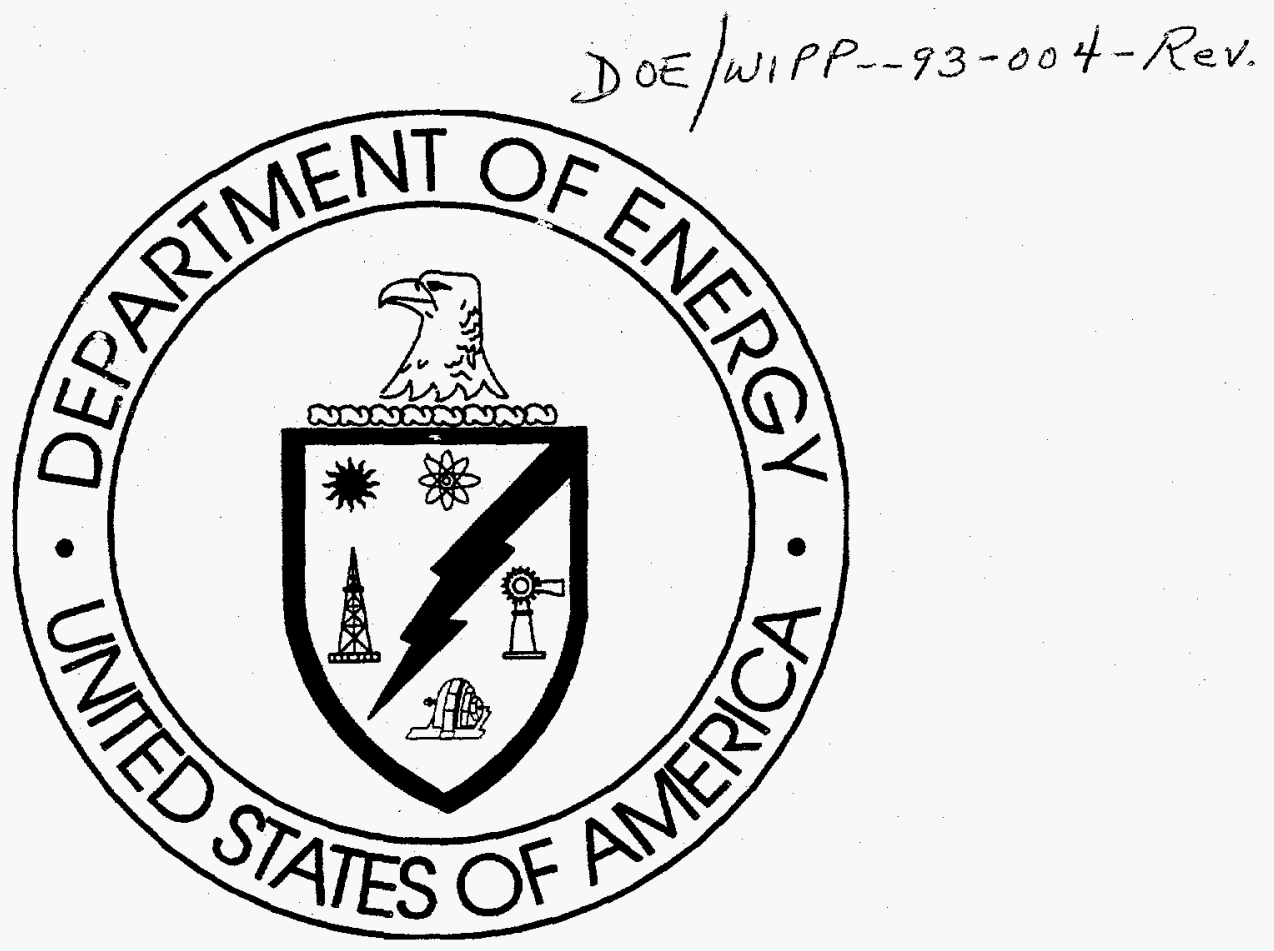

WASTE ISOLATION PILOT PLANT

LAND MANAGEMENT PLAN

DOE/WIPP - 93-004 
The majority of artworks contained in this Plan were courteously provided by W.E. "Bill" Briggs and C.H. "Chuck" Dyer. 


\section{DISCLAMMER}

Portions of this document may be illegible in electronic image products. Images are produced from the best available original document. 


\section{FOREWORD}

A prospective land user who has questions regarding elements of land management contained in this plan (see Table of Contents) or wishes to request access to Waste Isolation Pilot Plant (WIPP) lands should contact the U.S. Department of Energy (DOE) at. (505) 234-7303 or write the Carlsbad Area Office, P.O. Box 3090, Carlsbad, NM 88221. In the event of an emergency, call the WIPP Central Monitoring Room at 234-8125, 234-8457, or 234-8111.

Prior to submitting requests for land use, the requestor should examine the content of this document to identify those chapters that apply to the components of the respective activity, and provide for the implementation of adherence with WIPP land management edicts provided in this plan. For example, a potential user should read Chapter 2, "Environmental Compliance," to become familiar with the required permitting procedures and corresponding documentation.

It is the goal of the DOE to develop a "user-friendly" document that allows for reliable applications of management goals and objectives required to maintain site integrity, environmental quality and to sustain multiple-land use objectives where appropriate.

Through continual information sharing and timely updates of the Land Management Plan (LMP), the WIPP seeks to encourage improved land management practices based upon sound professional standards. Guidance prescribed by the LMP is useful for proposed activities, external as well as WIPP-related, that could impact lands used in the operation of the WIPP. 


\section{TABLE OF CONTENTS}

Foreword $\ldots \ldots \ldots \ldots \ldots \ldots \ldots \ldots \ldots \ldots \ldots \ldots$ ii

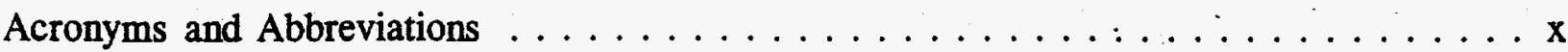

List of Figures $\ldots \ldots \ldots \ldots \ldots \ldots \ldots \ldots \ldots \ldots \ldots \ldots \ldots \ldots \ldots \ldots$

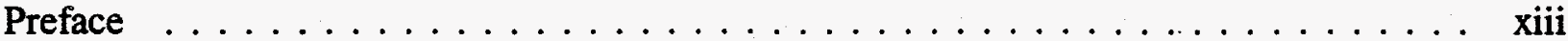

\section{CHAPTER 1 ADMINISTRATION OF THE LAND MANAGEMENT PLAN}

1.0 Introduction $\ldots \ldots \ldots \ldots \ldots \ldots \ldots \ldots \ldots \ldots \ldots \ldots \ldots \ldots \ldots \ldots \ldots \ldots \ldots \ldots .2$

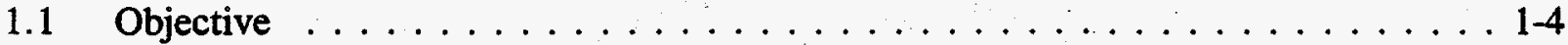

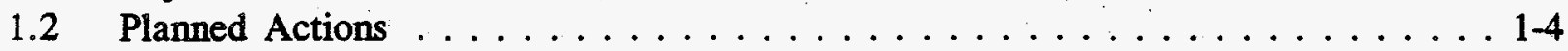

1.2.1 Maintaining the Land Management Plan . . . . . . . . . . 1-4

1.2.2 Updating, Amending, or Revising the Land Management

Plan . . . . . . . . . . . . . . . . . . . . 1-4

1.2.2.1 Updates $\ldots \ldots \ldots \ldots \ldots \ldots \ldots \ldots \ldots \ldots \ldots \ldots \ldots$

1.2.2.2 Amendments . . . . . . . . . . . . . 1-5

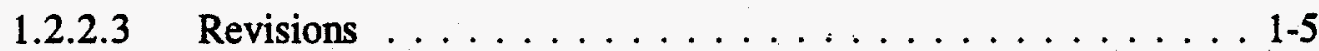

\section{CHAPTER 2 ENVIRONMENTAL COMPLIANCE}

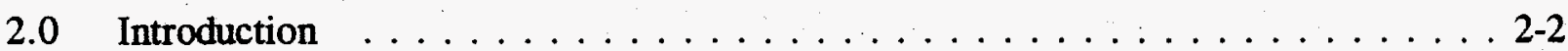

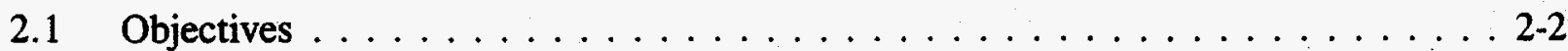

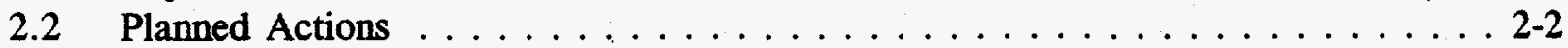

2.2.1 National Environmental Policy Act and Land Use of the Waste Isolation Pilot Plant Land Withdrawal Area . . . . . 2-3

2.2.1.1 Waste Isolation Pilot Plant Project Requests $\ldots \ldots \ldots \ldots$ 2-3

2.2.1.2 Land Use Request Review Process . . . . . . . . 2-3

2.2.2 Project Requests Through the Bureau of Land Management . . . . . 2-4

\section{CHAPTER 3 WILDLIFE}

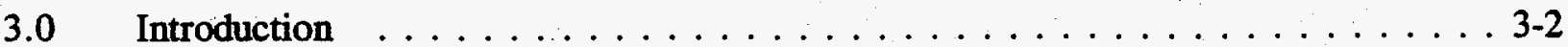

3.0.1 Affected Biological and Wildlife Environment $\ldots \ldots \ldots \ldots \ldots$ 3-2

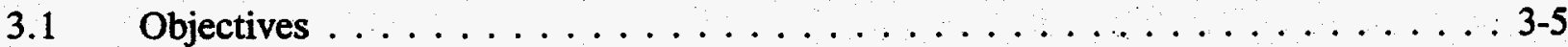

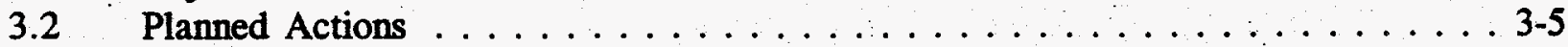

3.2.1 Raptors . . . . . . . . . . . . . . . . . . 3-5

3.2.2 Threatened and Endangered Species $\ldots \ldots \ldots \ldots \ldots \ldots . \ldots \ldots$ 
3.2.3 Ungulates $\ldots \ldots \ldots \ldots \ldots \ldots \ldots \ldots \ldots \ldots .6 \ldots .6 \ldots$

3.2 .4 Small Game . . . . . . . . . . . . . . .

3.2.4.1 Galliformes . . . . . . . . . . . . 3-7

3.2.5 Nongame Species $\ldots \ldots \ldots \ldots \ldots \ldots \ldots \ldots \ldots . . \ldots$ 3-8

3.2.5.1 Small Mammals . . . . . . . . . . . . 3-8

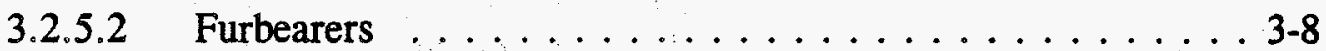

3.2.5.3 Small Birds . . . . . . . . . . . . . . 3-8

3.2.5.4 Reptiles . . . . . . . . . . . . . . . 3-9

\section{CHAPTER 4 CULTURAL RESOURCES}

4.0 Introduction $\ldots \ldots \ldots \ldots \ldots \ldots \ldots \ldots \ldots \ldots \ldots \ldots \ldots \ldots \ldots \ldots \ldots \ldots .2$

4.0.1 Cultural Resources in the Affected Environment $\ldots \ldots \ldots \ldots \ldots$. . . .

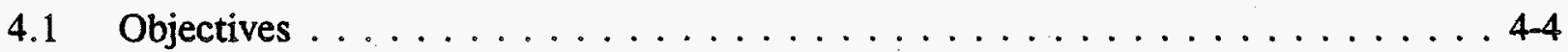

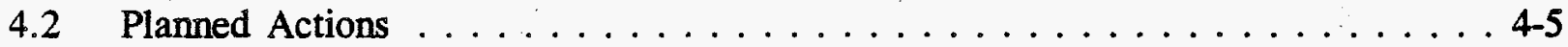

4.2.1 Cultural Resource Management . . . . . . . . . . . . 4-5

4.2.2 Field Surveillance $\ldots \ldots \ldots \ldots \ldots \ldots \ldots \ldots \ldots$ 4-5

4.2 .3 Reports on Survey Results $\ldots \ldots \ldots \ldots \ldots \ldots \ldots \ldots \ldots . \ldots .5$

$4.2 .4 \quad$ Report Reviews . . . . . . . . . . . . . . . . . . 4-6

4.2.5 Potentially Eligible Properties . . . . . . . . . . . . . 4-6

4.2.6 Project Clearances . . . . . . . . . . . . . . . . . . 4-6

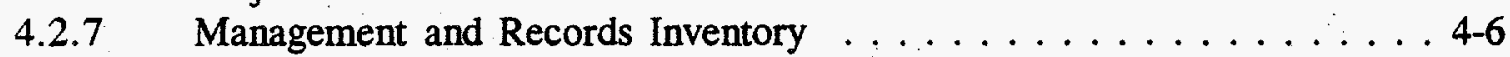

4.2.8 Information Disclosure $\ldots \ldots \ldots \ldots \ldots \ldots \ldots \ldots$. . . . . . .

\section{CHAPTER 5 - GRAZING}

5.0 Introduction $\ldots \ldots \ldots \ldots \ldots \ldots \ldots \ldots \ldots \ldots \ldots \ldots \ldots \ldots \ldots \ldots \ldots \ldots .2$

5.0.1 Grazing within the Affected Environment $\ldots \ldots \ldots \ldots \ldots \ldots$ 5-2

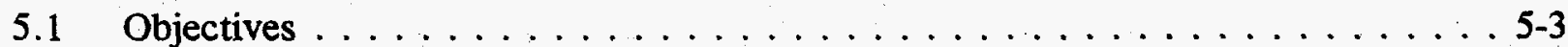

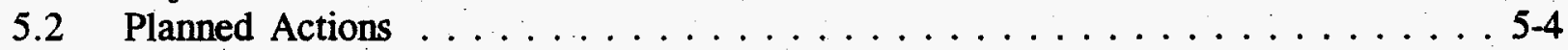

5.2 .1 Grazing Regulations . . . . . . . . . . . . . 5-4

5.2 .2 Configuration of Rangeland Improvements ... . . . . . . . 5-4

5.2 .3 Wildlife Access . . . . . . . . . . . . . . . . 5-4

5.2.4 Future Rangeland Improvements . ... . . . . . . . . . . 5-4

5.2 .5 Maintenance of Existing Improvements $\ldots \ldots \ldots \ldots \ldots \ldots \ldots$ 5-5

5.2.6 Violations of Existing Agreements $\ldots \ldots \ldots \ldots \ldots \ldots \ldots$ 5-5

5.2.7 Nonconformance with Grazing Requirements . . . . . . . . . 5-5

5.2 .8 Modifications to Improvements $\ldots \ldots \ldots \ldots \ldots \ldots \ldots \ldots$ 5-5 
5.2.9 Amending Grazing Rights $\ldots \ldots \ldots \ldots \ldots \ldots \ldots \ldots \ldots \ldots$

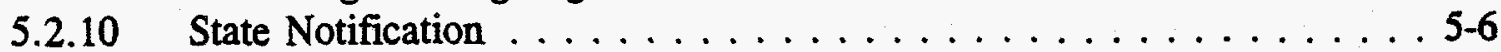

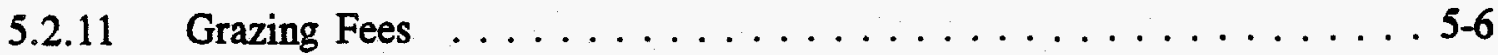

\section{CHAPTER 6 RECREATION}

6.0 Introduction $\ldots \ldots \ldots \ldots \ldots \ldots \ldots \ldots \ldots \ldots \ldots \ldots \ldots \ldots \ldots \ldots \ldots .2$

6.0.1 Recreation Within the Affected Environment $\ldots \ldots \ldots \ldots \ldots \ldots$ 6-2

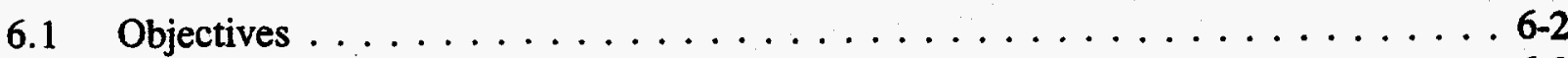

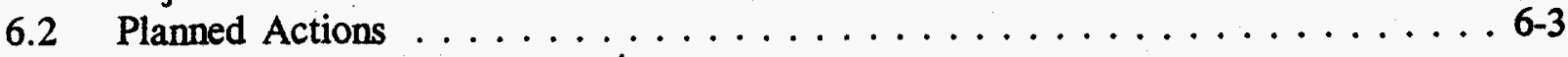

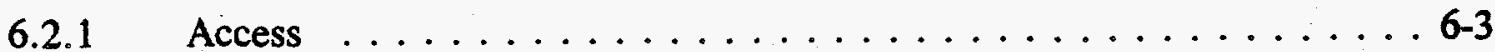

6.2 .2 Off-Road Vehicles $\ldots \ldots \ldots \ldots \ldots \ldots \ldots \ldots \ldots \ldots .3$

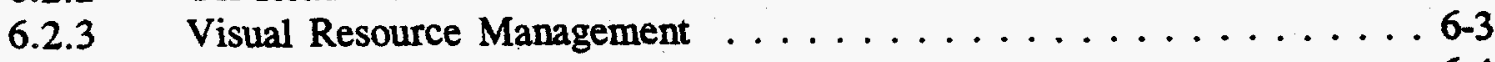

6.2 .4 Hunting and Trapping . . . . . . . . . . . . . . 6-4

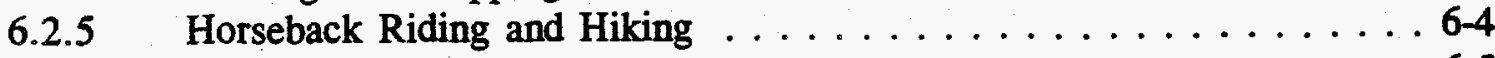

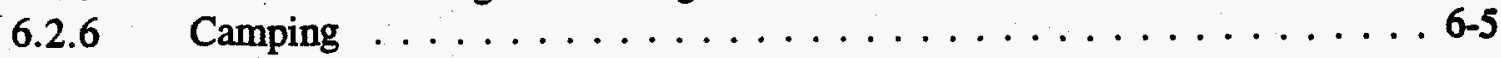

CHAPTER 7 ENERGY AND MINERAL RESOURCES

7.0 Introduction $\ldots \ldots \ldots \ldots \ldots \ldots \ldots \ldots \ldots \ldots \ldots \ldots \ldots \ldots \ldots \ldots \ldots .2$

7.0.1 Mineral Resources in Affected Environment $\ldots \ldots \ldots \ldots \ldots$ 7-2

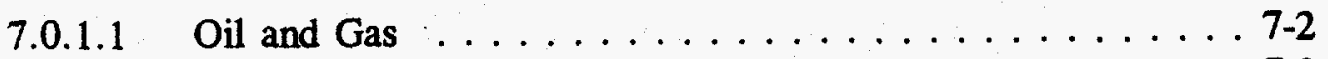

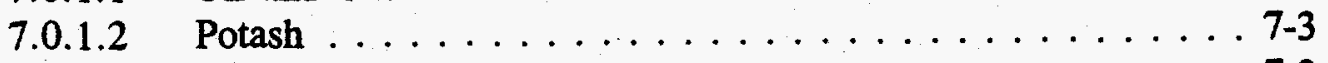

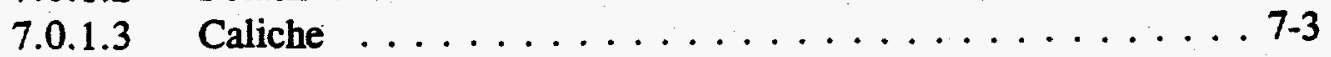

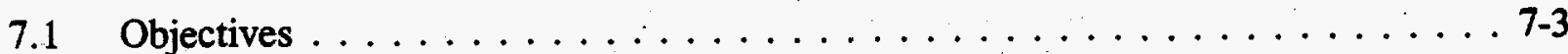

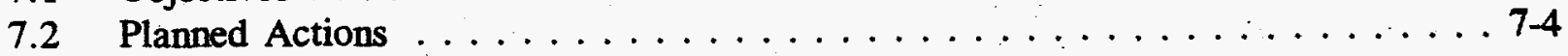

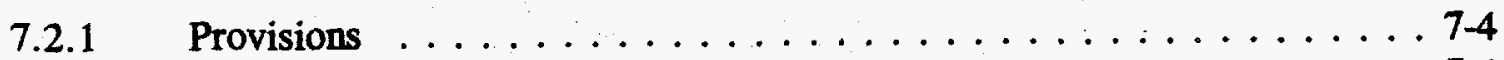

7.2 .2 Surveillance . . . . . . . . . . . . . . . . 7-4

7.2.3 Department of Energy Response to Applications for Permit to Drill . . 7-4

\section{CHAPTER 8 LANDS AND REALTY}

8.0 Introduction $\ldots \ldots \ldots \ldots \ldots \ldots \ldots \ldots \ldots \ldots \ldots \ldots .2$

8.0.1 Lands and Realty within the Affected Environment . . . . . . 8-2

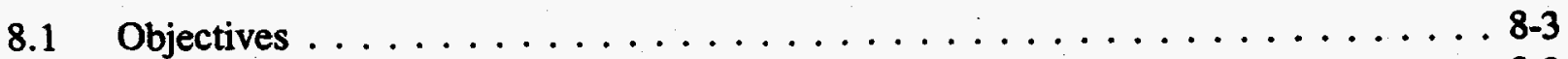

8.2 Planned Actions $\ldots \ldots \ldots \ldots \ldots \ldots \ldots \ldots \ldots \ldots \ldots . \ldots \ldots \ldots$

8.2.1 Proposals for New Access Routes $\ldots \ldots \ldots \ldots \ldots \ldots \ldots$ 8-3 
8.2.2 Utility Development $\ldots \ldots \ldots \ldots \ldots \ldots \ldots \ldots$. . . . . . . . . .

8.2.3 Avoidance Areas $\ldots \ldots \ldots \ldots \ldots \ldots \ldots \ldots \ldots . \ldots \ldots$

8.2 .4 Access Permits . . . . . . . . . . . . . . . 8-4

8.2 .5 Advertising $\ldots \ldots \ldots \ldots \ldots \ldots \ldots \ldots \ldots .4 \ldots \ldots$

8.2.6 Rights-of-Way, Rights-of-Way Corridors, and Realty Components . . 8-4

8.2.6.1 North Access Road . . . . . . . . . . . . . 8 8-4

8.2.6.2 South Access Road . . . . . . . . . . . . . . . 8-4

8.2.6.3 Water Service Pipeline . . . . . . . . . . 8 8-5

8.2.6.4 Access Railroad . . . . . . . . . . . . . 8-6

8.2.6.5 Transmission Line $\ldots \ldots \ldots \ldots \ldots \ldots . . . . . .6-6$

8.2.6.6 High-Pressure Gas Line . . . . . . . . . . . . 8 8-6

8.2 .6 .7 Sewage Lagoon $\ldots \ldots \ldots \ldots \ldots \ldots . \ldots . . \ldots .7$

8.2.6.8 Groundwater Surveillance Wells . . . . . . . . . 8-7

8.2.6.9 Salt Tailings Stockpiles . . . . . . . . . . . 8-8

\section{CHAPTER 9 RECLAMATION/ENVIRONMENTAL RESTORATION}

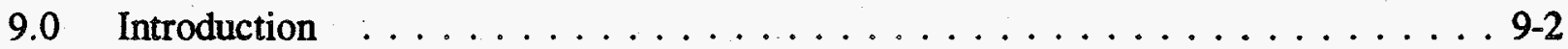

9.0.1 Reclamation in the Affected Environment $\ldots \ldots \ldots \ldots \ldots . \ldots .2$

9.1 Objectives . . . . . . . . . . . . .

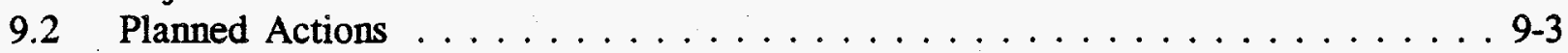

9.2.1 Timeliness of Reclamation Projects . . . . . . . . . . . . 9-3

9.2.2 Review of Reclamation Activities . . . . . . . . . . . . 9-3

9.2.3 Fencing of Reclamation Sites . . . . . . . . . . . . 9-3

9.2.4 Reclamation Protocol . . . . . . . . . . . . . . . . 9-3

9.2.5 Prioritization of Reclamation Sites $\ldots \ldots \ldots \ldots \ldots \ldots . \ldots .4$

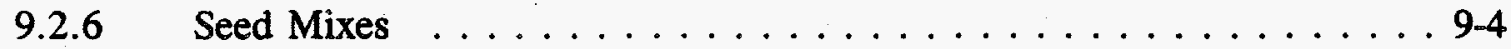

9.2.7 Reseeding of Sites $\ldots \ldots \ldots \ldots \ldots \ldots \ldots \ldots \ldots \ldots . \ldots \ldots$

9.2.8 Reclamation and Cultural Resources . . . . . . . . . . . . . . 9-4

9.2.9 Decommissioning of the Waste Isolation Pilot Plant $\ldots \ldots \ldots$. . . .

\section{CHAPTER 10 SECURITY}

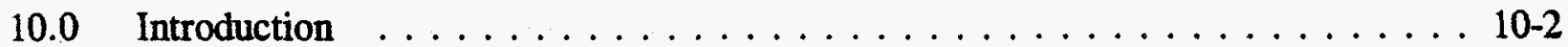

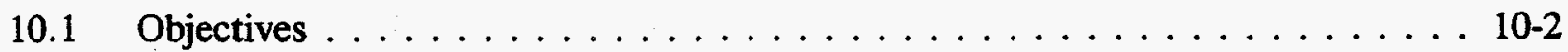

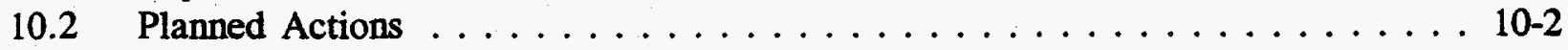

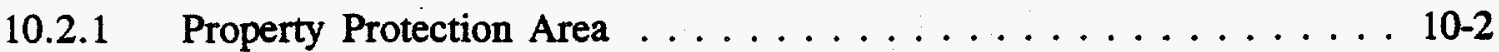

10.2.2 Exclusive Use Area $\ldots \ldots \ldots \ldots \ldots \ldots \ldots \ldots \ldots \ldots \ldots \ldots . \ldots \ldots$

10.2.3 Off-Limits Area . . . . . . . . . . . . . . . . 10-3

10.2.4 Waste Isolation Pilot Plant Land Withdrawal Area $\ldots \ldots \ldots \ldots$ 10-3

10.2.5 Special Management Areas $\ldots \ldots \ldots \ldots \ldots \ldots \ldots \ldots \ldots$ 10-3 


\section{CHAPTER 11 EMERGENCY MANAGEMENT}

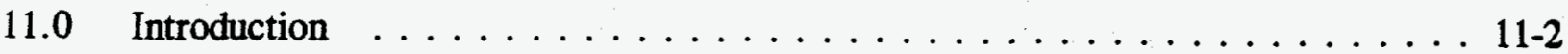

11.0.1 Emergency Services and the Affected Environment ........ 11-2

11.0.2 Responsibilities ..................... 11-3

11.0.2.1 Emergency Service Technician/Incident Commander . . . 11-3

11.0.2.2 Emergency Response Team . . . . . . . . . . . . . 11-3

11.0.2.3 Backshift Fire Brigade . . . . . . . . . . . . . 11-3

11.0.2.4 Central Monitoring Room Operator ............ 11-3

11.0.2.5 Facility Shift Manager . . . . . . . . . . . . . 11-4

11.0.2.6 Resource Conservation and Recovery Act

Emergency Coordinator/Crisis Manager . . . . . . . . 11-4

11.0.2.7 Emergency Operations Center ... . . . . . . . . . 11-4

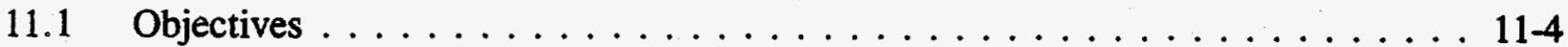

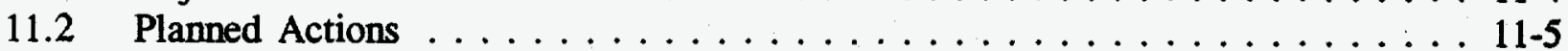

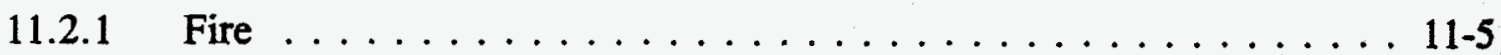

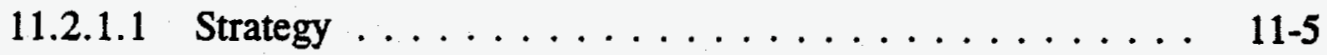

11.2.1.2 Resources ..................... 11-5

11.2.1.3 Reporting . . . . . . . . . . . . . . 11-5

11.2.2 Radioactive and Hazardous Materials ............ 11-6

11.2.2.1 Strategy . . . . . . . . . . . . . . 11-6

11.2.2.2 Reporting ................... 11-6

\section{CHAPTER 12 INDUSTRIAL SAFETY}

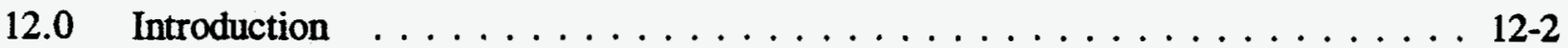

12.1 Objectives .............................. $\ldots \ldots$

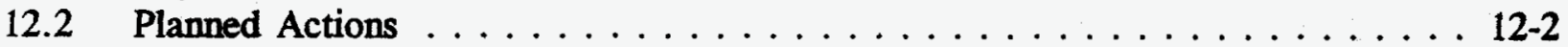

12.2.1 Work Performed by Waste Isolation Pilot Plant Employees . . . . . . 12-3

12.2.2 Safety Requirements for Subcontractors . . . . . . . . . . . 12-3

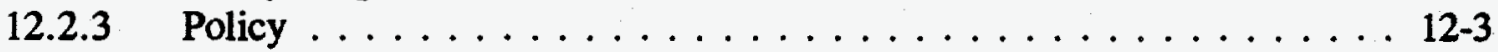

12.2.4 General Guidelines ...................... . . $12-4$

12.2.5 Prior to Commencement of Work . . . . . . . . . . . . . . 12-4

12.2.6 Submittals Required by Subcontractors $\ldots \ldots \ldots \ldots \ldots \ldots \ldots \ldots$

12.2.6.1 Construction Subcontractors (Davis-Bacon Work) . . . . . 12-4

12.2.6.2 Maintenance Contractors (Non-Davis-Bacon Work) . . . . 12-5 
12.2.7 Waste Isolation Pilot Plant Responsibilities . . . . . . . . . 12-5

12.2.7.1 Waste Isolation Division Procurement Services . . . . . . 12-6

12.2.7.2 Waste Isolation Pilot Plant Subcontract Technical Representative Responsibilities . . . . . . . . . . 12-6

12.2.8 Procedure for Reporting Accidents . . . . . . . . . . . . . 12-6

12.2.9 Subcontractor Safety Procedures $\ldots \ldots \ldots \ldots \ldots \ldots \ldots$. . . . . . . . .

12.2.9.1 Personal Protective Equipment $\ldots \ldots \ldots \ldots \ldots \ldots$ 12-7

12.2.9.2 Safety Meetings . . . . . . . . . . . . . . . . 12-7

12.2.9.3 Subcontractor Procedures . . . . . . . . . . 12-8

12.2.10 Housekeeping Inspections $\ldots \ldots \ldots \ldots \ldots \ldots \ldots \ldots \ldots \ldots$ 12-8

\section{CHAPTER 13 MAINTENANCE AND WORK CONTROL}

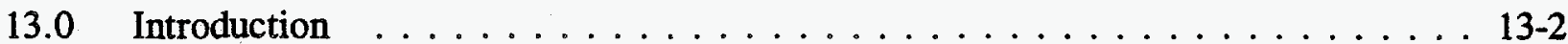

13.1 Objectives . . . . . . . . . . . . . . . . . . . . .

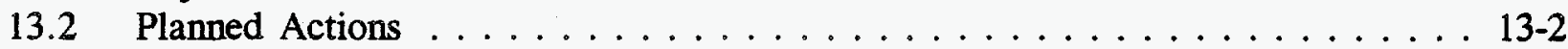




\section{APPENDIX A}

Land Management Council Directives $\ldots \ldots \ldots \ldots \ldots \ldots \ldots \ldots \ldots \ldots$

\section{APPENDIX B}

Guide for the Completion of a Land Use Request $\ldots \ldots \ldots \ldots \ldots \ldots$

\section{APPENDIX C}

Memorandum of Understanding Between the U.S. Department of Energy

and the U.S. Department of Interior . . . . . . . . . . . . . . . . . C-1

\section{APPENDIX D}

Waste Isolation Pilot Plant Statement of Work for the Bureau of Land Management . . . D-

\section{APPENDIX E}

Interagency Agreement 1422G910-A2-0016 Between the Department of Energy and the Bureau of Land Management, Raptor

Research and Management Program ...................... E-1

\section{APPENDIX F}

Memorandum of Understanding between the U.S. Department of Energy and the New Mexico Department of Public Safety Concerning Mutual Assistance and Emergency Management, GM-04-91AL58221 . . . . . . . . . . . . . F-

\section{APPENDIX G}

Implementing Regulations Regarding Cultural Resources $\ldots \ldots \ldots \ldots \ldots \ldots$. . . . . . 


\section{ACRONYMS AND ABBREVIATIONS}

APD

API

ASER

AUM

BECR

BFB

BLM

CAO

CFR

CMR

CMRO

DOE

DOE-AL

DOI

EA

EMNRD

EOC

ERO

ERT

EPA

ER

ES\&H

EST

FEIS

FLPMA

FSM

GSP

HAZMAT

IMC

LMC

LMIP

LMP

LUC

LUR

LWA
Application for Permit to Drill

American Petroleum Institute

Annual Site Environmental Report

Animal Unit Month

Biennial Environmental Compliance Report

Backshift Fire Brigade

Bureau of Land Management

Carlsbad Area Office (of the DOE)

Code of Federal Regulations

Central Monitoring Room

Central Monitoring Room Operator

(United States) Department of Energy

(United States) Department of Energy Albuquerque Operations Office

(United States) Department of Interior

Environmental Assessment

(New Mexico) Environment, Minerals, and Natural Resources Department

Emergency Operation Center

Emergency Response Organization

Emergency Response Team

(United States) Environmental Protection Agency

Environmental Review

Environment, Safety and Health

Emergency Services Technician

Final Environmental Impact Statement

Federal Land Policy and Management Act

Facility Shift Manager

Groundwater Surveillance Program

Hazardous Materials

International Minerals and Chemical Corporation

Land Management Council

Land Management Implementation Plan

Land Management Plan

Land Use Coordinator

Land Use Request

(WIPP) Land Withdrawal Act 


\begin{tabular}{|c|c|}
\hline MCF & Thousand Cubic Feet \\
\hline MOU & Memorandum of Understanding \\
\hline MSDS & Material Safety Data Sheet \\
\hline MSHA & Mine Safety and Health Administration of the U.S. Department of Labor \\
\hline NEPA & National Environmental Policy Act \\
\hline NMDG\&F & New Mexico Department of Game and Fish \\
\hline NMED & New Mexico Environment Department \\
\hline ORV & Off-Road Vehicle \\
\hline OSHA & $\begin{array}{l}\text { Occupational Safety and Health Administration of the U.S. Department of } \\
\text { Labor }\end{array}$ \\
\hline P.L. & Public Law \\
\hline PPE & Personal Protective Equipment \\
\hline RCRA & Resource Conservation and Recovery Act \\
\hline RMP & Resource Management Plan \\
\hline SEIS & Supplement Environmental Impact Statement \\
\hline SG & Grassland (Short-grass Prairie) \\
\hline SHPO & State Historic Preservation Officer \\
\hline SMA & Special Management Area \\
\hline SNL & Sandia National Laboratories \\
\hline SOD & Shin Oak/Dune Habitat \\
\hline SPDV & Site and Preliminary Design Validation \\
\hline SRS & Supervisory Realty Specialist \\
\hline STR & Subcontract Technical Representative \\
\hline$T \& E$ & Threatened and Endangered \\
\hline TRU & Transuranic \\
\hline U.S.C & United States Code \\
\hline USF\&WS & United State Fish and Wildlife Service \\
\hline WID & Waste Isolation Division of the Westinghouse Electric Corporation \\
\hline WLWA & WIPP Land Withdrawal Area \\
\hline WIPP & Waste Isolation Pilot Plant \\
\hline WP & WIPP Procedure \\
\hline
\end{tabular}




\section{LIST OF FIGURES}

Figure

\section{1}

5.1

7.1

8.1

10.1

13.1
Title
Page

Flow Chart for Land Use Request and Notification Process . . . . . . . . 2-7

Grazing Allotment Boundaries Within the WIPP Site Boundary $\ldots \ldots$. . 5-7

Oil and Gas Wells Within One Mile of the WIPP Land Withdrawal Area . . 7-6

Major Access and Rights-of-Way for the WIPP Site $\ldots \ldots \ldots \ldots$. . . 8-9

Security Zones Within the WIPP Site Boundary . . . . . . . . . 10-4

Roads and Well Pads Used in the Operation of the WIPP

$13-5$ 


\section{PREFACE}

In accordance with Section 4 of the Waste Isolation Pilot Plant (WIPP) Land Withdrawal Act (LWA) (Public Law 102-579), the DOE has prepared this Land Management Plan (LMP) as required by the Act. The development of this plan is in concert with the U.S. Department of Interior's (DOI) Bureau of Land Management (BLM) and the state of New Mexico. Changes or amendments to this plan shall be done in consultation with the BLM, the state of New. Mexico, and affected stakeholders, as appropriate.

This LMP, as required by LWA, has been prepared to identify resource values, promote the concept of multiple-use management, and identify long-term goals for the management of WIPP lands until the culmination of the decommissioning phase. This plan also provides the opportunity for participation in the land use planning process by the public, as well as local, state, and federal agencies.

This document is a reprint of the LMP which incorporates elements of implementation previously provided in the WIPP Land Management Implementation Plan (LMIP) (DOE/WIPP 94-026). This reprint does not revise or amend the intent or scope of the original plan, but merges implementing actions from the LMIP to make the plan more helpful for those desiring to use WIPP lands. An additional reason for developing this reprint was to reduce document volume and redundancies in text, which results in the LMIP being superseded by this LMP.

This plan is prepared through the integration of the WIPP Land Withdrawal Act of 1992 (Public Law 102-579), BLM planning regulations (43 CFR 1600) issued under the authority of the Federal Land Policy and Management Act (FLPMA) of 1976, the National Environmental Policy Act (NEPA) of 1969, as amended; and existing Memoranda of Understanding (MOU) among the DOE and local, state and/or federal agencies. The LMP is designed to provide a comprehensive framework for the management and coordination of WIPP land uses during the life of the project. The LMP, and any subsequent amendments, will continue through the decommissioning phase. Moreover, in accordance with section 13 of the WIPP Land Withdrawal Act, the DOE will develop, in consultation with the Secretary of the Interior and the State of New Mexico, a plan for the management and use of the WIPP Land Withdrawal Area following the decommissioning of WIPP. This plan must be developed by October 30, 1997.

The guidelines prescribed in the LMP provide for the management and oversight of WIPP lands under the jurisdiction of the DOE in addition to lands outside the WIPP boundary that are used in the operation of the WIPP (e.g., groundwater surveillance well pads outside the withdrawn area). Furthermore, this plan provides for multiagency involvement in the administration of DOE land management actions. Documents referenced in the LMP are available to any person and/or organization desiring to conduct activities on lands under the jurisdiction of the WIPP in addition to those involved in development and/or amending existing land management actions. Documents can be obtained from the U.S. 
Department of Energy, Carisbad Area Office, P.O. Box 3090, Carlsbad, New Mexico 88221 .

This LMP envisions and encourages direct communication among stakeholders, including federal and state agencies involved in managing the resources within, or activities impacting the areas adjacent to, the WIPP Land Withdrawal Area (WLWA). It sets forth cooperative arrangements and protocols for addressing WIPP-related land management actions. The DOE recognizes the guidelines for contemporary land management practices that pertain to rational adherence with edicts in the WIPP LWA and all applicable regulatory requirements contained therein. Commitments contained in current permits, agreements, or concurrent MOUs with other agencies (e.g., state of New Mexico, DOI), shall be adhered to when addressing/evaluating land use management activities and future amendments that affect the management of WIPP lands.

This LMP will be reviewed on a biennial basis to assess the adequacy and effectiveness of the document, or as may be necessary to address emerging issues potentially affecting WIPP lands. Affected agencies, groups, and/or individuals may be involved in the review process.

The contents of the LMP focus on management protocols for the following issues: administration of the plan; environmental compliance; wildlife; cultural resources; grazing; recreation; energy and mineral resources; lands/realty; reclamation; security; industrial safety; emergency management; maintenance and work control. Each issue and its complementary planning/management criteria are described in the respective chapters. 


\section{CHAPTER 1}

\section{ADMINISTRATION OF THE LAND MANAGEMENT PLAN}



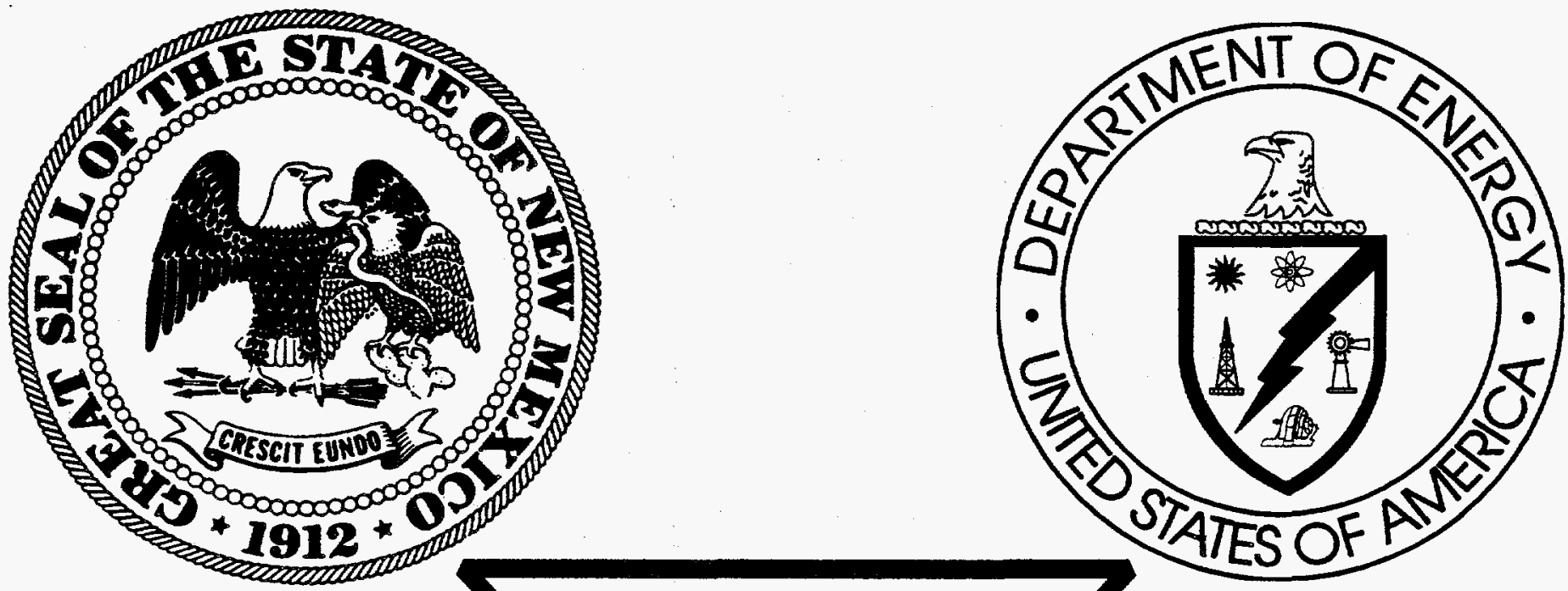

U.S. DEPARTMENT OF THE INTERIOR BUREAU OF LAND MANAGEMENT

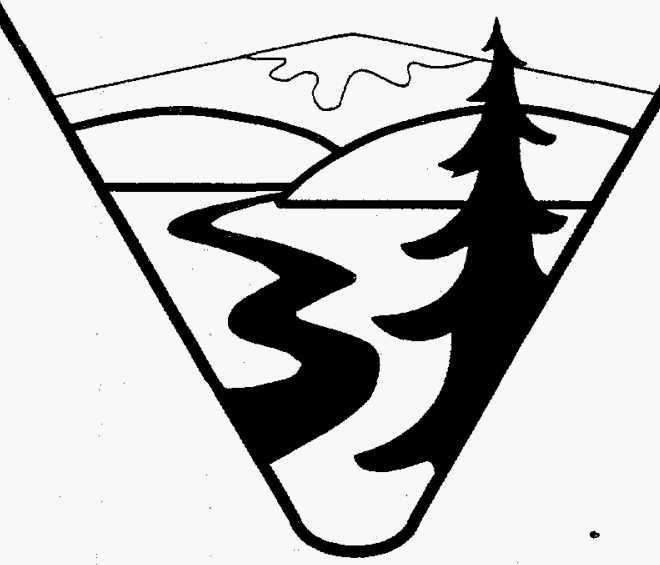




\section{CHAPTER 1}

\section{ADMINISTRATION OF THE WIPP LAND MANAGEMENT PLAN}

\subsection{INTRODUCTION}

On October 30, 1992, the WIPP Land Withdrawal Act (P.L. 102-579) became law. This Act transferred the responsibility for the management of the WIPP Land Withdrawal Area (WLWA) (see Figure 10.1) from the Secretary of the Interior to the Secretary of Energy. In accordance with sections $3(a)(1)$ and (3) of the Act, these lands ". . . are withdrawn from all forms of entry, appropriation, and disposal under the public land laws ...." and are reserved for the use of the Secretary of Energy ". . . for the construction, experimentation, operation, repair and maintenance, disposal, shutdown, monitoring, decommissioning, and other activities, associated with the purposes of WIPP as set forth in Section 213 of the Department of Energy National Security and Military Applications of Nuclear Energy Act of 1980 (P.L. 96-164; 93 Stat. 1259, 1265) and this Act."

As a complement to this LMP, a MOU has been executed between the DOE and the BLM, as required by section 4(d) of the Act. The state of New Mexico was consulted in the development of the MOU and the associated Statement of Work (SOW).

\subsubsection{Affected Environment}

The WIPP facility, a project of the United States Department of Energy (DOE), was authorized by P.L. $96-164$ to provide a research and development facility to demonstrate the safe disposal of radioactive wastes resulting from the defense activities and programs of the United States.

The WIPP Site is located in Eddy County in Southeastern New Mexico. The site is 26 miles east of Carlsbad, New-Mexico, in a region known as the Los Medaños, that represents the initial intergradation between the Llano Estacado and the Chihuahuan Desert. This region displays an exceptional diversity of plant and animal inhabitants.

Geographically, the region is regarded as a relatively flat, sparsely inhabited plateau with little surface water. Demographically, there are approximately 26 residents at various locations within 10 miles of the WIPP site. The majority of the local population within 50 miles of the WIPP are concentrated in and around the communities of Carlsbad, Hobbs, Eunice, Jal, and Artesia, New Mexico. The nearest community is the village of Loving, 
New Mexico, 18 miles west-southwest of the WIPP. The population of Loving decreased from an estimated 1600 in 1980 to 1240 in 1990 with a current population estimate of 1291 . The nearest major populated area is Carlsbad, New Mexico, 26 miles west of the WIPP. The population of Carisbad decreased from an estimated 25,496 in 1980 to an estimated 24,952 in 1990 with a current estimated population of 26,974 . [Population estimates are calculated by subtracting the number of deaths from the number of births and adding net migration.] The transient population within 10 miles of the WIPP is associated with ranching, oil and gas exploration/production, and potash mining. The region is popular for recreation, providing opportunities for hunting, camping, hiking, and bird watching.

\subsubsection{Implementation of the WIPP Land Management Plan}

WIPP land management authorizations and actions, including budget proposals, will not create conflict with this LMP. Valid existing rights, operations, and activities under existing permits, contracts, cooperative agreements, MOUs, or other instruments for land use are evaluated to assure that the Land Use Request (LUR) process complies with the intent of existing permits and/or agreements.

Actions in the LMP shall be implemented over a period extending through decommissioning phase of the WIPP facility. In some cases, site-specific planning and environmental analyses more detailed than those required by this LMP may be required before an action can be taken.

This LMP will be reviewed biennially and updated as needed to reflect new management direction, program policy, and monitoring results, or to respond to changing congressional mandates. Amendments or revisions to this plan will be developed in consultation with the BLM and the state of New Mexico and promptly submitted to the Congress and the state of NM as required by section $4(e)$ of the Act.

As implementation of this plan proceeds, proposed land use projects not addressed in this plan will be evaluated in regards to the intent of this plan to determine conformance with the plan's objectives. The Land Management Council (LMC), convened in accordance with prescribed guidelines (Appendix A), shall review all proposals through the LUR process for this purpose, as defined in Chapter 2 of this plan. The LMC will determine if management actions contained in the LUR are provided for specifically in this plan or, if not mentioned, if they are clearly consistent with the terms, conditions; and decisions of the approved plan.

It is not the intent of the DOE to administer surface uses, within the extent of the WIPP Land Withdrawal Area (WLWA), as a WIPP exclusive use area. The goal of the DOE is to manage the surface of the WLWA using traditional multiple land use concepts. Accordingly, land-use restrictions will be minimized to the extent possible.

The subsurface of the WLWA is restricted to exclusive use by the WIPP with the exception of two 320-acre tracts that are leased for oil and gas development below 6000 feet. These subject tracts are identified as Federal Oil and Gas Leases No. NMNM 02953 and NMNM 02953C of Section 31, Township 22 South, Range 31 East. Restrictions pertaining 
to subsurface properties are needed to protect the long-term integrity of the WIPP disposal system. In addition, it is the intent of the DOE that, during repository operations, safety and security will be maintained.

In accordance with section 4(c) of the Act, if the Secretary of Energy determines, in consultation with the Secretary of the Interior, that the health and/or safety of the public or the common defense and security require the closure to the public of any road, trail, or other portion of the withdrawal area, the DOE will take whatever action the Secretary determines to be necessary to effect and maintain the closure and shall provide notice (to the public) of such closure.

\subsection{OBJECTIVE}

The objective of this LMP is to provide the DOE with land management guidelines in addition to establishing criteria for review and implementation of land management decisions. These appraisals allow the DOE to evaluate the effectiveness of multiple-use decisions, and will provide guidance for the evaluation of productivity, condition, quality, or other issues related to land-management actions. Implementation and monitoring plans for each respective land resource are discussed in subsequent chapters of this document.

\subsection{PLANNED ACTIONS}

Planned actions are those associated with the review and update of this LMP. These are presented to assure timely review and update of the LMP and to establish consistency with current regional land management practices, DOE policy, and congressional directives.

\subsubsection{Maintaining the Land Management Plan}

The LMP shall be maintained efficiently through timely modifications which document new data, minor changes (e.g., amendments to existing regulations), or corrections, and which have undergone appropriate WIPP document review procedures. These modifications will not expand the scope or level of resource decisions, conditions, or terms prescribed in the LMP.

\subsubsection{Updating, Amending, or Revising the Land Management Plan}

The LMP may be updated, amended, or revised by the LMC, as described in Appendix A, when considering a proposal or an action that is not addressed by the LMP. Categories of plan changes are discussed below.

\subsubsection{Updates}

This category is used to define activities designated as "low impact" by the LMC. The purpose of this category is to designate proposal(s) that the $\mathrm{LMC}$, in consultation with cognizant regulatory personnel, has identified as not being addressed specifically in the LMP and as not having significant environmental impact. A LUR shall be submitted to the LMC 
for status determination. DOE NEPA Compliance Coordinator will assess the project for determination (e.g., DOE/NEPA categorical exclusion). Updates do not require a plan. alteration.

\subsubsection{Amendments}

This category is used when preliminary analysis by the LMC indicates that proposal(s) not specifically addressed in the LMP have, or are likely to have, significant environmental impacts that would necessitate the development of an Environmental Assessment (EA). In this case the LMC and/or cognizant regulatory personnel, will evaluate regulatory impacts and possible permit requirements and request a National Environmental Policy Act (NEPA) determination from the DOE. Actions (e.g., document modifications) that are determined, by the LMC, as amendments will require stakeholder notification and subsequent submittal to Congress.

\subsubsection{Revisions}

This category is used when a proposal(s) not specifically addressed in the LMP will have a significant impact. A revision of the LMP may involve the preparation of a new LMP when updates or amendments can no longer keep the existing plan current with existing environmental impact statements (EIS), changing management needs, resource conditions, policies, or regulatory laws. Plan revisions will be considered only after a comprehensive review by the LMC and cognizant regulatory personnel. Revisions will be submitted to Congress, evaluated by all affected stakeholders, and may include formal, public involvement. A revision likely would result in a significant mission or regulatory change and would be conducted in accordance with all pertinent DOE planning policies. 


\section{CHAPTER 2}

\section{ENVIRONMENTAL COMPLIANCE}




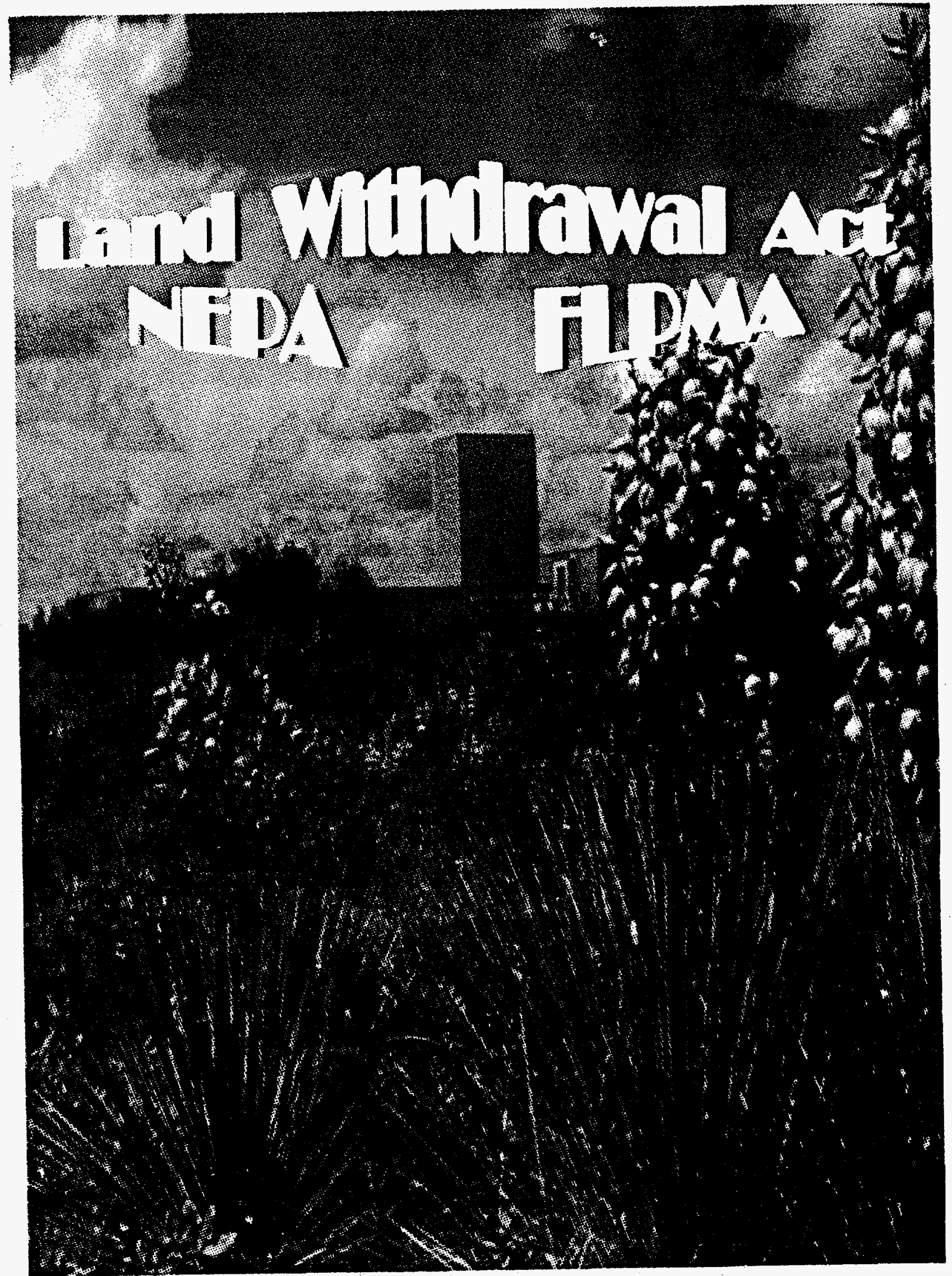




\section{CHAPTER 2 ENVIRONMENTAL COMPLIANCE}

\subsection{INTRODUCTION}

Parties who desire to conduct activities that have the potential to impact the WIPP Land Withdrawal Area (WLWA), outside the perimeter of the Property Protection Area (see Figure 10.1), must prepare a Land Use Request (LUR) (Appendix B). This includes activities that originate outside the WLWA but will directly affect properties within the WLWA, or on lands outside the WLWA boundary under the jurisdiction of the WIPP. A LUR consists of a narrative description of the project, a completed Environmental Review (ER) (Attachment 1 to Appendix B), and a map depicting the location of the proposed activity. The LUR is used to determine if applicable regulatory requirements have been met prior to approval of a proposed project. A LUR is submitted by any WIPP organization or outside entity wishing to complete any construction rights-of-way, pipeline easements, or similar actions within the WLWA and on lands used in the operation of the WIPP, under the jurisdiction of the DOE.

\subsection{OBJECTIVE}

The objective of this chapter is to describe the method that the DOE, working in concert with the WIPP Land Use Coordinator (LUC), will use to review and implement regulatory guidelines that govern land use activities related to the WLWA. The DOE is required by various DOE Orders, the consultation and cooperation agreement between the DOE and the State of New Mexico, MOUs, and regulations to evaluate activities that could impact human health or the environment prior to implementation.

\subsection{PLANNED ACTIONS}

The review and implementation of activity-specific regulatory requirements is initiated by a NEPA review of the activity. NEPA requirements are implemented through the WIPP NEPA Compliance Program. As described below, the ER is used to initiate regulatory reviews. Through the submittal of a LUR and an attached ER, the WIPP NEPA Compliance Coordinator evaluates potential environmental impacts, mitigating actions for the impacts, and potential permit requirements. ERs are evaluated to determine if air, water, hazardous waste, or land use permits are required for the activity. Potential impacts to wildlife and cultural resources are also included in the ER evaluation.

Discussions of environmental regulations that pertain to the WIPP Project are provided in the WIPP Biennial Environmental Compliance Report (BECR), and the WIPP 
Annual Site Environmental Report (ASER). Both documents, available from the LUC on request, provide regulatory compliance applicability and status for federal, state, and local environmental regulations. Land use requestors will find that the BECR and the ASER serve as reliable reference documents for use in better understanding regulatory requirements at the site. Both documents will assist the requestor in identifying regulations that could affect the development of project schedules prior to submittal of the LUR package (to include the ER). LUR submittals are reviewed in accordance with the flow diagram in Figure 2.1 of this document.

\subsubsection{National Environmental Policy Act and Land Use within Waste Isolation Pilot Plant Land Withdrawal Area}

\subsubsection{Waste Isolation Pilot Plant Project Requests}

LURs associated with WIPP-specific activities are addressed as follows:

1. The requestor will submit to the LUC (see foreword) a LUR (Appendix B) identifying the proposed project.

2. The LUC will provide the requestor with a guide for the proper completion of a LUR (Appendix B). The submittal of a properly completed LUR (containing a completed Environmental Review or ER) is mandatory for obtaining authorization for use of lands contained within the WLWA (excluding the inner Property Protection Area), or lands outside the WLWA boundary used for the operation of the WIPP, managed under the jurisdiction of the DOE (e.g., groundwater surveillance pads, railroad rights-of-way).

\subsubsection{Land Use Request Review Process}

1. The LUC will assign a unique number to the LUR and enter the LUR into a tracking system.

2. The LUC will review the LUR and transmit it, along with any supporting documentation, to the WIPP NEPA Compliance Coordinator for evaluation. The WIPP NEPA Compliance Coordinator will enter the LUR number into the computerized NEPA tracking database.

3. The NEPA Compliance Coordinator will evaluate the submitted LUR for impacts to human health and the environment using screening criteria defined by the CAO (e.g. DOE Order 541.1 NEPA Compliance Program) and comparing the proposal to activities evaluated within the WIPP's existing NEPA documents (e.g., WIPP's Final Supplement Environmental Impact Statement).

4. In consultation with appropriate cognizant regulatory personnel, the WIPP NEPA Compliance Coordinator will complete a technical review, as required, to address any concerns not completely addressed in the LUR. Items that need to be resolved prior to project initiation will be added to the review in order to 
comply with regulatory considerations such as waste minimization, water and air permit requirements, waste management, reclamation requirements, and rightsof-way, in addition to other concerns pertaining to the protection of human health and the environment.

5. The WIPP NEPA Compliance Coordinator review the proposed action against the approved screening criteria for such actions provided by the CAO.

6. If the proposed action is addressed by existing NEPA documentation and other pertinent regulatory approvals have been obtained, the WIPP NEPA Compliance Coordinator will indicate approval and return the package, including the LUR, to the LUC. Subsequently, the LUC may convene the LMC and advise the requestor of regulatory concerns.

7. If the ER is outside the scope of actions previously assessed within WIPP's NEPA documentation, the WIPP NEPA Compliance Coordinator will submit the LUR and ER to the CAO for consideration by the CAO's NEPA Compliance Officer.

8. The WIPP NEPA Compliance Coordinator will inform the requestor of the action of additional requirements for NEPA documentation and an estimated time frame for completion and follow $\mathrm{CAO}$ guidance for completion of subject documentation.

9. After the WIPP NEPA Compliance Coordinator has released the LUR (including the completed ER) back to the LUC with the appropriate level of NEPA approval, the LUC will log out the ER signifying the return of the ER to the requestor.

10. If any additional issues remain outstanding, the LUC will coordinate with the requestor to resolve the identified concerns.

11. When the requestor has addressed all concerns contained in the review satisfactorily, the ER, along with review resolution documentation, will be returned to the LUC.

12. The LUC will $\log$ in the returned request and indicate final approval of the proposal (this approval may contain contingencies for the implementation of the action, such as avoidance measures for cultural resource sites, etc.).

\subsubsection{Project Requests Through the Bureau of Land Management or State Land Office}

Requests for projects that involve land uses on BLM, state of New Mexico, and DOE lands will require a "lead agency" determination. Lead agency status regarding projects involving multiple agencies will be determined by existing MOUs (Appendix C) or 40 CFR 
1501.5. To this extent the following criteria are used to determine "lead agency" designation:

- Magnitude of respective agency's involvement

- Project approval/disapproval authority

- Expertise concerning the effects of environmental actions

- Duration of agency's involvement

- Sequence of agency's involvement

In the event the DOE receives lead agency designation, guidelines contained in the standards of Subsection 2.2.1 of this document apply.

If either the BLM or the State Land Office for the State of New Mexico is determined to be the lead agency, the LUR review process will be as follows:

1. The BLM or State will direct the requestor to notify the WIPP LUC prior to initiating subject land use activities.

2. The BLM or State Supervisory Realty Specialist (SRS) will oversee the submittal of the requisite EA, as appropriate, and advise the requestor to notify the WID LUC for guidance in the development and submittal of a LUR.

3. A Land Use Request (LUR) (Appendix B) will be submitted in writing to the Land Use Coordinator (LUC) (see foreword) for use of the land within the WLWA (excluding the inner Property Protection Area), or on lands outside the WLWA under the jurisdiction of the WIPP, by a non-WIPP organization.

4. The requestor will contact the BLM or the State Land Office regarding their proposed action.

5. The requestor will provide information to the lead agency to allow an environmental assessment (EA) to be prepared for the proposed project.

6. Upon completion of the draft EA, the BLM or state SRS will transmit the document, along with any supporting documentation, to the LUC for review and comment.

7. The LUC will assign a unique number to the LUR and enter the request for land use into the tracking system.

8. The LUC will review the ER and consult the cognizant WIPP NEPA Compliance Coordinator for environmental regulatory considerations.

9. The WIPP NEPA Compliance Coordinator will convey any regulatory consideration regarding the proposed action to the LUC by way of a technical review. 
10. The LUC will append the technical review with any other land use considerations he/she may feel proper and appropriate.

11. If the regulatory considerations detailed in the technical review are significant, the BLM or state SRS will arrange a meeting with the affected requestor. The requestor(s) will be advised of the regulatory concerns of the proposed action.

12. When all regulatory considerations are addressed to the satisfaction of all affected participants, the project may be approved by the DOE Carlsbad Area Office (CAO).

13. The DOE Land Manager will transmit a letter to the BLM or state SRS, approving the proposed project, and will send a courtesy copy to the WIPP LUC. 


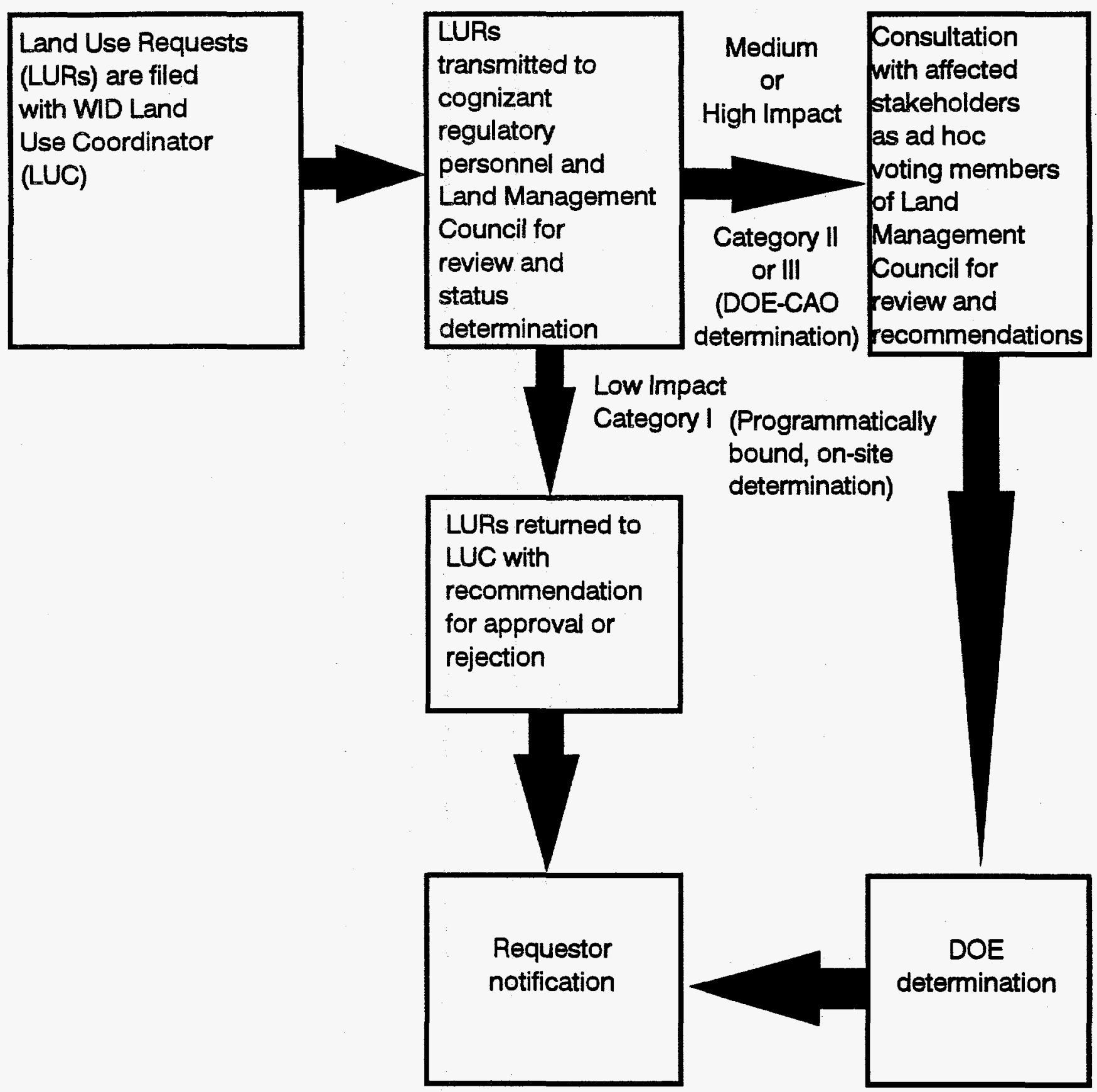

FIGURE 2.1 


\section{CHAPTER 3}

WILDLIFE 


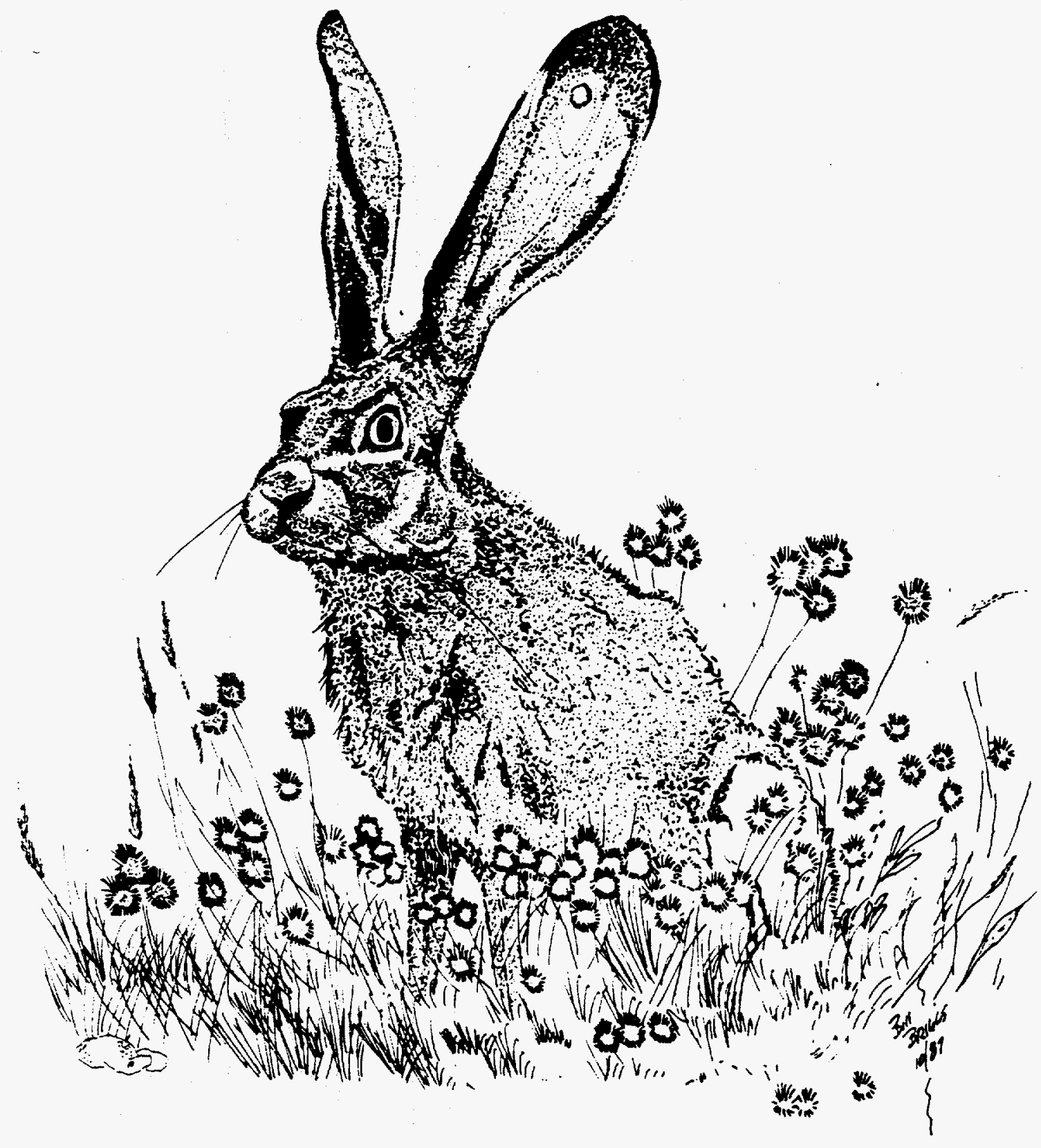




\section{CHAPTER 3 WILDLIFE}

\subsection{INTRODUCTION}

This chapter is dedicated to planning wildlife investigation and management projects. Recommendations for approaches, potential prospectuses, and proposed investigational plans are discussed. Tools, techniques, and personnel available for conducting investigations and achieving management objectives are examined. These criteria are essential to wildlife objectives for effective planning as it relates to choice, between alternatives, establishment of realistic constraints (e.g., time, funding, manpower), practicality, and expediency in the development of efficient research methodology.

Wildlife within the WLWA shall be given consideration during planning stages of projects involving the disturbance or encroachment of wildlife habitat inside DOE lands by way of the LUR process as described in Chapter 2, "Environmental Compliance." Monitoring and research of specific wildlife populations will occur in accordance with applicable laws, agreements, and regulations subject to funding and personnel constraints.

The WIPP conducts a number of general wildlife management activities. Each activity is mandated and/or supported by state and federal guidelines or by way of commitments created through interagency agreements (e.g., Raptor Research and Monitoring Interagency Agreement, Appendix E) and/or MOUs (Appendix C).

Examination of wildiife species in the area reveals significant diversity and complexity. Management of indigenous wildlife incorporates the development of a logical sequence when programming activities. Solutions for problems (e.g., home-range, territoriality of desert mule deer) will serve the implementation of conservation and resource management objectives as they pertain to the management and operation of the WIPP site.

\subsubsection{Affected Biological and Wildlife Environment}

The wildlife habitat around the WIPP is categorized in accordance with the BLM's standardized habitat sites subsequent to a detailed Integrated Habitat Inventory Classification System. WIPP lands comprise a small part of those lands grouped into major habitat types as described in Appendix L-2 of the East Roswell Grazing Environmental Impact Statement. Moreover, habitat types and species inventories were conducted for the DOE during initial site characterization studies as described in the WIPP Biology Program, the Final Environmental Impact Statement (FEIS) (DOE/EIS-0026-FS), the Site and Preliminary Design Validation studies, and the Environmental Monitoring Plan (DOE/WIPP 92-040). 
Wildlife in the vicinity of the WIPP is characterized by a wide variety of insects, amphibians, reptiles, birds, and mammals.

The Chihuahuan desert has long been regarded for its extraordinary diversity of plant and animal communities. The location of the WIPP, situated in the Los Medaños region of the Chihuahuan desert, exemplifies this unusual array of biotic factors. The Los Medaños is located in an area of intergradation between the northern region of the Chihuahuan Desert and the Llano Estacado or Staked Plains. The region is characterized by aeolian and alluvial sedimentation on upland plains that form hummocks, dunes, sand ridges, and swales with the presence of Havard Shin Oak (or shinnery oak) as a prominent foliar factor. Although the abundance of Shin Oak has aided in the stabilization of the dunes, a number of them remainunstable and exhibit distinct signs of shifting. An additional predominant shrub is Honey Mesquite which has invaded what at one time was a short-grass, shinnery oak-dominated landscape.

As with many areas, the shinnery oak community has shifted from a dominant bluestem/grama grassland with varying amounts of shinnery oak, sand sage, and yucca to a composition dominated by Dropseeds, three-awns, and Gramas, with high densities of Plains Yucca, annual forbs, and Mesquite.

According to the Bureau of Land Management's (BLM) Resource Management Plan (RMP), 15 percent of the wildlife species identified in the Resource Area utilize the Shin Oak habitat with 30 percent occupying areas consisting primarily of grass compositions with greater than 75 percent grasses in the description of the potential plant community.

The subtle blend of plant communities with Shin Oak/Dune habitat (SOD) that somewhat dominates Grassland (SG) affords a composition of factors that results in the diverse wildlife population of the Los Medaños.

Wildlife populations are characterized by numerous species of arthropods, amphibians, reptiles, birds, and mammals. Now and then, aquatic mollusks, inhabitants of local stock ponds and livestock drinking units, are observed. Jerusalem crickets (Stenopelmatus fuscus) are an example of one order of insects that occupy the locality of the WIPP.

Red-Spotted Toads (Bufo punctatus) and New Mexico Spadefoot Toads (Spea hammondi) are two examples of no fewer than ten different species of indigenous amphibians. Their significance is seldom recognized until spring or summer rains, at which time they appear in extraordinary numbers.

Reptiles comprise more conspicuous inhabitants due to the diurnal nature of numerous species. Ornate Box Turtles (Terapene ornata), Desert Side-Blotched Lizards (Uta stansburiana), and Texas Horned Lizards (Phrynosoma cornutum, a federal notice-of-review species listed under the Endangered Species Act) represent 3 of approximately 35 distinct species of indigenous reptiles. Moreover, three species of rattlesnake can be encountered in the area. 
Bird densities vary according to preferable food and habitat availability. The habitat heterogeneity of the Los Medaños accounts for a wide assortment of bird species that inhabit the area either as seasonal transients or permanent residents. Large numbers of Mourning Dove (Zenaida macroura), Pyrrhuloxias (Cardinalis sinuata), and Black-Throated Sparrows (Amphispiza bilineata) are frequently observed. A unique desert subspecies of the Northern Bobwhite (Colinus virginianus), Scaled Quail (Callipepla squamata), and an occasional Lesser Prairie Chicken (Typanuchus pallidicinctus) depict the gallinaceous inhabitants. Due to a scarcity of surface waters in the immediate vicinity of the WIPP, migrating or breeding waterfowl are not considered common.

The area supports a particularly abundant and diverse population of Raptors, or birds of prey. Harris' Hawks (Parabuteo unicinctus), Swainson's Hawks (Buteo swainsoni), and Great Horned Owls (Bubo virginianus) illustrate species commonly found nesting in the area. The density of large avian-predator nests has been documented as high as 16 nests per 10 square kilometers, one of the predominant raptor breeding populations in recorded scientific literature.

As is common in desert biomes, Black-Tailed Jackrabbits (Lepus californicus) and Desert Cottontails (Sylvilagus audoboni) are the most conspicuous mammals. Three species of Ground Squirrel (Spermophilus spp.) and numerous other rodents such as Kangaroo Rats (Dipodomys spp.) and Cactus Mice (Peromyscus eremicus) also occupy the area. Large piles of debris, that may consist of aluminum cans, cow dung and other rubbish (sometimes to a height of nearly five feet), clustered at the base of cactus or large mesquites characterize the houses (or "middens") of the Southern Plains Woodrat (Neotoma micropus). Although specimens rarely exceed weights of 300 grams, several Woodrats that weighed nearly 500 grams have been captured, by WIPP biologists, near the WIPP. Big-game species, such as Desert Mule Deer (Odocoileus hemionus) and carnivores such as Coyotes (Canis latrans) and Badgers (Taxidea taxis) also frequent the area.

The DOE consulted with the USF\&WS in 1979 to determine the presence of threatened or endangered species at or near the WIPP site. At that time, the USF\&WS listed the Lee Pincushion Cactus (Coryphantha sneedi var. leei), the Black-Footed Ferret (Mustela nigripes), the American Peregrine Falcon (Falco peregrinus anatum), and the Bald Eagle (Haliaeetus leucocephalus) as threatened or endangered that could occur on lands within or outlying the WIPP site. However, no critical habitat for endangered species was identified at the WIPP. In 1989, the DOE again consulted with the USF\&WS to update the list of threatened and endangered species. The agency has advised the DOE that the list of species provided in 1979 is still valid.

During 1989, the DOE consulted with the NMDG\&F regarding the state-listed endangered species in the vicinity of the WIPP. Based on NMDG\&F Regulation 657, dated January 9, 1988, the NMDG\&F listed seven birds and one reptile in one of two endangerment categories that occur or are likely to occur at the site.

During 1995, the USF\&WS transmitted the April 24, 1995, updated list of threatened and endangered species for Eddy and Lea Counties, New Mexico. Accordingly, the list was 
disseminated to pertinent WIPP departments for consideration and incorporation into applicable documents. The DOE currently operates under the assumption that activities associated with the operation of the WIPP will have no impact on any threatened or endangered species. Considerations pertaining to protected species are implemented in accordance with this management plan, during the deliberation and administration of projects conducted on WIPP lands.

\subsection{OBJECTIVES}

The objective of the DOE is to maintain and/or enhance the ecological condition of wildlife habitat within the WLWA.

Decisions regarding the management of wildlife on DOE lands are implemented over time in accordance with the DOE planning and budgeting processes. Priorities will be established for each management program to coordinate sequential implementation.

Implementation of wildlife management objectives shall be in accordance with existing local, state, and federal laws. In addition, it is the DOE's objective to comply with commitments contained in existing MOUs and interagency agreements with separate agencies and to consider the needs of, and the impacts to, native wildlife populations throughout the life of the WIPP (to include decommissioning).

\subsection{PLANNED ACTIONS}

\subsubsection{Raptors}

Investigation and management of the raptor resource of the Los Medaños, as it pertains to the WIPP, shall be conducted in accordance with the following:

1. The BLM and the DOE will continue the Raptor Research and Management Program in accordance with Interagency Agreement No. 1422G910-A2-0016 (Appendix E).

2. All land management actions involving intrusion into raptor habitat will take into consideration, prior to project approval, the potential impacts on raptor resources in the area. Documentation identifying potential impacts and proposed mitigation method will be submitted to the cognizant regulatory personnel (WIPP raptor biologist) for status determination (e.g., approval or denial). For example, power lines within the withdrawal will be constructed using acceptable configurations (e.g., BLM specifications) regarded as "raptor safe" by WIPP raptor biologists.

3. All raptor research will be conducted by personnel trained in the science disciplines and will be authorized under state and federal permits to conduct the desired studies. At such time that a study is determined to be counterproductive or too intrusive, it can be terminated, at the discretion of WIPP cognizant 
personnel, until such time that a complete evaluation and concurrent disclosure is conducted.

4. The DOE will solicit, contingent on funding, research proposals from educational institutions, non-profit organizations, environmental/scientific groups and/or state agencies (e.g. NMDG\&F) who desire to conduct raptor research in the area. These investigations will provide valuable data, function to expand the data gathering network, and project a positive public image for the WIPP by conveying to the general public the positive environmental impacts of the WIPP. Cognizant WIPP personnel (usually the Land Use Coordinator) will serve as supervisors to personnel conducting research and will evaluate research techniques to assess the impacts of the research on the resource. The LMC will reserve the right to suspend a study for evaluation, by the Land Use Coordinator, if evidence reveals that intrusive research activities are having a negative impact upon the environmental resource.

\subsubsection{Threatened and Endangered Species}

1. Upon identification of habitat within WIPP lands occupied by state or federally listed species, the area will be set aside, posted against unauthorized entry, and routinely monitored. Prior to implementation of proposed projects and/or other activities that may affect special status plant or animal species within the WLWA, expeditious notification (within 30 days of project implementation) of cognizant regulatory agencies (e.g., the NMDG\&F, the USF\&WS, the Energy, Minerals and Natural Resource Department's Forestry and Resources Conservation Division) will be conducted by WIPP personnel. The DOE will solicit recommendations from said agencies for incorporation into a habitat management plan to be developed and implemented in a timely manner.

2. Federally listed threatened and endangered (T\&E) plant and animal species are managed according to USF\&WS recovery plans. If a preliminary determination is made during the assessment process that a proposed project could affect $T \& E$ habitat, then consultation with USF\&WS will be initiated under Section 7 of the Endangered Species Act of 1973, as amended. State-listed species will be protected by way of cooperative agreements, joint powers agreements, or MOUs with the NMDG\&F, EMNRD Forestry and Resources Conservation Division, or other cognizant regulatory agencies.

3. The DOE will continue to monitor for the presence of T\&E species.

4. Cognizant WIPP personnel will continually monitor and maintain, as required, sensitive habitats for $T \& E$ species.

\subsubsection{Ungulates}

1. The DOE will initiate, contingent on funding and manpower, investigations designed to ascertain territories, home ranges, and migration trends of desert 
mule deer (Odocoileus hemionus). Evaluations of desired food sources by season would benefit WIPP biologists by way of aiding in the determination of seed mixes conducive to the preferences of the local deer herd. Suitable mixes will then be used in reclamation plans.

2. As constraints associated with funding, manpower, and permitting allow, the WIPP will provide monitoring studies into the life histories of wild desert ungulates. These may involve the radio-tagging of deer to evaluate WIPP effects on transient populations. Moreover, this approach would allow scientists to determine the status of the local population pertaining to home-range parameters and migratory movements in response to seasonal activity, livestock forage, and oil and gas exploration.

3. New water developments within the WLWA will be made accessible to wild ungulates. Existing water developments (e.g., livestock watering units) inside the WLWA will be modified (if necessary) to accommodate wildlife needs.

4. Fencing within the WLWA will reflect configurations recommended by the BLM for construction in areas containing wild ungulates.

\subsubsection{Small Game}

\subsubsection{Galliformes}

1. The DOE will implement, contingent on funding and manpower, analyses into the dynamics of the desert galliforme (quail and prairie chickens) populations. Examination of food preferences, distribution, range, and breeding behavior will be incorporated into the research design.

2. Galliformes, particulariy desert quail, comprise one of the more popular recreational pursuits of local hunters and therefore represent a direct pathway to man for environmental contaminants. Available information regarding the life histories of native quail (e.g., scaled quail and desert subspecies of bobwhites) are finite, thus affording WIPP scientists limited parameters for scientific inquiry and management designs. Due to their popularity with sport hunters and their capacity as bioindicators for WIPP radiological analyses, desert quail will be considered a priority for research as funding is made available.

3. New water development within the WLWA will be equipped to facilitate desert galliformes (e.g., bird ramps in livestock waterers). Existing water developments will be modified to facilitate desert galliformes.

4. Reclamation seed mixes will reflect plant species conducive to the needs of native gallinaceous birds.

5. Population densities of the lesser prairie chicken will be determined to assess the need for mitigation actions associated with surface-disturbing activities. 
Location and status of booming grounds, or "leks," will be identified each spring. Active leks will be monitored passively to preclude inadvertent disturbances associated with the operation of the WIPP or by members of the general public.

\subsubsection{Nongame Species}

\subsubsection{Small Mammals}

1. Small mammal population studies will continue as appropriate, with regards to, the WIPP nonradiological environmental sampling protocol as defined in the Annual Site Environmental Report (DOE/WIPP 95-2094).

\subsubsection{Furbearers}

1. Persons wishing to conduct trapping activities within the WLWA shall, at minimum, notify the WIPP Land Use Coordinator (for permission to trap) and the WIPP security force for a briefing regarding safety requirements and conduct while operating on WIPP lands. Trapping of furbearers in the WLWA will be allowed, however, restrictions will apply. Trapping will be done in accordance with all applicable state and federal laws. Traps shall be well-marked and checked every 24 hours at a minimum. If the presence of traps represents a safety concern, or if the trapper has not complied with stipulations imparted by cognizant WIPP personnel, the traps will be removed immediately. If the presence of traps is determined to be unnecessary by the WIPP LUC, all traps will be removed until such time that the WIPP LUC, in consultation with the LMC and the proper authorities, concludes that trapping may resume.

2. Resident populations of furbearers (e.g., coyotes, foxes, bobcats) will be monitored on an "as needed" basis. Responses to anomalous conditions (e.g., disease) in the furbearer population will be contingent on the severity of the condition (e.g., rabies) and the potential threat it represents to the employees of the WIPP.

3. The deployment of traps utilizing poisons such as cyanide (e.g., M-44s), are strictly prohibited on WIPP lands.

\subsubsection{Small Birds}

1. WIPP personnel will continue to survey resident and transient populations of small birds (e.g., Passeriformes) on an "as needed" basis. Migration trends, habitat preferences, and nesting behavior will be factored into mitigation actions concerning adverse impacts of WIPP operations on protected species.

2. Reclamation efforts will use plant species conducive to the needs of small birds. 
3. Water developments and similar hazards (e.g., molasses troughs) within the WLWA will be configured to prevent mortalities of small birds.

4. If the determination is made that the nest of a protected species compromises the normal working operation of the WIPP (e.g., nests built on construction machinery), cognizant WIPP personnel will contact appropriate regulatory agencies (NMDG\&F, USF\&WS) for guidance regarding response protocol. Nests will remain in place and undisturbed until the determination of legal response protocol.

\subsubsection{Reptiles}

1. The monitoring and management of reptiles will fall primarily under the auspices of T\&E management. As of 1993, the area around the WIPP was identified as having habitat favorable for the inhabitation of the Dune Sagebrush Lizard (Sceloporus arenicolous), a state-listed species. Moreover, contacts with Texas Horned Lizards (Phrynosoma cornutum), a federal notice of review species, are not uncommon on WIPP lands. Therefore, potential impacts to these protected species will be considered during deliberation of land management decisions.

2. All construction projects conducted on WIPP lands will take action in accordance with all applicable state and federal laws pertaining to the mitigation of impacts to habitat conducive to the presence of protected species of reptiles. 
CHAPTER 4

\section{CULTURAL RESOURCES}




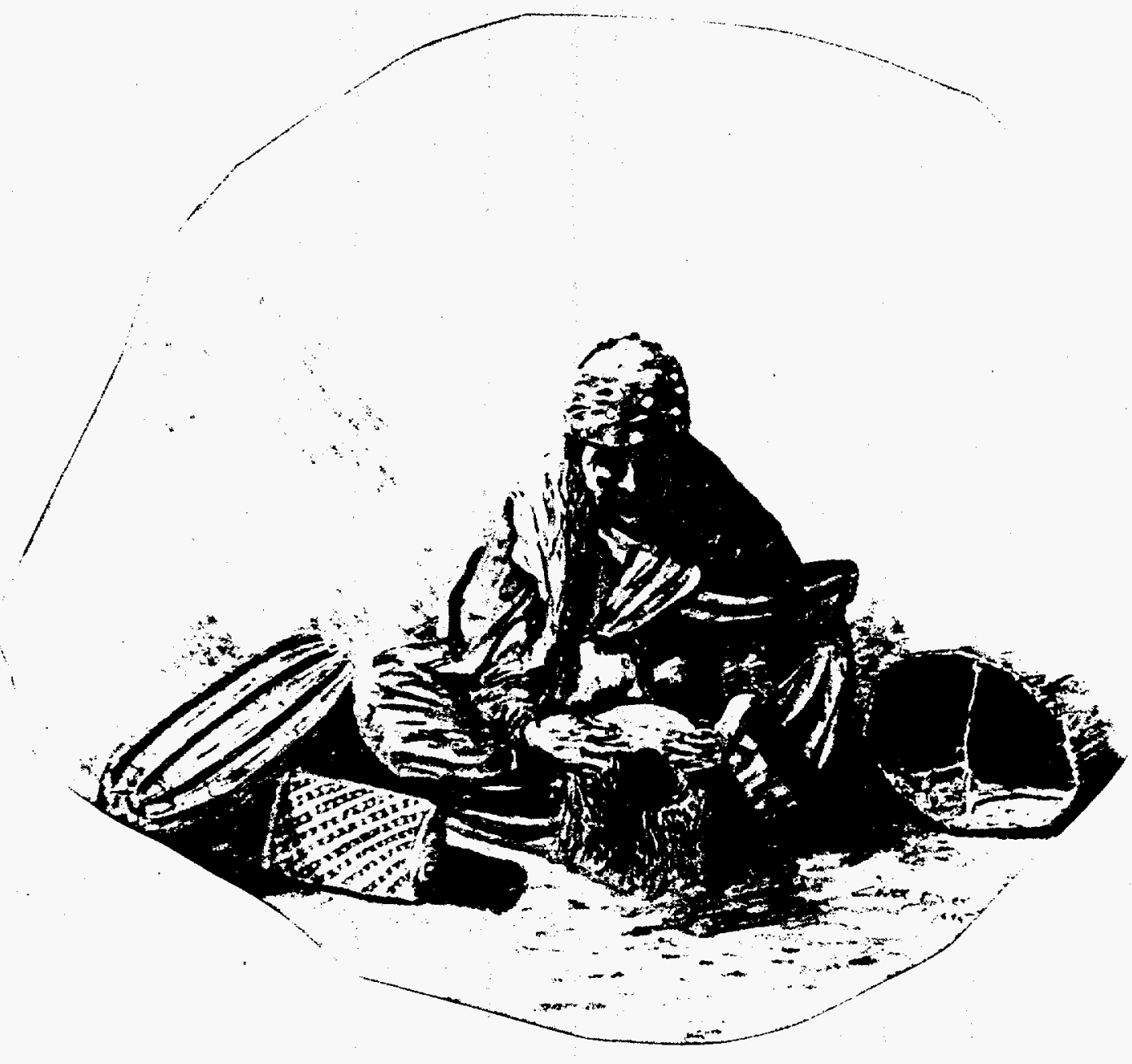




\section{CHAPTER 4}

\section{CULTURAL RESOURCES}

\subsection{INTRODUCTION}

This chapter provides edicts pertaining to the appraisal, documentation, protection, preservation, and chronology of archaeological and historic resources within the 16-section WIPP Land Withdrawal Area. The BLM's Carlsbad Resource Management Plan (RMP) is used as guidance for the management of the cultural resources.

\subsubsection{Cultural Resources in the Affected Environment}

From man's first arrival in the Southwest about 10,000 B.C. to the late 1800 s, southeastern New Mexico was inhabited by aboriginal hunters and gatherers who subsisted on various wild plants and animals. These people would have found a number of edible plants throughout the region, including mesquite beans, hackberries, walnuts, acorns, seedproducing grasses, agave and a variety of other succulents. Big and small game, including bison, deer, antelope, rabbits, reptiles, birds, and various invertebrates, could have been hunted or collected in the region.

From approximately 600 A.D. onward, as trade networks were established with Puebloan people to the west, domesticated plant foods and materials, including corn (or maize), beans, squash, and cotton, were acquired in exchange for dried meat, hides, and other products from the Pecos Valley and Plains. The indigenous population may also have practiced horticulture at favorable locales in the area, but only on an intermittent basis, since water for crops would have been scarce and unpredictable much of the time.

In the mid-1500s, the Spanish Conquistadors encountered Jumano and Apachean peoples in the region practicing hunting and gathering and engaging in trade with Puebloans. Later, as the natives acquired horses, and as Europeans began settling the land, this traditional way of life evolved into specialized bison hunting on the Llano Estacado and raiding both Spanish and Puebloan settlements to the west. In the late 1800 s, the region was settled by ranchers and farmers.

The WLWA is situated in dune-covered, rolling-plains terrain in the eastern part of the BLM's Carlsbad Resource Area. Known archaeological sites within the area are primarily the remains of prehistoric camps and short-term settlements. These localities are generally marked by hearth features, scattered burned rock, flaked stone projectile points, and cutting and scraping tools, pottery fragments, and groundstone implements. Locations generally represent short-term, seasonal occupations by small, nomadic groups of hunters and 
gatherers who utilized the plants and animals in the dune lands east of the Pecos River. In a few cases within the WLWA, sites with evidence of structures have been reported. These sites probably hosted occupations of perhaps several weeks or months.

Many known historical sites in southeastern New Mexico consist primarily of early twentieth century homesteads that failed, or isolated features from late nineteenth and early twentieth century cattle or sheep ranching and military activities. Although the region was part of the Spanish and Mexican colonial empires, no related conquest or settlement sites have yet been identified.

Historic components (more than 50 years old) are rare, but are occasionally noted within the WLWA. These include features and debris related to ranching in the early years of the twentieth century. In addition, more modern ranching debris and facilities such as fence lines are present in the area, including some which are likely still in use. Ranchrelated sites which date to the 1940s and 1950s are common in parts of the WLWA. These will be considered historical properties within the next several years and under current law, will have to be treated as such. The majority of the several sites recorded in the area typically include elements which can contribute to their eligibility for the National Register of Historic Places. With few exceptions, cultural properties known or anticipated for the WLWA are significant; they must be identified, recorded, assessed through inventory, and considered in any plan of development for the area.

Compared with most other parts of southeastern New Mexico, the locations and nature of cultural resources within the WLWA can be described relatively well, based on intensive inventory of portions of the area, along with limited excavation and some other work on some sites.

In 1976 four sections comprising the WIPP core area (Sections 20, 21, 28, and 29), along with associated rights-of-way and drilling pads within and outside the WLWA (Nielson 1976, Linnabery 1976) were inventoried by the Agency for Conservation Archaeology (ACA) of Eastern New Mexico University. Additional rights-of-way within and outside the WLWA were inventoried in 1978 and 1979 by ACA (Schermer 1978; MacLennan and Schermer 1979). Sites identified in the core area were relocated and evaluated in 1980 by ACA, and management recommendations for those sites were prepared (Schermer 1980). Subsequently, in accordance with the ACA's recommendations, a number of sites within the WIPP core area were tested for eligibility and/or were excavated as mitigation (Hicks 1981a; 1981b; Lord and Reynolds 1985).

In 1987 Mariah Associates conducted an intensive study of portions of 45 sections surrounding the WIPP facility. Mariah's study included an inventory of 2,460 acres in 15 quarter-section units. Inventoried units were selected so as to be representative of the area as a whole. Within each of the sample units, all cultural resource sites encountered were recorded, certain selected sites were tested, and management recommendations were prepared (Mariah Associates, 1987).

Between 1989 and 1992, several seismic projects associated with oil and gas development provided cultural resource clearances within the WLWA. Numerous inventories 
have been conducted outside the withdrawal area, primarily for oil and gas exploration and ranching.

Inventories conducted to date within the withdrawal area have located 59 archaeological sites, along with 91 isolated occurrences (single or few artifacts, or isolated features which can be fully recorded in the field). Sites and isolates identified are almost exclusively prehistoric. Only one site with both prehistoric and historic components has been noted.

Of a total of 10,240 acres in the WLWA, 3,380 acres ( 37 percent) have been inventoried for cultural resources. The results have been the discovery of one site for every 65 acres surveyed, and one isolate in every 42 acres. Based on this information, and assuming environmental homogeneity and a fairly even distribution of sites, the remaining 6,410 uninventoried acres could contain approximately 99 sites and 153 isolates. The combined results of the several inventories conducted within the WLWA compare well with those from Mariah's 1987 inventory of selected units over a much larger area. Mariah's results show only a slightly higher frequency of cultural resources per acre. In 2,460 acres, 40 sites and 75 isolates were recorded, or one site for every 62 acres and one isolate in every 33 acres.

Of the 40 sites identified and evaluated on the Mariah inventory, 14 appear to be eligible for the National Register of Historic Places, 24 are potentially eligible, and two are not eligible. [Note: A determination of eligibility can be made only after the site has been archaeologically tested.] None of the 75 isolates are considered eligible. While the data from the various researchers cited above are not always consistent with Mariah's explicit data on site significance, it appears that within the WLWA, the majority of sites either are or have the potential to be eligible for the National Register of Historic Places and will require consideration in future land disturbing activities.

Site significance is contingent on the number of manifestations encountered, their diversity in composition, the total number of each type of manifestation, and existing evidence suggesting whether or not a given site is datable. Previous limited cultural inventories indicate that the WLWA represents a potentially significant cultural resource contributor to the discipline of archeology and shall be regarded as such when deliberating land management decisions.

\subsection{OBJECTIVES}

The objectives of the DOE are to protect and preserve representatives of the full array of cultural resources, within the WLWA, for the benefit of scientific and socio-cultural use by present and future generations. "This guidance will ensure that cultural resources are given full consideration in land use planning and management decisions.

Planning/management policies pertaining to cultural resources within the WLWA shall be conducted in accordance with guidelines established in Appendix $G$ of this plan. 


\subsection{PLANNED ACTIONS}

The DOE will be responsible for completing cultural resource clearances for DOEfunded activities prior to initiating projects that result in land disturbance by means of the LUR process (see Chapter 2). Cultural resource clearances for actions by outside agencies or organizations, not funded by the DOE, but completed on DOE property, or crossing DOE property, are the responsibility of the outside agency or organization. Clearances will be completed in accordance with DOE standards, to include the guidelines established in this plan, and submitted to the DOE for review.

\subsubsection{Cultural Resource Management}

The DOE will continue to inventory, evaluate, and manage cultural resources inside the WLWA. In locating, evaluating, and adding properties to the management inventory, the DOE shall consult the Secretary of the Interior's Standards and Guidelines for Identification and Evaluation.

\subsubsection{Field Surveillance}

The WIPP will conduct field surveys in a timely manner relative to agency planning and LURs involving surface disturbance of land within the WLWA. The DOE shall select appropriate strategies to ensure that surveys are completed so that the DOE can carry out its responsibilities under Section 106 of the National Historic Preservation Act and 36 CFR 800, "Protection of Historic and Cultural Properties," before initiating any activity that might damage or disturb historic properties.

\subsubsection{Reports on Survey Results}

The DOE will provide reports on survey results, both negative and positive, fully documenting the rationale for decisions made in the identification and evaluation of properties. The inclusion of negative data--that is, data on surveys that result in the identification of no historic properties--is important to ensure that redundant surveys will not be performed in the future. Negative data are also needed to improve the reliability of predictive models. When large-scale surveys are conducted within the WLWA, or smaller scale surveys over time result in the accumulation of substantial bodies of survey data about cultural resources within the WLWA, the DOE will prepare reports synthesizing and analyzing the resulting data for use by interested scholars as well as for management purposes. Such analyses should be provided to the State Historic Preservation Officer (SHPO) and other interested parties for review, comment, and incorporation into inventories. The DOE will document current locations and conditions of artifacts, document records, and remains related to historic properties under their jurisdiction or control. In some cases, such as when objects have long been removed from their places of origin, documentation may not be feasible. Documentation should be included as appropriate in identification and evaluation records as well as National Register property records. 


\subsubsection{Report Reviews}

The DOE will provide reports to the State Historic Preservation Officer (SHPO) and other interested parties for review, comment, and incorporation into statewide historic resource inventories and for use in reviews under Section 106 of the National Historic Preservation Act when applicable. Such reporting to the state assists the state in maintaining comprehensive inventories while ensuring that state and DOE efforts are coordinated and compatible.

\subsubsection{Potentially Eligible Properties}

While conducting surveys, the DOE may encounter properties which are potentially eligible for the National Register (for Historic Places), but which do not meet the criteria at the time of the survey. For example, properties may be less than 50 years old and not of exceptional significance, consequently they would not meet the National Register criteria. If the LMC makes a determination that such properties are likely to become eligible in the future, it is to the DOE's advantage to document them at the time of the survey to facilitate later evaluation and registration. As cultural resources are identified, they will be evaluated in consultation with the New Mexico State Historic Preservation Officer (SHPO) and the BLM to determine their eligibility for listing on the National Register of Historic Places.

Sites which are found to be eligible for listing in the National Register of Historic Places will be avoided to the maximum extent possible. Where avoidance is not possible, mitigative measures designed to treat the effects of the undertaking will be developed and implemented in consultation with the SHPO and the BLM.

\subsubsection{Project Clearances}

Any proposed activity involving surface disturbance within the WLWA that has not received archaeological clearance from the LMC will be postponed until such time that an appropriate archaeological investigation is completed and approved.

\subsubsection{Management and Record Inventory}

The WIPP will create a management inventory and maintain records of identification, using appropriate forms as described in the "Guidelines for Federal Agency Responsibilities" under Section 110 of the National Historic Preservation Act, to include:

1. Description of methods used

2. Identification of lands inspected with data on all properties, both historic and nonhistoric -

3. Identification of evaluation methods

4. Identification of sources (informants)

5. Documents produced during research and consultation 


\subsubsection{Information Disclosure}

The DOE will establish guidelines for withholding and disclosing sensitive information regarding locations or character of historic or archaeological properties if it is established by the LMC, in consultation with cognizant professionals, that such disclosure may create a substantial risk, harm, theft, or destruction of such properties. Protocol for restricting information disclosure will be in accordance with the National Register Bulletin 29, "Guidelines for Restricting Information on the Location of National Register Properties." 
CHAPTER 5

GRAZING 


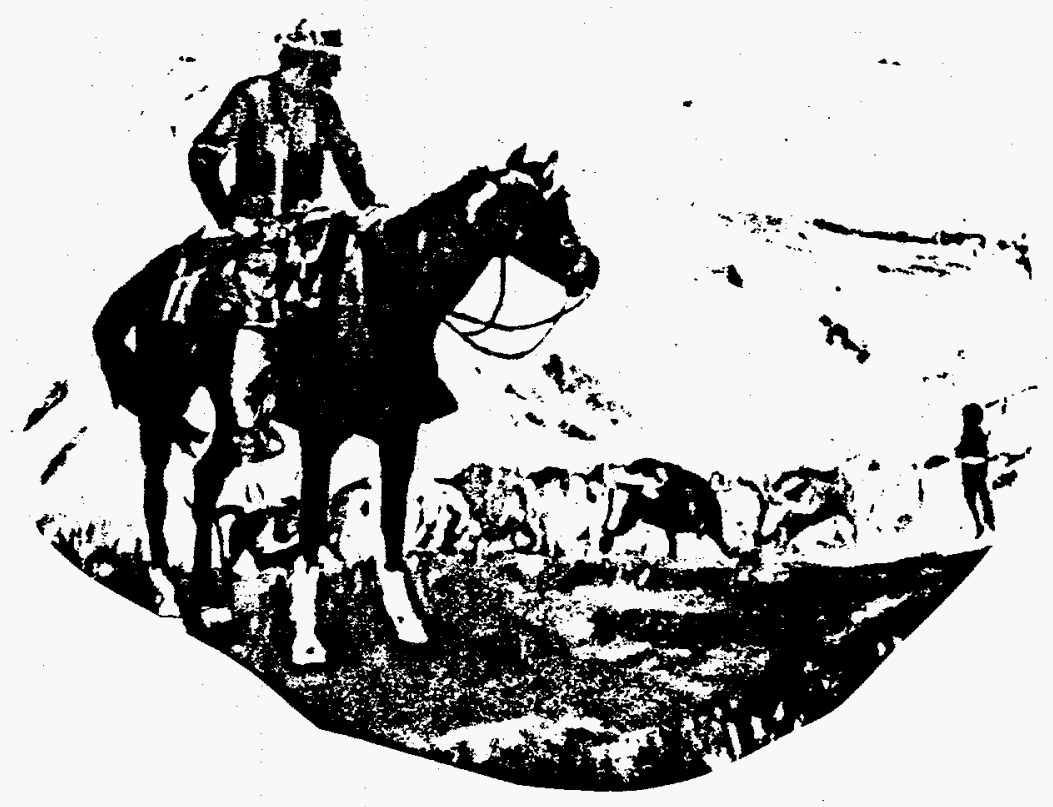




\section{CHAPTER 5 GRAZING}

\subsection{INTRODUCTION}

This chapter provides guidance pursuant to best management practices of the DOE, on lands contained in the WLWA, as they pertain to traditional livestock use. Grazing within the WLWA operates within the authorization of the Taylor Grazing Act of 1934, the FLPMA, the Public Improvements Rangelands Act of 1973, and the Bankhead-Jones Farm Tenant Act of 1973. The responsibilities of the DOE include supervision of ancillary activities associated with grazing (e.g., wildlife access to livestock water development, assurance that all livestock water developments inside WIPP lands are configured according to regulatory requirements, etc.) and maintenance of an interface with respective allottees. Administration of grazing rights shall be in cooperation with the BLM in accordance with existing MOUs (Appendix C) and the coinciding statement of work (Appendix D) through guidance established in the East Roswell Grazing Environmental Impact Statement (BLM 1979).

\subsubsection{Grazing within the Affected Environment}

The Land Withdrawal Act provides for the continuation of grazing practices, within the WLWA, in accordance with applicable grazing laws and policies, including: the Act described as "An Act to stop injury to public grazing lands by preventing overgrazing and soil deterioration, to provide for their orderly use, improvement, and development, to stabilize the livestock industry dependent upon the public range, and for other purposes..." approved June 28, 1934 (43 U.S.C. 315 et seq., commonly referred to as the Taylor Grazing Act); title IV of the Federal Land Policy and Management Act of 1976 (43 U.S.C. 1751 et seq.); and the Public Rangelands Improvement Act of 1978 (43 U.S.C. 1901 et seq., and 43 CFR 4100).

The principles of multiple-use and sustained-yield are basic to the management of this program. Rangelands comprise a substantial portion of the WLWA and provide forage for livestock and valuable wildlife habitats.

The WLWA affects two grazing allotments administered by the BLM: the Livingston Ridge (No. 77027) and the Antelope Ridge (No. 77032) (Figure 13.1).

The Livingston Ridge allotment begins 17 miles east of Carlsbad, New Mexico. The allotment is comprised of 55,581 acres in size and permitted to a livestock rancher operating a year-round cow/calf business. Land ownership is divided between federal, state, and private lands. Acreage distributed by ownership are as follows: (1) 41,608 acres of Federal 
ownership (2,880 acres within the WLWA), (2) 13,063 acres of State Trust lands, and (3) 910 acres of private (deeded) land. Although the allotment is 55,581 acres in size, only 5.18 percent of the allotment is situated within the WLWA.

Pasture rotation with some of the pastures being rested for at least a portion of the growing season, is standard management practice for this allotment. Vegetative monitoring studies to collect data on the utilization of the land, and the amount of precipitation by pasture from each study allotment are conducted annually to compare production with consumption. Should vegetative monitoring studies indicate a need for an allotment management plan, a plan will be developed in consultation with the BLM. The allotment is permitted for 6,483 Animal Unit Months (AUMs), which converts to 6.3 acres per AUM. (An AUM is the amount of forage necessary for the sustenance of a cow, or its equivalent, for a period of one month.)

The Antelope Ridge allotment begins 23 miles east of Carlsbad, New Mexico, and contains 77,574 acres. This allotment is permitted to a livestock rancher operating a yearround cow/calf business. Approximately 300 acres (more or less) within the Antelope Ridge allotment contain the WIPP facilities and are posted against trespass (see Chapter 10 Security for sector designations) and fenced to prevent grazing. Land ownership of the subject allotment is divided between federal, state, and private (deeded) lands. Acreage distributed by ownership are as follows: (1) 66,757 acres of federal land (7,360 acres within the WLWA), (2) 8,749 acres of State Trust lands, and (3) 2,068 acres of private land. Of the 77,574 acres contained in this allotment, 9.49 percent is within the WLWA.

An allotment management plan has been developed for this allotment by the BLM. The plan includes a seven-pasture rotation system, with some pastures being rested for full years and others receiving growing season rest. The allotment is permitted for 13,236 AUMs which translates to 7.0 acres per AUM.

Both allotments consist of sandy and deep sand range sites. These sites have combined shin-oak/dune (SOD) and grassland (SG) aspects and include grasses such as Gramas (Bouteloua spp.), Bluestems (Andropogon spp.), and Dropseeds (Sporobolus spp.). Other key forage plant species include Havard Shin Oak (Quercus havardii) and Fourwing Salt-bush (or Chamiza) (Atriplex canescens).

\subsection{OBJECTIVES}

The objective of the DOE for grazing management is based on the current practices for adjacent public lands. Priorities involve maintaining rangeland resource values on a longterm, sustained-yield basis utilizing vegetative monitoring studies of key forage species as the mechanism by which the need for any potential range management changes would be detected. 


\subsection{PLANNED ACTIONS}

Planned Actions will be administered by the BLM, for the DOE, in consultation with the State of New Mexico and affected county, state, and federal agencies.

\subsubsection{Grazing Regulations}

The DOE will continue to grant livestock grazing privileges in accordance with historical land uses as regulated by pertinent laws, regulations, and existing agreements (e.g., BLM/DOE MOU) governing livestock use of public lands.

Vegetative monitoring will continue in the WLWA to determine if the goals and objectives of the grazing allotments are being achieved. As a minimum, data on actual livestock use, wildlife use, degree of utilization of key forage species, climatic conditions, and rangeland ecological condition and trend will be collected.

\subsubsection{Configuration of Rangeland Improvements}

As a result of the WIPP Land Withdrawal Act, all existing and future rangeland improvements (e.g., livestock water developments) within the WLWA belong to the DOE. Therefore, all rangeland improvements within the WLWA will conform with configuration requirements established by the LMC and cognizant regulatory personnel.

New or replacement livestock watering units may have water supplied from the Double Eagle Water System. For connections to the Double Eagle Water System, the allottee will be required to meet the requirements identified in the water line contract with the city of Carlsbad as identified in Subsection 8.2.6.3 of this document. Request submittals will be routed in accordance with Chapter 2 and Appendix B of this document.

\subsubsection{Wildlife Access}

All rangeland improvements within the WLWA will be made accessible to wildlife. Any improvement that is determined by cognizant personnel to pose an imminent threat to wildlife of the area will be corrected immediately by the responsible party/parties or will be expeditiously removed from service at the expense of the responsible party/parties.

\subsubsection{Future Rangeland Improvements}

Future rangeland improvements will be initiated through a request to the BLM by the responsible party (requestor). The request will be forwarded by the BLM to the DOE for evaluation by the LMC. The LMC will determine the expediency of the request, make status decisions per the request, and attach necessary stipulations to the request. All requests for rangeland improvements will be completed in accordance with existing MOUs or comparable documents. LMC decisions will be sent to the BLM for incorporation into their response to the requestor. Decisions of the LMC are final and subject to amendment only at the discretion of the LMC. Stipulations (e.g., identification of party/parties responsible for the 
installation and/or maintenance of subject improvement) requested by the LMC shall be addressed to the satisfaction of the LMC by the requestor prior to implementation of the request.

\subsubsection{Maintenance of Existing Improvements}

General maintenance of existing rangeland improvements will be the responsibility of the allottee unless otherwise directed by authority of the LMC. All maintenance will be conducted in accordance with all applicable laws and regulations governing the respective action.

\subsubsection{Violations of Existing Agreements}

Alleged violations of existing agreements (e.g., MOUs), commitments, and/or existing laws and regulatory requirements will be brought before the LMC for discussion, determination, and resolution. Examples of violations are connections to water developments that do not meet configuration requirements pertaining to existing regulations and/or laws, and fence configurations that do not meet existing requirements and/or laws.

\subsubsection{Nonconformance with Grazing Requirements}

If evidence suggests that a respective allottee is in nonconformance with existing grazing regulations/requirements on WIPP lands (e.g., exceeding legal AUM allocation), the concern will be submitted, in writing, to the BLM for resolution. Final resolution will be done in consultation and cooperation with the $\mathrm{LMC}$.

\subsubsection{Modifications to Improvements}

Modifications of existing rangeland improvements (e.g., fence line alterations) may be conducted by the respective allottee. However, the modification will not contradict the management goals and best management practices of the BLM and the WIPP LMP. Requests for modifications must be submitted in writing by the respective allottee to the BLM. The BLM will forward the request to the DOE for review, comments, and determination by the LMC.

\subsubsection{Amending Grazing Rights}

If the determination is made by the LMC that livestock grazing represents a significant risk to the health and/or safety of WIPP personnel, the integrity of critical T\&E or wildlife habitat, or that it poses a risk to the incorporation of best management practices by the LMC, ancillary restrictions and/or guidelines may be imposed on the respective allottee pursuant to their grazing privileges on WIPP lands. If the determination is made by the BLM that a respective allottee has committed three or more incidents of noncompliance pertaining to existing grazing laws and/or restrictions, grazing privileges may be revoked within the WLWA, at the discretion of the LMC, in accordance with all applicable laws and regulations governing the revocation of grazing rights on public lands. 


\subsubsection{State Notification}

The DOE will provide notice to the EMNRD Forestry and Resources Conservation Division upon receipt or development of:

1. Grazing management changes and/or plans proposed for the WLWA;

2. Any report generated from the BLM's and/or DOE's vegetative monitoring program covering the WLWA.

\subsubsection{Grazing Fees}

Administration of grazing fees shall be conducted in accordance with the provisions of the BLM/DOE MOU (Appendix C). 



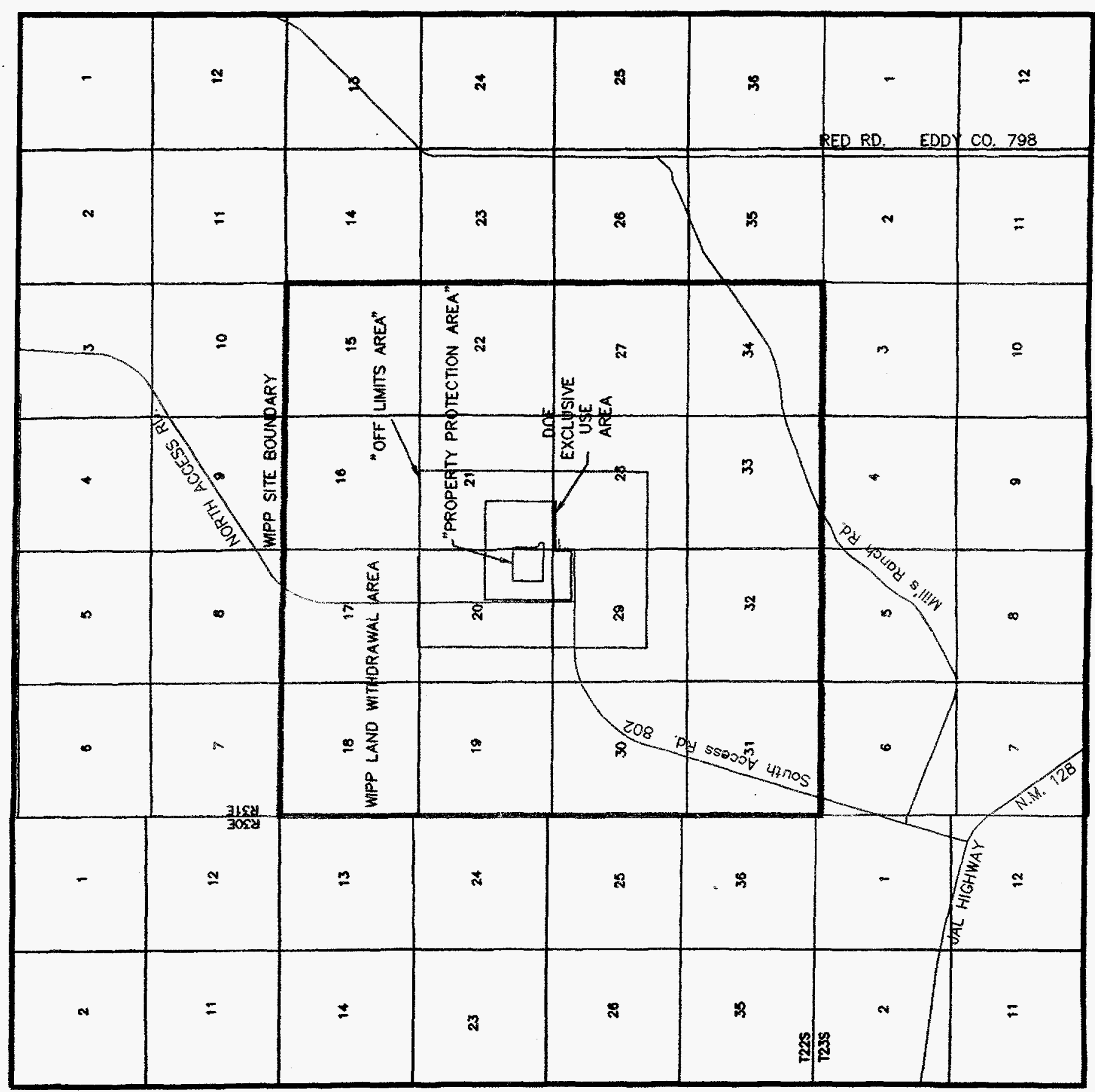




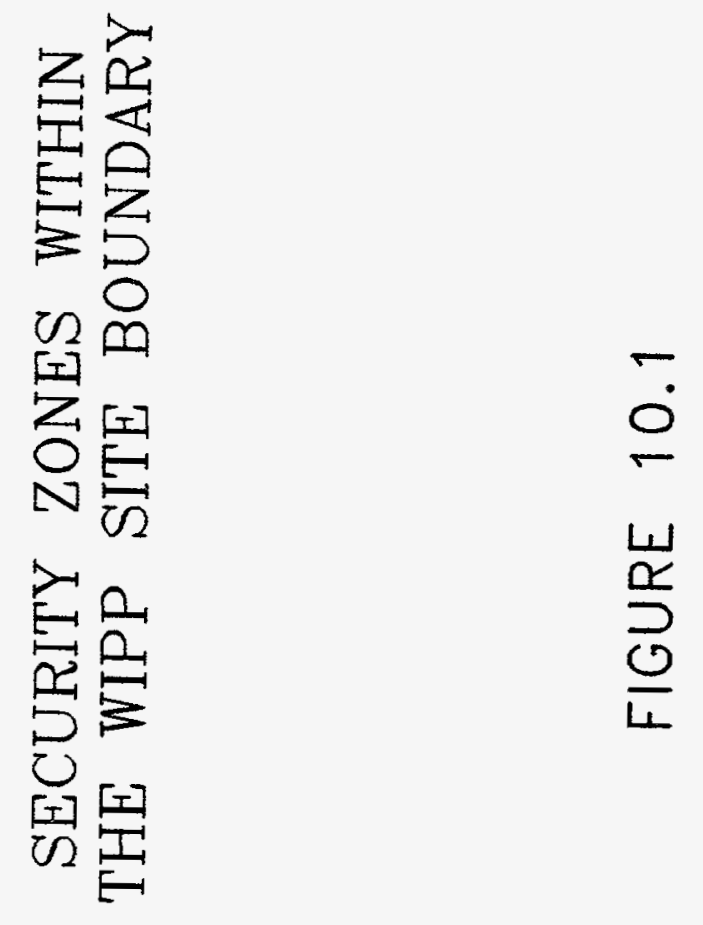

$=$
$=$

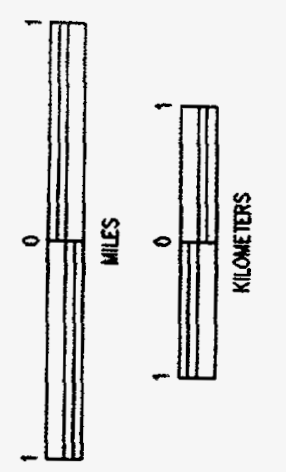




\section{CHAPTER 6}

RECREATION 


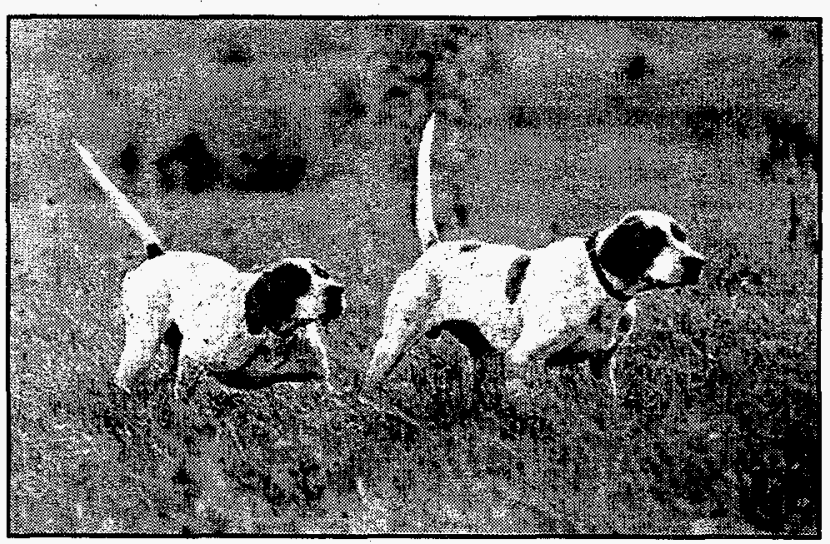




\section{CHAPTER 6 RECREATION}

\subsection{INTRODUCTION}

Recreational opportunities will continue in accordance with most traditional land uses. Examples of such land use concepts can be found in the Carlsbad Resource Area Resource Management Plan and Environmental Impact Statement (BLM-NM-PT-86-004-4410). Traditional land uses that conflict with the mission of responsible land management practices can be restricted on WIPP lands at the discretion of the DOE in consultation with the LMC and affected stakeholders. Properties posted with DOE "no trespassing" signs are excluded from public use and will be patrolled by WIPP security personnel to prevent unauthorized use. Violators are subject to prosecution in accordance with applicable laws and regulations governing property protection.

\subsubsection{Recreation within the Affected Environment}

Due to the topography, climatic conditions, and wildlife in the area of the WIPP site, an extensive (non-facility based) variety of recreational opportunities are available to include: hunting for both big and small game animals; camping; horseback riding; hiking; watching wildlife (e.g., bird watching); and sightseeing. The WIPP area contains significant biodiversity (see Chapter 3 Wildlife) in addition to historic and prehistoric sites (see Chapter 4 Cultural Resources). These offer rewarding opportunities for scientific study and interpretive recreation.

\subsection{OBJECTIVES}

The objective of the DOE is to support a range of recreational outdoor activities for all segments of the public, commensurate with demand, access, safety, regulatory requirements, environmental protection, and liability. Visitors have a freedom of choice with minimal regulatory constraint regarding activities outside the boundary of the "Off Limits Area". 


\subsection{PLANNED ACTIONS}

\subsubsection{Access}

Roads used in the operation of the WIPP are maintained and open to public access, unless otherwise designated. [Note: Roads posted with stipulations denoting alternate designations will be managed in accordance with the posted restrictions.] Roads within the WLWA will enhance recreational opportunities and allow use of WIPP lands. Areas identified as SMAs (e.g., reclamation areas, wildlife habitat) can, at the discretion of the LMC, be removed from access. These areas will be barricaded and/or posted accordingly to prevent unauthorized access.

\subsubsection{Off-Road Vehicles (ORVs)}

Management of roads and trails within the WLWA is conducted under requisite restrictions. This means that recreational motor vehicle use can be limited or prohibited at certain times, in certain areas, and/or for certain specified purposes to protect the health and safety of the public, environmental quality of the area, or for the common defense and security of the site. These restrictions generally apply to the following:
a. Numbers of vehicles
b. Types of vehicles
c. Time or season of use
d. Permitted or licensed vehicle use only
e. Use of existing roads and/or trails
f. Vehicle use in designated areas (roads/trails)
g. Other restrictions as deemed necessary

The use of ORVs within the WLWA will be limited to existing roads. Exceptions are those projects which are in conjunction with WIPP-related activities and have received proper authorization from the LMC. Trails and primitive roads will be posted with informational signs that clearly communicate restrictions regarding the operation of ORVs. The unauthorized use of ORVs traveling off designated roads, or in posted areas within the WLWA, will be regarded as criminal trespass. Violators are subject to criminal prosecution in accordance with applicable laws and regulations governing property protection.

\subsubsection{Visual Resource Management}

The DOE implements the BLM's Visual Contrast Rating System to determine the degree to which any proposed projects or other activities within the WLWA would affect the visual quality of the landscape. Using this system, any anticipated unacceptable visual impacts can be mitigated during the planning and design stage.

The DOE aspires to conduct all WIPP-related activities in accordance with visual resource objectives. Proposed activities and projects will be evaluated for consistency with existing laws and best management practices regarding scenic quality. The impacts of each 
action will be evaluated by the LMC and affected stakeholders, via ERs, EAs, and/or visual inspections of the proposed site prior to implementation. The ER will analyze the project significance, the visual sensitivity of the affected area, and the project impacts. Stipulations will be attached as appropriate to ensure compatibility of projects with management objectives for visual resources. Painting requirements will be implemented for surface facilities in accordance with existing guidelines (e.g., BLM painting requirements). Activities may be modified, at the discretion of the LMC, to blend with the native landscape.

Prior to commencement of work, contractors and/or subcontractors will be briefed on compliance guidelines for a "start-clean, stay-clean" philosophy. Inspections revealing unclean projects (e.g., excessive trash and debris in and around a work site), or projects that compromise the visual integrity of the surrounding area, will result in the immediate suspension of the project until such time as project cleanliness complies with the standards of this document.

Access to aesthetic visual resources of the WIPP (e.g., bird watching, wildlife photography, wildflower photography, etc.) will be encouraged and supported by cognizant WIPP professionals as time and funding constraints allow. Advocating access by nonconsumptive users reaffirms positive public perception and involvement with the WIPP.

\subsubsection{Hunting and Trapping}

Hunting inside the WLWA will continue in accordance with applicable traditional land uses, existing New Mexico Department of Game and Fish (NMDG\&F) and U.S. Fish and Wildlife Service (USF\&WS) regulations, and best management practices regarding the health and safety of WIPP personnel and the protection of the environment. Hunting within areas designated as "no trespassing" is prohibited. Violators are subject to prosecution under existing laws and regulations pursuant to property protection. The DOE after consultation with the BLM and the state of New Mexico, may impose regulations that prohibit or limit hunting or trapping if it is determined that the activity represents a profound safety risk to WIPP personnel and/or the public, creates significant adverse impacts to the environment, represents a potential threat to the integrity of threatened and endangered (T\&E) species habitat, and/or threatens the quality of life for isolated wildlife populations residing within the WLWA.

Trapping inside the WLWA will be allowed in accordance with applicable federal and state laws and regulations governing the taking of furbearers. Prerequisites that pertain to trapping on WIPP lands will be implemented in accordance with Subsection 3.2.5.2 of this plan.

\subsubsection{Horseback Riding and Hiking}

Recreational riding and hiking will be allowed in areas of the WIPP identified as "multiple land use areas." Restrictions such as "No Trespass" zones will apply as with nonDOE users. Except for posted areas, horseback riding and/or hiking by the general public will be encouraged to provide nonmotorized recreational experiences in addition to projecting affirmative relationships with nonconsumptive users. 


\subsubsection{Camping}

Note: Campers are required to check in with the WIPP security inspectors prior to establishing camp.

Camping will be allowed in areas designated as "multiple land use areas" within the WLWA. Names of campers, license numbers of vehicles, camp location, emergency phone numbers, and arrival and expected departure times shall be provided to the security inspectors. Campers must be informed that their camp is subject to random inspections at the discretion of security personnel. At the time of departure, campers will check out with WIPP security personnel. In the event that checkout does not occur, security personnel will deploy to the campsite for determination of camp status (e.g., abandoned, occupied, camper with injuries, vehicle problems, etc.).

Restrictions to inform the general public concerning camping in the WLWA will be posted on signs situated at access points to the area, in local newspapers, and in the state game hunting proclamation. 


\section{CHAPTER 7}

\section{ENERGY AND MINERAL RESOURCES}




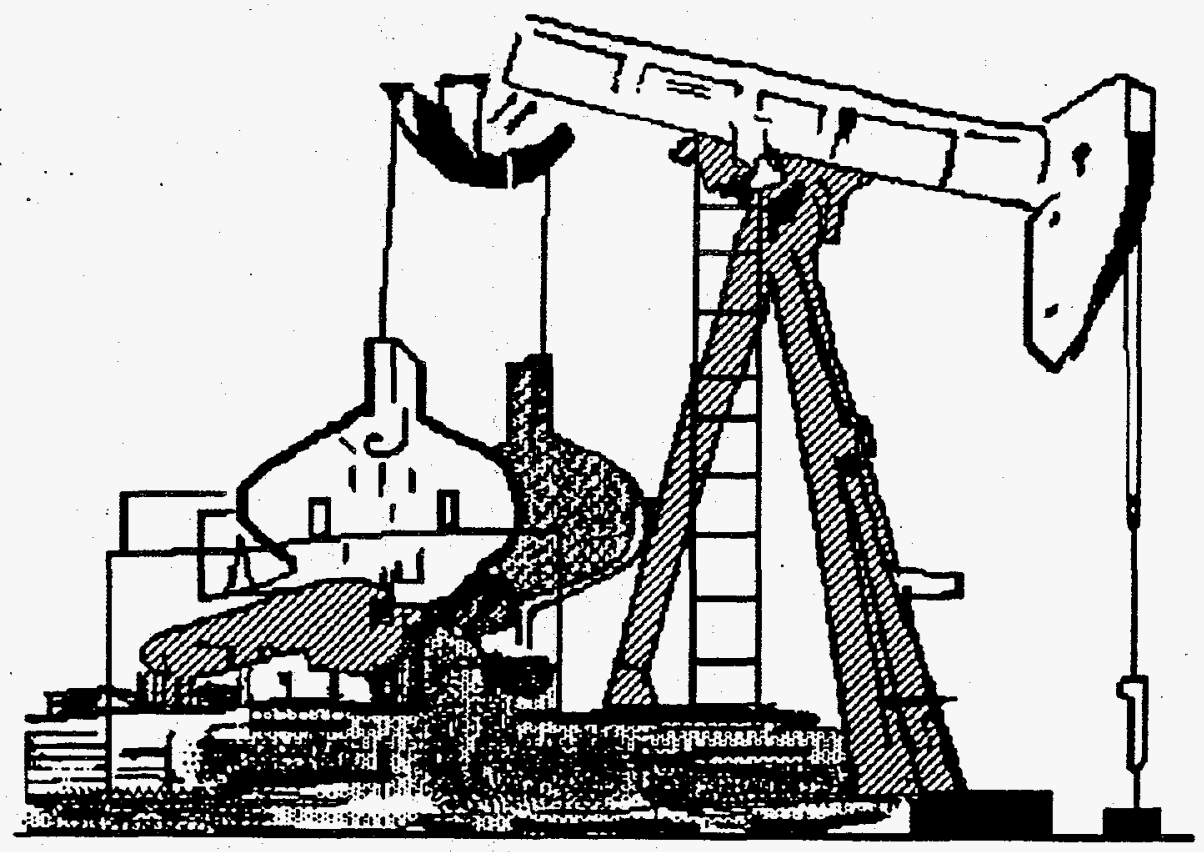




\section{CHAPTER 7 ENERGY AND MINERAL RESOURCES}

\subsection{INTRODUCTION}

This chapter discusses mineral resources and reserves as they pertain to the judicious management of lands under the jurisdiction of the DOE. This serves as a baseline management document for the determination and analysis of energy and mineral resources in the affected environment.

\subsubsection{Mineral Resources in the Affected Environment}

Mineable resources known to underlie the WLWA are caliche, gypsum, salt, sylvite, langbeinite, crude oil, natural gas, and distillate. Potassium salts (sylvite and langbeinite), which occur in strata above the repository, and hydrocarbons (e.g., crude oil and natural gas), which occur in strata below the repository, are the only resources of practical significance.

\subsubsection{Oil and Gas}

The oil and gas industry is well established in the Los Medaños region of New Mexico (the vicinity of the WIPP), with producing oil and gas fields, support services, and compressor stations. Nearly all phases of oil and gas activities have occurred in the locality. These phases include seismic exploration, exploratory drilling, field development (comprised of production and injection wells) and other sundry activities associated with hydrocarbon extraction. Oil and gas production was estimated, during 1992, at 60 million barrels of oil and 432 million MCF (thousand cubic feet) gas from the BLM's Carlsbad Resource Area with 12,656 wells identified in Eddy County. Combined with the production from the Roswell Resource Area, Southeast New Mexico accounts for 92 percent of the total oil production and 48 percent of the total gas production from the state of New Mexico. As identified in the Bureau of Land Management's Oil and Gas Potential Occurrence Zones, the Los Medaños region is located in a region designated as having a "high potential for oil and gas occurrence." This region, part of the Delaware Basin, is bordered by the Capitan Reef. The majority of hydrocarbon extraction has occurred outside the Basin, within the Reef. Although the Delaware Basin accounts for approximately 32 percent of lands in Eddy County, only 17 percent of oil and gas wells are located within its boundaries. During 1995, oil and gas reserves in the immediate vicinity of the WLWA were evaluated by the New Mexico Bureau of Mines and Mineral Resources (NMBMMR). Results from this evaluation were compiled in a report, Evaluation of Mineral Resources at the Waste Isolation Pilot Plant (WIPP) Site, March 31, 1995. 


\subsubsection{Potash}

Potash minerals are used to produce one of the major ingredients in fertilizers. There are twelve potash ore zones of Permian Age in the Carlsbad Mining District, all in the Salado formation. Detailed descriptions of these ore zones can be found in the Generalized Columnar Section and Radioactivity Log, Carlsbad Potash District by C.L. Jones, C.G. Bowles, and A.E. Disbrow (1954). The NMBMMR recently performed an evaluation of the potash resources in the vicinity of the WLWA (NMBMMR 1995).

There are five potash mining and refining operations in the area. These are: Eddy Potash; International Minerals and Chemical (IMC) Fertilizer; Western Ag Minerals; New Mexico Potash; and Mississippi Chemical Corporation. Horizon Potash discontinued operations in April of 1993. That same year, IMC and Mississippi Chemical expanded operations to increase production. According to Bureau of Land Management records, during 1992, these six potash companies produced 84 percent of the potash produced in the United States.

\subsubsection{Caliche}

Caliche, as the term is used in the Southwestern United States, refers to a buff, white, or reddish brown calcareous material of secondary accumulation, commonly found in layers on or near the surface of soils in the arid and semiarid regions. "Calcrete," "duricrust," and "hardpan" are other terms used to describe caliche in its various forms.

Caliche is considered a locally significant construction material due to its compaction properties. Deposits of caliche are frequently used for the construction of well pads, surfacing roads, and as a compacted base-course for buildings and paved roads. Although the caliche profile for the Los Medaños does not compare with the well developed Llano Estacado profile, several pits which produce a high-quality material are located in the vicinity. Access to this caliche, for use by the WIPP, is made available by way of Free Use Permits granted to the DOE by the BLM.

Several historic extraction pits are located within the WLWA. Historic pits within the WLWA are now the property of the DOE and will be managed as components for imminent restoration/reclamation in accordance with Chapter 9 of this plan.

Inasmuch as the LWA prohibits surface or subsurface mining unrelated to the WIPP, within the WLWA, supplementary conditions pertaining to caliche or potash extraction, within this document, are not relevant. Accordingly, text within this chapter will pertain to oil and gas exploration and production only.

\subsection{OBJECTIVES}

The objective of the DOE with respect to mining and oil and gas production is to ensure that the development of mineral leases does not affect the integrity of the disposal system. 


\subsection{PLANNED ACTIONS}

\subsubsection{Provisions}

In accordance with Section 4(b)(5) of the LWA, no surface or subsurface mining unrelated to the WIPP Project, or oil or gas production, including slant drilling from outside the boundaries of the WLWA, are permitted at any time (including after decommissioning) on lands on or under the WLWA, with two exceptions. These exceptions are two 320-acre (eight units) leases within the WLWA, below 6,000 feet, which are leased for oil and gas development (Federal Oil and Gas Leases NMNM 02953 and NMNM 02953C) (Figure 6.1). Both tracts, located in T.22 S., R. 31 E., Section 31, prohibit drilling within the first 6,000 feet of the surface. In accordance with the WIPP Land Withdrawal Act, existing rights under these leases will not be affected unless the Administrator of the Environmental Protection Agency (EPA) determines, after consultation with the Secretary of Energy, that the area in question should be purchased.

\subsubsection{Surveillance}

Surveillance of drilling and mining activity within one mile of the withdrawal boundary will be conducted by the DOE in coordination and cooperation with the BLM and/or the state of New Mexico in accordance with the MOU (Appendix C) and the concurrent statement of work (Appendix D). The BLM and state agencies have agreed to forward APDs and mining and reclamation plans to the DOE for review and comment in determining issuance of any drilling or mining permit within one mile of the WLWA. In addition to those commitments contained in the MOU and statement of work, the DOE shall conduct perimeter surveillance to verify proposed drill locations in accordance with Application for Permit to Drill (APD) submittals and evaluate potential encroachment of ancillary activities associated with producing wells and mines.

\subsubsection{Department of Energy Response to Mining Plans and Applications for Permit to Drill}

As directed by the existing MOU between the BLM and the DOE, WIPP personnel will receive APDs and mining reclamation plans from the BLM regarding activities proposed to be conducted within one mile of the WIPP site boundary. The DOE will field-verify the proposed locations and respond to the BLM, within 15 days, with DOE stipulations for approval. Companies that file for proposed drilling activities within 330 feet of the WIPP boundary may be required, at the recommendation of the DOE (and in accordance with existing DOE/BLM MOUs), to submit a daily set of drilling logs or "suite" of logs for verification, by the DOE, that the horizontal displacement of the well at no time encroaches on the WIPP site boundary. In the event of encroachment, a trespass condition will exist. The company will be required to cease drilling activities immediately, and plug and seal the region of trespass in accordance with all applicable laws and regulations that govern drilling activities, and to the satisfaction of the DOE, prior to proceeding with completion of the well. 
Transmittal of proposed resource extraction applications or mining plans to the DOE by the BLM and/or the appropriate state agencies are formalized through MOUs or similar agreements. 


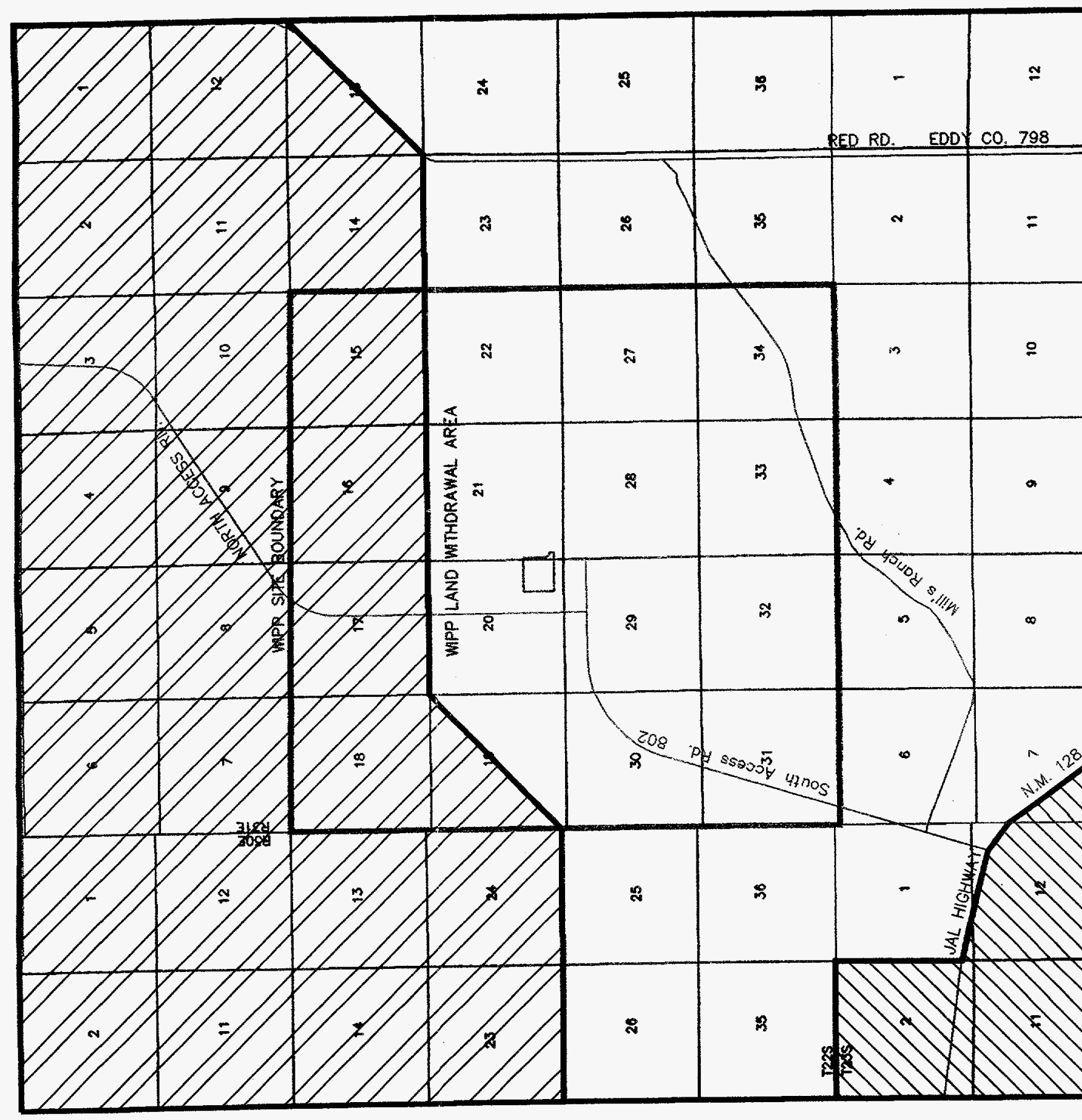




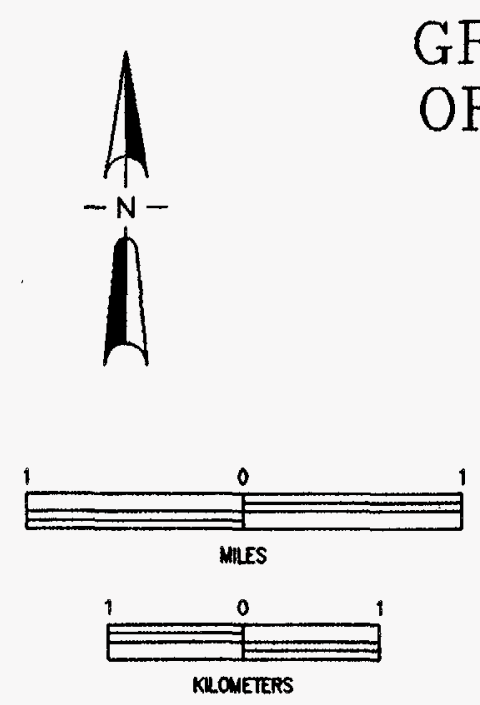

GRAZING ALLOTMENTS IN THE VICINITY OF THE WIPP LAND WITHDRAWAL AREA
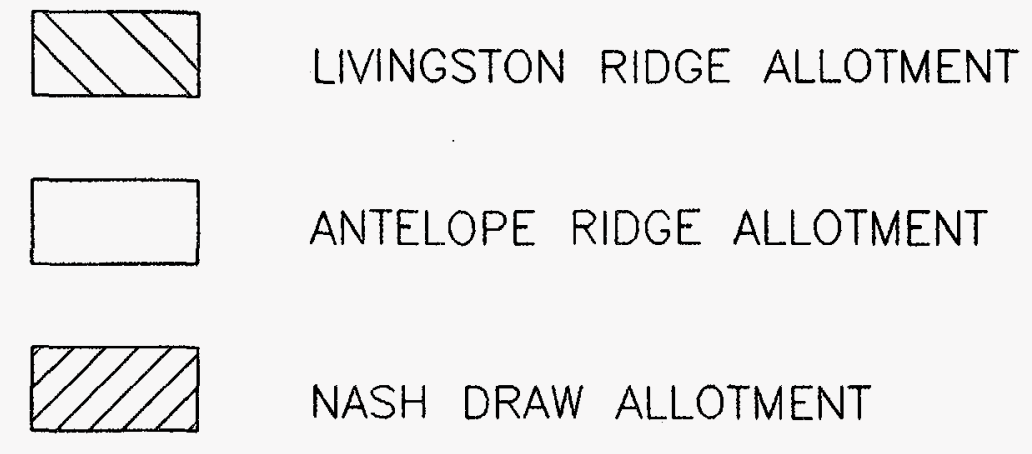

ANTELOPE RIDGE ALLOTMENT

NASH DRAW ALLOTMENT

FIGURE 5.1 
CHAPTER 8

\section{LANDS AND REALTY}




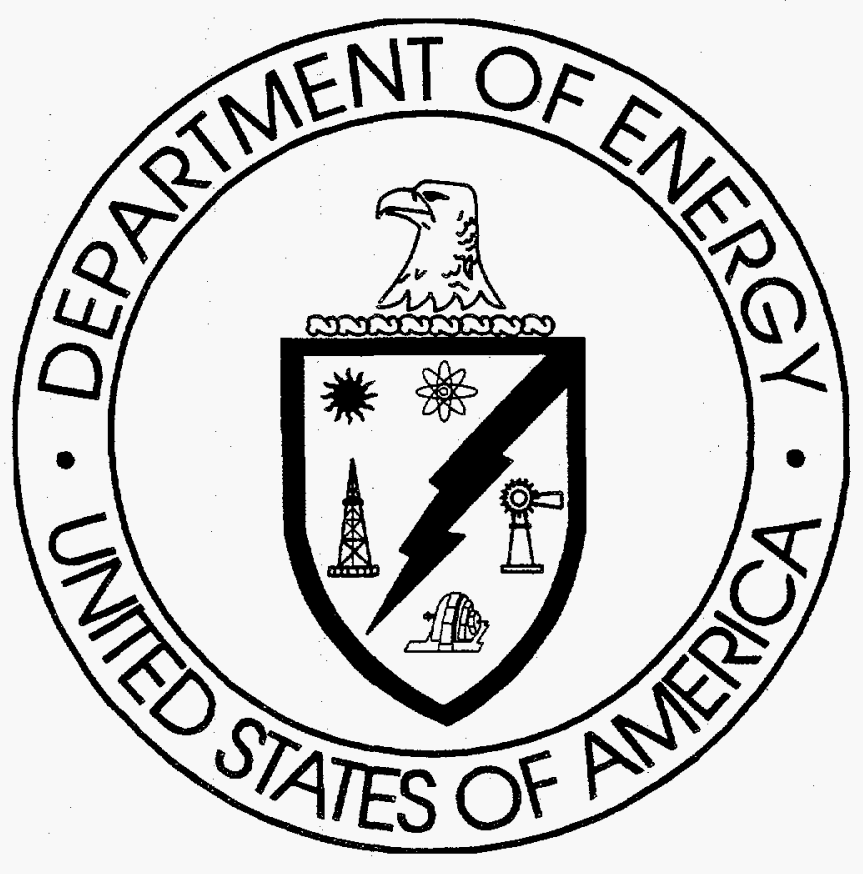

U.S. DEPARTMENT OF THE INTERIOR BUREAU OF LAND MANAGEMENT

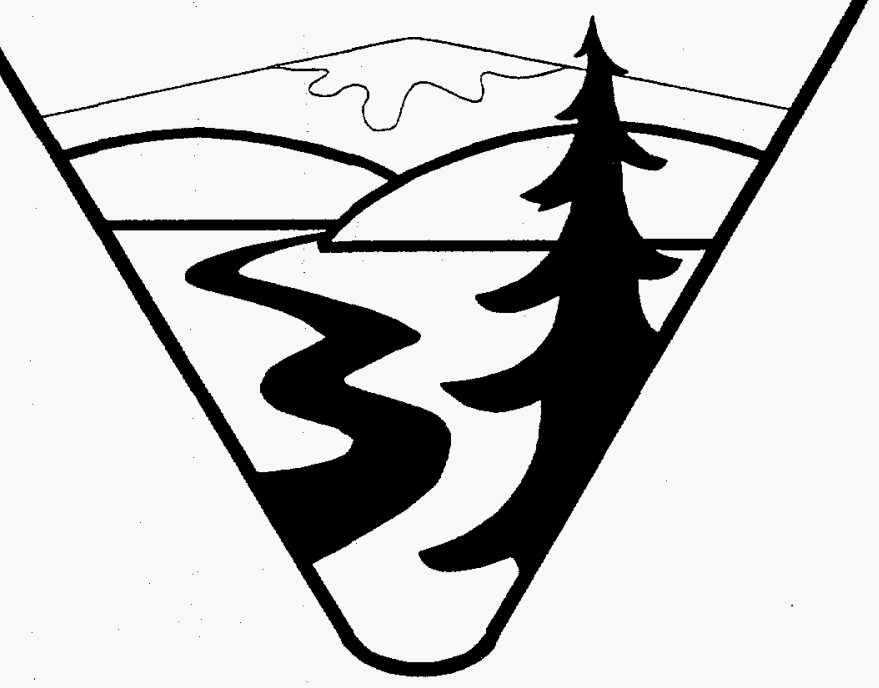




\section{CHAPTER 8 LANDS AND REALTY}

\subsection{INTRODUCTION}

This chapter identifies land use management responsibilities of the DOE as they pertain to general realty issues, access corridors, rights-of-way, and avoidance areas that affect, but are not solely contained within, the WLWA.

\subsubsection{Lands and Realty within the Affected Environment}

WIPP Lands are relatively well consolidated within the boundaries of the 10,240 acre WLWA. There are, however, additional properties outlying the WLWA boundary, used in the operation of the WIPP, that are managed under the custodial auspices of right-of-way reservations granted (typically) by the Bureau of Land Management or the state of New Mexico. Groundwater monitoring well pads, their access roads, and environmental monitoring sampling stations predominate this property category for lands under the jurisdiction of the WIPP.

Access to the WIPP site is from U.S. Highway $62 / 180,13$ miles to the north (North Access Road), and from Highway 128, four miles to the south (South Access Road). Rail access to the WIPP site is provided by a rail line connecting with a spur of the Atchison, Topeka, and Santa Fe railroad near the Western Ag-Minerals Nash Draw mine six miles southwest of the site (Figure 9.1).

WIPP lands may be designated, at the discretion of the LMC, as right-of-way corridors or as avoidance areas to protect environmental and social values while optimizing economic efficiency for utilities and transportation facilities. The LMC will identify which lands will be avoided when routing future rights-of-way in order to protect sensitive resource values, and which areas may be designated as corridors. Major rights-of-way used in the operation of the WIPP, in addition to those that existed prior to land withdrawal, were acquired from the BLM. Existing rights-of-way are commonly associated with linear facility development (e.g., power lines, gas lines, water lines).

Development and/or maintenance of adequate access routes within the WLWA represent significant concerns. 


\subsection{OBJECTIVES}

The objective of the DOE is to ensure proper management and maintenance of DOE/WIPP lands and realty (e.g., rights-of-way and access routes), in addition to providing safe and adequate access to the WIPP site while protecting the security of WIPP personnel, lands and realty (e.g., facilities). The DOE will consult with BLM and the State of New . Mexico, as appropriate, on future rights-of-way actions needed outside the WLWA.

\subsection{PLANNED ACTIONS}

\subsubsection{Proposals for New Access Routes, Easements, and Rights-of-Way}

The DOE will examine, by way of the LMC and in accordance with Chapter 2 of this document, proposals from land users (WIPP and non-WIPP) that impact lands/realty, under the jurisdiction of the DOE to include: new access routes; easements; and rights-of-way when such access will not cause significant adverse impacts to other resources. In addition, the DOE will:

1. Review and comment on applications or proposals received from the BLM for access routes, easements, and rights-of-way affecting, but not solely contained within, the WLWA.

2. Forward to the New Mexico Environment Department (NMED) Hazardous and Radioactive Materials Bureau/DOE Oversight Bureau, within 30 days of receipt from or submittal to the DOI BLM:

A. Applications or proposals for any access routes, easements, and rights-ofway affecting, but not solely contained within, the WLWA; and

B. Any DOE comments developed on such applications or proposals.

\subsubsection{Utility Development}

In general, WIPP lands are available for utility and transportation facility development; however, applicants will be encouraged to locate any new facilities within existing right-of-way corridors. Deviations from existing corridors may be permitted on the basis of the need of the proposal and lack of conflicts with other resource values and uses.

\subsubsection{Avoidance Areas}

Right-of-way avoidance areas are defined as areas where future rights-of-way may be granted only when no feasible alternative route or designated right-of-way corridor is available. Terms and conditions of right-of-way grants will depend on the sensitivity of the affected resources and existing laws and regulations established as protective measures for the area in question. 


\subsubsection{Access Permits}

The DOE will not grant permits for access when reasonable access already exists. Exceptions may be considered by the LMC only if the requestor presents, to the satisfaction of the LMC, a compelling need. [Note: See Chapter 2, "Environmental Compliance, " for permitting protocol.]

\subsubsection{Advertising}

No commercial advertising signs will be allowed on WIPP lands. Violations will result in prosecution of the violator commensurate with laws governing property protection. Directional and road signs must be authorized by the DOE and must conform with DOE specifications and configurations.

\subsubsection{Rights-of-Way, Rights-of-Way Corridors, and Realty Components}

Realty components constructed, maintained, and/or utilized in the operation of WIPP, under existing custodial right-of-way reservations include, but are not limited to, the following:

\subsubsection{North Access Road}

The North Access Road is a private road granted, for perpetuity, under right-of-way reservation NM 55676 on August 24, 1983. The North Access Road is approximately 13 miles in length with an easement width of 120 feet. This road is restricted for use by the personnel, agents, and contractors of the DOE on official business related to the WIPP Project, or to personnel, permittees, licensees, or lessees of the BLM. Signs are placed and will be maintained at the turnout of Highway $62 / 180$ stating the restrictions on access. Persons desiring access to Highway 128 should use the Lea County Line Road immediately to the east. Right-of-way NM 55676 was amended on April 22, 1988 to facilitate the construction of livestock fencing along either side of the subject road.

\subsubsection{South Access Road}

Eddy County Road 802 is designated as the South Access Road. This road originates at the turnout of Highway 128 and terminates as the pavement ends at the confluence of Sections 28 and 29 in T.22 South, R.31 East. This is a county road constructed in accordance with BLM Right-of-Way permit NM 46130. Terms for the right-of-way are for ". . . 50 years after the date of grant." The road configuration consists of a right-of-way width of 80 feet, two 12 foot driving lanes, two-to-four foot shoulders, and parallel "bar" ditches. Multiple-use access will be allowed unless it is determined that access by industry or the general public represents a significant safety risk to WIPP personnel. Upon determination, general access on Eddy County Road 802 may be restricted at the boundary of the 1454-acre Off-Limits Area in accordance with DOE Order 5632.6, Physical Protection of DOE Property and Unclassified Facilities. 


\subsubsection{Water Service Pipeline}

Water service for the WIPP facility is furnished by a water line that originates 31 miles north of the facility. Maintenance and operation of the water line is performed in accordance with the conditions of Contract DE-AC04-86AL24138-M002 between the City of Carlsbad and the DOE under right-of-way reservation NM 53809 issued to the U.S. Army Corps of Engineers acting on behalf of the DOE. The volume capacity of the water line is such that it meets all water requirements for the operation of the WIPP facility, as well as provides the City of Carlsbad with untreated water.

The initial 16-mile segment of the line is a 24 inch diameter line that accommodates the city of Carlsbad deliveries in excess of that required by the WIPP facility. The city of Carlsbad is authorized to use capacity in the initial 16-mile segment that is in excess of 500 gallons per minute, provided that:

- Any such use of the excess capacity by the city of Carlsbad will be without any cost or liability to the DOE.

- The city of Carlsbad will notify the DOE not less than 30 days in advance of the installation of each new tap and/or service capacity commitment which the city of Carlsbad intends to serve from the DOE's line.

- Upon request by the DOE Contracting Officer, the city of Carlsbad will provide a monthly tabulation of deliveries by tap point for the preceding 24 months.

In the final 15 -mile (10 inch diameter) segment, the DOE has authorized the $3 / 4$ inch water tap lines to supply water to livestock drinking tanks. Additional tap points may be added from time to time with advance approval of the DOE. Water delivered at such tap points will be metered and billed by the city of Carlsbad consistent with the city of Carlsbad's rates and procedures for providing service to its regular customers.

Future use of the water pipeline within the WLWA will be determined at the time of decommissioning of the WIPP facility.

As specified in Contract DE-AC04-86AL24138-M002, the city of Carlsbad will provide the DOE's water requirements free of consumption charge and maintain the water line, at its expense, during the initial term of the contract and any optional extension terms thereafter. Single maintenance projects involving repairs or replacements that cost in excess of $\$ 10,000$ will be considered abnormal and will be funded by the DOE, provided that such repairs or replacements are not the result of the fault or negligence of the city of Carlsbad or its customers, and provided further that the city of Carlsbad will first obtain the advance approval of the Contracting Officer (DOE) for any maintenance project requiring the DOE funding. This contract will be renegotiated between the DOE and the city of Carlsbad every five years. 
An operating committee, comprised of (no fewer than) two representatives from the DOE and other affected city, county, state, and federal agencies, will be formed. The responsibilities of the operating committee will be:

- To establish standard procedures and practices for the operation and maintenance of the water line.

- To review any technical studies that may be conducted during the term of the contract and keep the Contracting Officer (DOE) and the city of Carlsbad currently advised as to matters needing attention.

\subsubsection{Access Railroad}

Rail access to the WIPP site is provided by a rail line connecting with a spur of the Atchison, Topeka, and Santa Fe railroad near the Western-Ag Minerals Nash Draw Mine six miles southwest of the site (Figure 9.1). This section of rail was constructed under the auspices of right-of-way reservation NM 55699 granted on September 27, 1983, is approximately five miles in length and consists of an adjacent frontage road, in addition to the rail. Both railroad and service road were constructed on an easement width of 150 feet. The railroad and the concurrent easement road will be maintained, in accordance with Chapter 13 of this document, until such time as the determination is made that the rail spur is identified for decommissioning.

\subsubsection{Transmission Line}

The WIPP is serviced by an overhead electrical transmission line that traverses the WLWA for two miles to the north (right-of-way reservation NM 43203) and an additional two miles to the south (right-of-way reservation NM 91163). The southern terminal of the line is approximately five miles south of the WIPP at a location identified as the Southwest Public Service Company's Sand Dune Substation. Access to the power line easement is restricted to WIPP employees and SPS employees. Unauthorized access to the easement is prohibited and will result in DOE response commensurate with property protection (see Chapter 10, Security).

\subsubsection{High-Pressure Gas Line}

A twelve-inch, high-pressure, interstate gas line with a corresponding easement road traverses portions of Sections 15, 16, 17, 19, and 20 of the WLWA. Maintenance and operation of the line and the easement road are the proprietary responsibility of the El Paso Natural Gas Company (the owner/operator of the line) under right-of-way reservation LC 060762 . The WIPP periodically uses the easement road for access to the east and, therefore, will conduct maintenance activities (as needed and in accordance with WIPP maintenance protocol) (see Chapter 13 Maintenance and Work Control) to the road in order to provide adequate and safe access for WIPP vehicles (e.g., emergency response vehicles). 


\subsubsection{Sewage Lagoon}

The WIPP sewage lagoon system is a zero-discharge facility consisting of two primary settling lagoons, two polishing lagoons, a chlorination system, and three evaporation basins. The entire facility is lined with 30 mil synthetic liners. The facility is designed to dispose of domestic sewage and site-generated brine waters from observation well pumping and from underground dewatering activities at the site.

The WIPP sewage facility is operated under the New Mexico Discharge Plan (DP-831) and managed in accordance with the EPA sewage sludge regulations (40 CFR 503), the New Mexico Solid Waste Management Regulations (Part 700), the New Mexico Water Quality Control Regulations (3-100), and the WIPP Sewage Sampling Procedure, WP 02-EM1001. These requirements provide guidance for disposal of domestic sewage, site generated brine waters, and site generated non hazardous waste waters.

A determination is made on a case-by-case basis to determine regulatory requirements for onsite or offsite disposal of sewage sludge. Small quantities of sludges generated at the WIPP site have been used as fertilizer and soil stabilizers for WIPP reclamation projects. All sludges are analyzed in accordance with regulatory requirements of 40 CFR 503 before they are applied to the reclamation areas.

\subsubsection{Groundwater Surveillance Wells}

WIPP personnel monitor 65 well bores and their corresponding locations on or in the vicinity of the WIPP site (Figure 13.1). Well depth ranges from approximately $\mathbf{5 2 5}$ feet to 750 feet. These respective well bores are used to conduct surveillance of water elevation (groundwater level) data. In addition, 7 of the 65 wells contribute water characterization data to the Water Quality Sampling Program of the WIPP. These evaluations are used to determine the physical and chemical characteristics and maintain surveillance of groundwater elevation surrounding the WIPP facility, both before and throughout the operational lifetime. of the facility. Well locations located beyond the WIPP Site Boundary were constructed and are maintained under the guidelines of existing right-of-way reservations for each respective well. All well locations are periodically inspected, the existing well pads examined, and any nonconformities identified, reported, and dealt with accordingly.

In the event a well is considered inoperative (i.e., no longer needed for groundwater surveillance), the well will be plugged and sealed in compliance with State and Federal regulations in effect at the time. This procedure will apply as each DOE well (e.g., a well within the jurisdiction of the DOE or a well the DOE has assumed responsibility for) becomes abandoned until such time that all commensurate wells are plugged and sealed. Well pads and associated roads will be ripped, leveled, and reseeded in accordance with provisions contained in pertinent permits, agreements, and reclamation requirements identified in this document. 


\subsubsection{Salt Tailings Stockpiles}

Salt from the underground mining operations is brought to the surface and stored in a bermed salt pile just north of the surface facilities. The salt storage pile contains approximately 408,000 cubic yards of material, with a capacity to store the estimated $2,116,400$ cubic yards of material projected to be excavated during the lifetime of the WIPP project. There is also an inactive storage pile containing roughly 162,000 cubic yards within the DOE Exclusive Use Area, east of the Property Protection Area fence. This pile, referred to as the Site and Preliminary Design Validation (SPDV) pile, resulted from accumulation of material(s) extracted during the drilling of one 12-foot diameter and one 6 -foot diameter shaft to the repository depth of 2,150 feet and the initial excavations underground.

Salt from the north stockpile, which is not needed for decommissioning will be disposed of under sections 2 and 3 of the Act of July 31, 1947 (30 U.S.C. 602, 603; commonly referred to as the "Materials Act of 1947"). After disposal of the salt, the stockpile area will be reclaimed in accordance with stipulations for reclamation contained within this document (see Chapter 9 Reclamation/Environmental Restoration).

Disposition of the SPDV stockpile area will be determined after the pile is characterized for material content. As with the north stockpile, reclamation of the SPDV stockpile will be conducted in accordance with reclamation protocol(s) described in this document. 


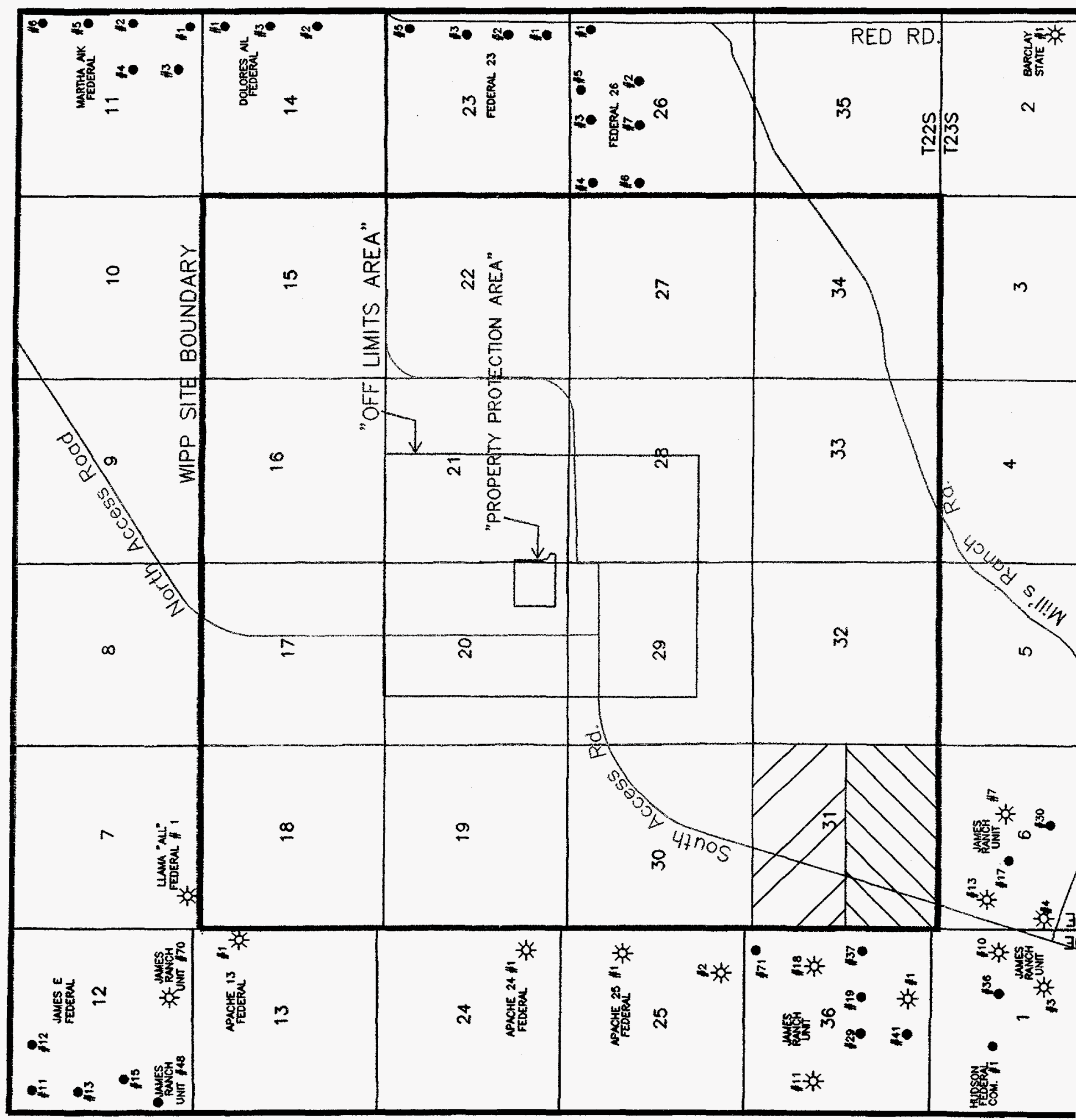




\section{OIL AND GAS WELLS WITHIN \\ ONE MILE OF THE WIPP LAND WITHDRAWAL AREA}
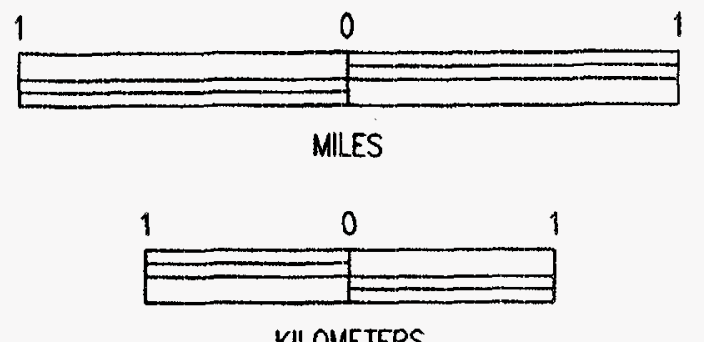

KILOMETERS

$\mathbb{A}_{-N}^{-N}$
- - oll well

深 - GAS WELL

Note: Production well icons denote well status according to firsthand field observations

FIGURE 7.1
FEDERAL LEASE NM-02953-C

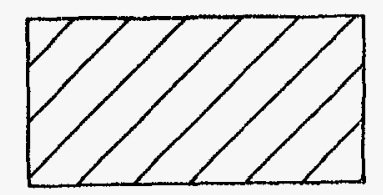

FEDERAL LEASE NM-02953

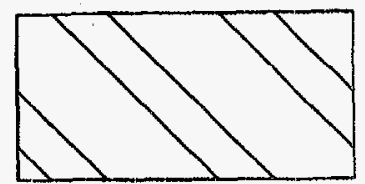




\section{CHAPTER 9}

\section{RECLAMATION/ENVIRONMENTAL RESTORATION}




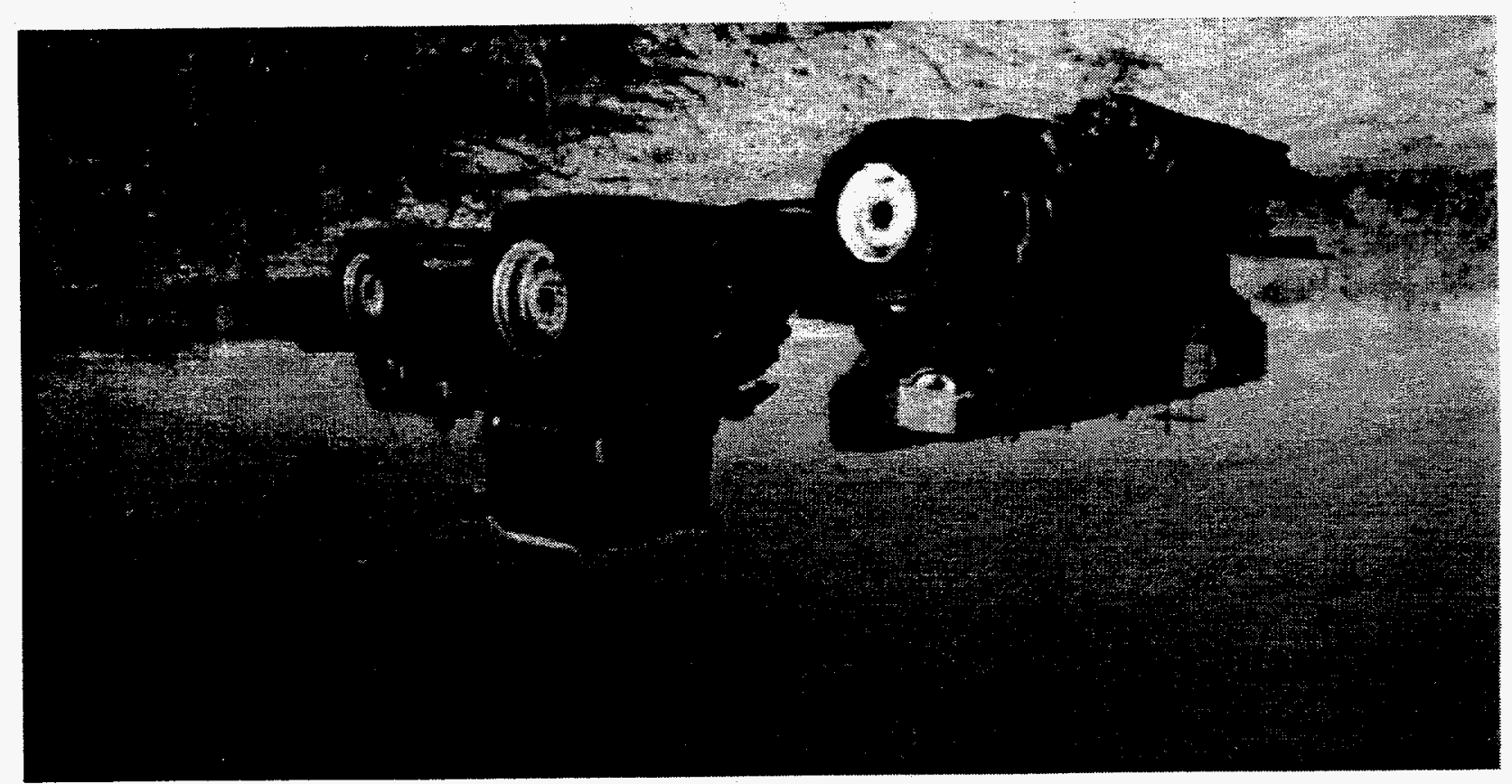




\section{CHAPTER 9 \\ RECLAMATION/ENVIRONMENTAL RESTORATION}

\subsection{INTRODUCTION}

This chapter identifies responsibilities of the DOE pursuant to applicable federal, state, and local environmental regulations to enhance and restore areas affected by the WIPP activities, to include areas disturbed prior to WIPP activities that were accepted as part of the land transfer from the BLM to the DOE. This chapter is designed to be revised as needed and is no way limited, except by law, to revisions based on new techniques for reclamation and new plans which the WIPP may incorporate in the future.

\subsubsection{Reclamation in the Affected Environment}

WIPP reclamation activities will be conducted in accordance with the Environmental Protection Implementation Plan (DOE/WIPP 90-050); DOE Order 5400.1, General Environmental Protection Program Requirements; the DOE Organization Act (42 U.S.C. 7112); the Federal Land Policy and Management Act of 1976 (Public Law 94579); the Final Supplement to the Environmental Impact Statement (SEIS) WIPP (DOE/EIS0026-FS, January 1990); the Final Environmental Impact Statement, (DOE/EIS-0026); and all applicable reclamation requirements by federal laws and regulations, Executive Orders, MOUs, DOE Orders, and state and local laws. These commitments include any unforeseeable future mandates or amendments to existing regulations.

In accordance with this document, the WIPP will implement a contemporary reclamation program and corresponding long-range reclamation plan. As locations are identified for reclamation, WIPP personnel will reclaim these areas by using the best acceptable reclamation practices. Seed mixes used will reflect those species indigenous to the vicinity and priority will be given to those plant species which are conducive to soil stabilization, wildlife, and livestock needs.

Without an active reclamation program, the establishment of stable ecological conditions in arid environments may require decades or centuries to achieve, depending on natural and unnatural disturbance and environmental conditions present during the entirety of the reclamation process. Reclamation activities will reduce soil erosion, increase the rate of plant colonization and succession, and provide habitat for wildlife in disturbed areas. In addition to maintaining the compliance posture of the WIPP with respective external entities, reclamation will ultimately serve to mitigate the effects of WIPP-related activities on affected plant and animal communities. 


\subsection{OBJECTIVES}

The objective of the DOE reclamation program is to return lands used in the operation of the WIPP that are no longer commissioned for WIPP operations to a stable ecological condition. Plant species and topography of the reclaimed area will be conducive to the surrounding ecosystem. It is the intent of the DOE to establish reclamation guidelines for land use requestors.

\subsection{PLANNED ACTIONS}

The DOE will be responsible for reclaiming lands disturbed by DOE-funded activities. Reclamation for actions by outside agencies or organizations, completed on DOE property, or crossing DOE property, is the responsibility of the outside agency or organization. All reclamation activities must be completed in accordance with the following pertinent guidelines as prescribed by the WIPP LMC:

\subsubsection{Timeliness of Reclamation Projects}

Reclamation activities will be conducted as soon as is reasonably possible after the determination is made that an area is to be decommissioned. Scheduling of reclamation activities is done with mutual concurrence of the LUC and affected parties as applicable.

\subsubsection{Review of Reclamation Activities}

DOE will seek review of proposed reclamation activities, in advance, by the BLM and appropriate state agencies to ensure compliance with applicable DOE reclamation commitments. All proposed WIPP reclamation activities will be reviewed and approved by the cognizant reclamation task leader (WIPP LUC) in consultation with cognizant DOE personnel and affected stakeholders (LMC).

\subsubsection{Fencing of Reclamation Sites}

Reclamation activities include the fencing of the project with prescribed standard BLM fence configurations (e.g., bottom-strand barbless wire 16 inches from the ground, middle-strand barbed wire 26 inches from the ground, and top-strand barbed wire 38 inches from the ground for a three-strand range fence) to deter unauthorized use or grazing by livestock. The fence will remain in place until the determination is made by the LUC that plant succession has progressed to a state of ecological stability suitable to sustain livestock access.

\subsubsection{Reclamation Protocol}

Reclamation activities will incorporate low-impact, shallow-tillage protocol as often as is reasonably possible. This reclamation technique is preferred to mitigate the loss of ground moisture critical to seed germination. 


\subsubsection{Prioritization of Reclamation Sites}

The LUC will identify and prioritize sites for reclamation (e.g., pads, roads, pits, etc.). Prioritization determinations are made in consultation with the LMC (including affected stakeholders). All projects and/or facilities authorized by previous commitments (e.g., MOUs, cooperative agreements) will be managed by the LUC to project finalization per DOE commitments.

\subsubsection{Seed Mixes}

All reclamation areas will be sown with seed mixtures that are approved by the Land Use Coordinator. These mixes will reflect plant species indigenous to the area.

\subsubsection{Reseeding of Sites}

Reclamation sites with plantings that do not germinate within a reasonable time frame, to be determined by the Land Use Coordinator, will be reseeded.

\subsubsection{Reclamation and Cultural Resources}

Reclamation activities will incorporate mitigation plans regarding any potential adverse impacts to cultural resources imposed directly by reclamation activities, or by ancillary activities associated with reclamation projects.

\subsubsection{Decommissioning of the Waste Isolation Pilot Plant}

Section 13 of the WIPP Land Withdrawal Act requires the DOE to prepare, in consultation with the Secretary of the Interior and the State of New Mexico, a decommissioning plan for the WIPP. This plan must be developed by October 30, 1997. Once decommissioning of the WIPP facility begins, surface structures are to be abandoned, decontaminated, and removed (including support facilities such as power lines). Underground facilities will be decommissioned in accordance with all applicable laws, rules, and regulations in effect at the time. Decommissioning and subsequent surface reclamation activities will be in accordance with existing applicable regulations and pertinent decommissioning plans (e.g., DOE/WIPP 2065, Revision 0, Safety Analysis Report, Chapter 10, "Decontamination and Decommissioning"). 
CHAPTER 10

SECURITY 


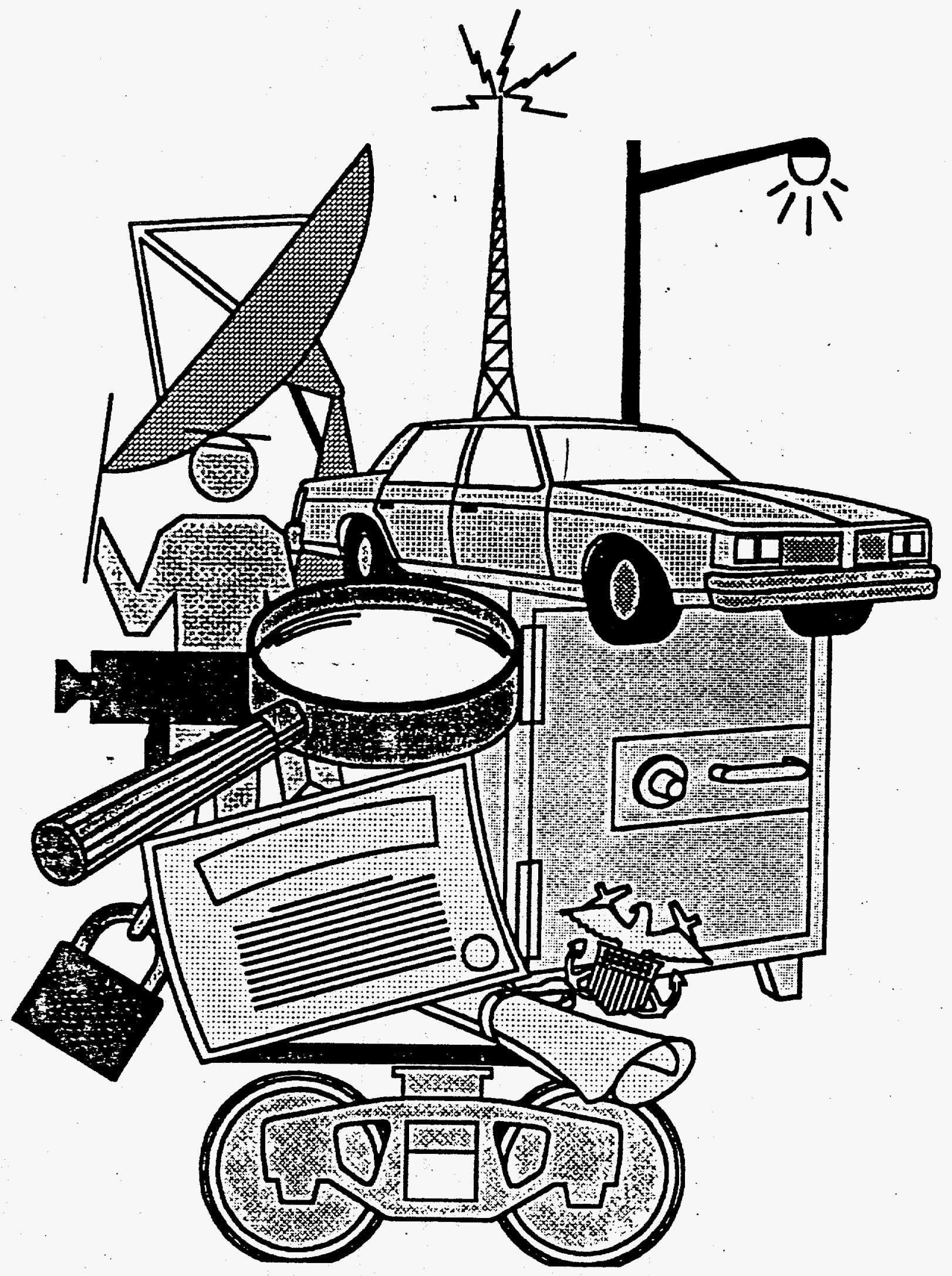




\section{CHAPTER 10 SECURITY}

\subsection{INTRODUCTION}

The security force for the WIPP consists of a staff of security officers, and support personnel on duty 24 hours a day. The WIPP security force maintains field vehicles, which are used several times daily for perimeter inspections.

\subsection{OBJECTIVES}

Security will be maintained in the classic sense within the Property Protection, Exclusive Use, and Off-Limits areas only. These areas are posted against trespass under the authority of Section 229 of the Atomic Energy Act of 1954, 42 U.S.C. 2278a, and pursuant to the regulations set forth in 10 CFR 860 and DOE Order 5632.6, Physical Protection of DOE Property and Unclassified Facilities. Security personnel will evaluate requests for services within the WLWA and make determinations based on DOE direction, manpower, and funding.

The objective of the security force will be limited to observation and reporting. Incidents requiring response or investigation will be referred to the proper legal authorities.

\subsection{PLANNED ACTIONS}

\subsubsection{Property Protection Area}

The interior core area of the facility (Figure 10.1) is a land area of approximately 34.16 surface acres surrounded by a chain link fence. This area, formerly identified as "Zone I," is designated as the "Property Protection Area." All access control features are maintained with uniformed security personnel on duty 24 hours a day.

\subsubsection{Exclusive Use Area}

The Exclusive Use Area (Figure 10.1) is comprised of approximately 277.14 acres within Sections 20, 21, 28, and 29 of Township 22 South, Range 31 East. It is surrounded by a five-strand barbed wire fence and is restricted exclusively for the use of the DOE, its contractors and subcontractors in support of the project. In addition, this area is defined as the point of closest public access for the purposes of performing accident consequences to the general public in the WIPP Safety Analysis Report (SAR). This area is marked by DOE 
"No Trespassing" signs and will be patrolled by WIPP security personnel to prevent unauthorized activities or uses.

\subsubsection{Off Limits Area}

The Off Limits Area (Figure 10.1) is a sector comprised of 1453.9 acres, or 2.2 square miles (more or less), within Sections 20, 21, 28, and 29 of Township 22 South, Range 31 East. This sector is managed as an area wherein unauthorized entry and the unauthorized introduction of weapons and/or dangerous materials. (as provided in $10 \mathrm{CFR}$ 860.3 and 860.4 ) is prohibited. Pertinent prohibitions and subsequent penalties (10 CFR 860.5) are posted at consistent intervals along the perimeter as directed in 10 CFR 860.6. Grazing and public thoroughfare continue until such time that these activities present a threat to the security, safety, and/or environmental quality of the WIPP. This sector will be patrolled by WIPP security personnel to prevent unauthorized activity or use. While the subject sector is posted, the area is not fenced.

\subsubsection{Waste Isolation Pilot Plant Land Withdrawal Area}

The WIPP Site Boundary distinguishes the perimeter of the 16 section (or 10,240 acres) WIPP Land Withdrawal Area (WLWA). This tract includes properties outlying the Property Protection Area, the Exclusive Use Area, and the Off Limits Area. This sector is designated at points of ingress and egress, as a Multiple Land Use Area, and is managed accordingly. Certain restrictions however do apply. Information regarding land use restrictions is available on request.

\subsubsection{Special Management Areas}

There are sectors used in the operation of the WIPP (e.g., reclamation sites, well pads, roads, etc.) that are identified as Special Management Areas (SMA). A SMA designation is due to values, resources, and/or circumstances that meet criteria for protection and management under special management designations. Unique resources of value that are in danger of being lost or damaged, sectors wherein ongoing construction is occurring, fragile plant and/or animal communities, sites of archaeological significance, sectors containing imminent risks (safety hazards), or a sector(s) that may receive an unanticipated elevated security status would be suitable for designation as a SMA. Accordingly, the subject sector would receive special management emphasis under this stipulation. SMAs will be posted against trespass and shall be safeguarded commensurate with applicable laws governing property protection. WIPP security personnel will patrol these areas to prevent unauthorized access or use. 


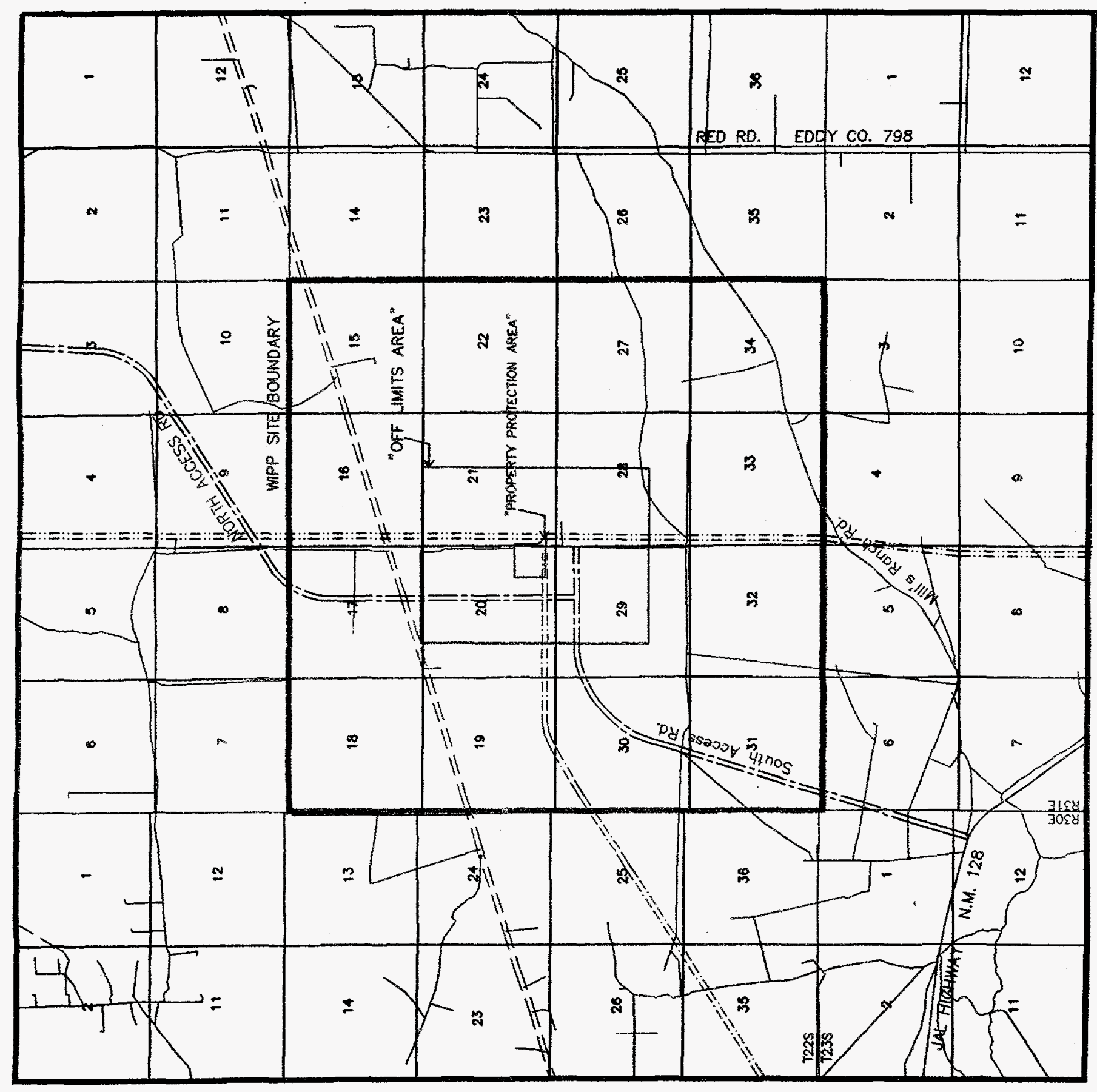


NORTH AND SOUTH ACCESS ROADS

12" INTERSTATE GAS LINE

$69 \mathrm{KV}$ OVERHEAD ELECTRICAL TRANSMISSION LINE

RAILROAD

NOTE: WATER ANO TELEPHONE LINE RIGHTS-OF-WAY ARE WITHIN THE NORTH ACCESS ROAD RIGHT-OF-WAY

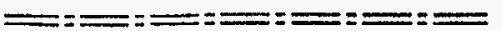

$== \pm=== \pm==$

=::=::=::=::=:=::=::=::=::=::=::=::=

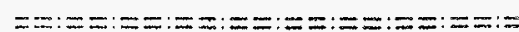

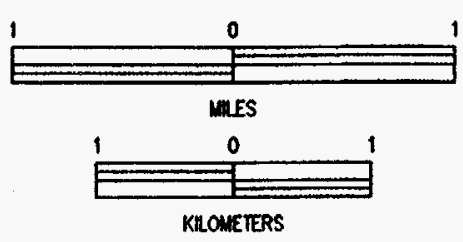

FIGURE 8.1 
CHAPTER 11

\section{EMERGENCY MANAGEMENT}



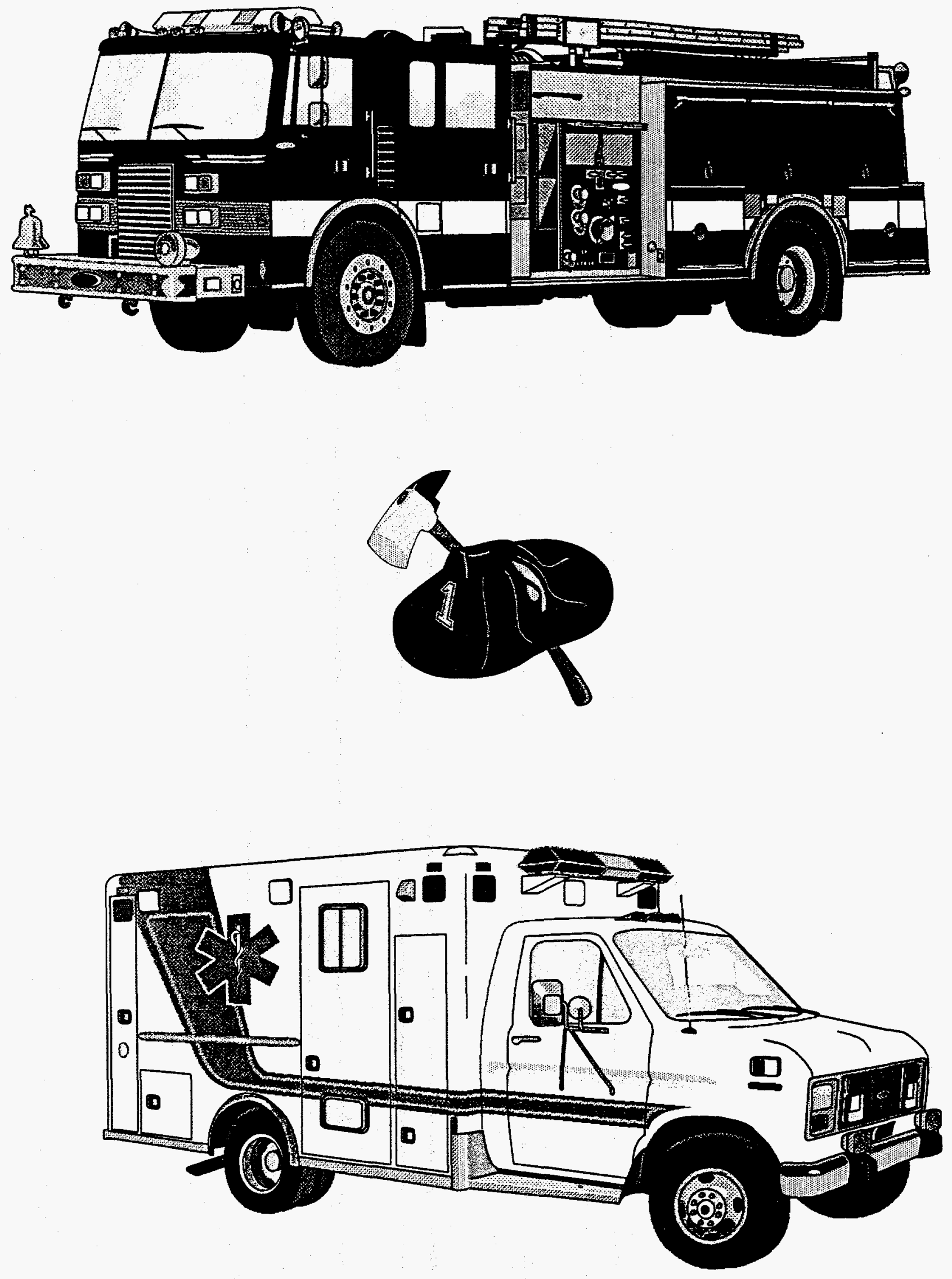


\section{CHAPTER 11 \\ EMERGENCY MANAGEMENT}

\subsection{INTRODUCTION}

In the event of an emergency contact the Central Monitoring Room at 234-8125, 234-8457 or 234-8111.

Preparations have been made to minimize the impacts of an emergency at the WIPP by preparing emergency plans and training for emergency responders.

WP 12-9, WTPP Emergency Plan and Procedures, was developed to provide a framework of the responsibilities, capabilities, and authorities for the members of the emergency response organization (ERO). The ERO members, for the purpose of this document, consist of the following personnel/teams:

- Emergency Services Technicians (ESTs)

- Emergency Response Team (ERT)

- Backshift Fire Brigade (BFB)

- Central Monitoring Room Operator (CMRO) (234-8125)

- Facility Shift Manager (FSM)

- RCRA Emergency Coordinators

\subsubsection{Emergency Services in the Affected Environment}

The WIPP maintains 24-hour readiness in the event of an emergency. Emergency response includes fire fighting capabilities and emergency medical technicians deployed in accordance with existing Mutual Aid Agreements (e.g.; with Carlsbad, Hobbs, and Eddy County, New Mexico). Emergency conditions of particular concern to the WIPP are both natural and anthropogenic (man-made). Natural disasters include wind, range fires, lightening, localized flooding, earthquakes, and tornadoes. Anthropogenic emergency conditions include fires, explosions, loss of power, hazardous atmospheres, external distuptions, mine accidents, hazardous emissions, heat stress, and equipment failure.

Plans have been implemented to minimize facility or programmatic impacts during an emergency condition at the WIPP Site. These plans apply to safety and security emergency preparedness and response actions to the following:

- Radiological Emergencies

- Underground Emergencies 
- Industrial Emergencies

- Security Emergencies

- National Emergencies

- Continuity of Government Emergencies

- Natural Disaster Emergencies

\subsubsection{Responsibilities}

\subsubsection{Emergency Services Technicians/Incident Commander}

The EST is responsible for the overall incident command of an emergency until the emergency is mitigated. The EST is in charge of life and/or property threats that lie within the WLWA boundary (i.e., medical, rescue, fire, hazardous materials). The EST may also be activated outside the WLWA boundary by the Facility Shift Manager (FSM) in accordance with existing MOUs. MOUs shall be accommodated at the discretion of the FSM, in accordance with existing facility operations standing instructions, unless an on site emergency takes priority over actions prescribed in the MOU.

\subsubsection{Emergency Response Team}

The ERT is trained to incident-specific response, including, but not limited to, medical/ rescue, fire fighting, release of hazardous materials/waste, and contaminated/injured personnel. The response to any one event by the team shall be in accordance with the applicable federal, state, or local standards and/or guidelines established for that response. The ERT responds to emergencies at the WIPP in accordance with prescribed procedures and training.

\subsubsection{Backshift Fire Brigade}

The BFB is comprised of security personnel. They provide fire, rescue, and medical response support to the EST from 4:00 p.m. until 7:30 a.m., Monday through Friday, and 24 hours a day on Saturday, Sunday, and holidays.

The BFB is trained to respond to fires (on site and off) in accordance with existing MOUs and/or mutual assistance agreements. Personnel of the BFB are trained in accordance with New Mexico Firefighter Level 1 training standards.

\subsubsection{Central Monitoring Room Operator (CMRO)}

The on-shift operator is responsible for Central Monitoring Room (CMR) operations and can be contacted by dialing $234-8125$ or $234-8457$. The CMRO, who reports directly to the FSM, has the authority and responsibility to activate response personnel and organizations when notified of incidents that require immediate response (e.g., personnel injury, spills, fires, etc.) as directed by existing emergency procedures. 


\subsubsection{Facility Shift Manager (FSM)}

This position is staffed 24 hours a day. The FSM is designated as the supervisor responsible for the overall day-to-day operation of the WIPP, including compliance with applicable Technical Safety Requirements and Safety Analysis Report. The FSM is the senior shift representative for WID management. The FSM is in charge of directing plant activities at the WIPP during emergencies until relieved by the Crisis Manager.

\subsubsection{Resource Conservation and Recovery Act Emergency Coordinator}

The RCRA Emergency Coordinator at the WIPP is the Facility Shift Manager during an activation of the RCRA Contingency Plan. Depending on the potential for adverse impacts, the FSM may transfer emergency response responsibilities to the Crisis Manager (e.g. in the event of an EOC activation the role of RCRA Emergency Coordinator is delegated to the Crisis Manager). There shall be a RCRA Emergency Coordinator onsite at the WIPP facility 24 hours a day, seven days a week, with responsibility for coordinating all emergency response measures. Those who are qualified to serve as RCRA Emergency Coordinators are thoroughly familiar with the WIPP Contingency Plan (WP 02-12); TRU mixed waste and hazardous waste operations and activities at the WIPP facility; locations of TRU mixed waste and hazardous waste activities; locations on the site where hazardous materials are stored and used; and locations of waste staging and accumulation areas. Persons qualified to act as the RCRA Emergency Coordinator have the authority to commit the necessary resources to implement the WIPP Contingency Plan.

\subsubsection{Emergency Operations Center}

The EOC is activated by the FSM when emergency conditions arise that cannot be mitigated without additional resources. The EOC is minimally comprised of a Crisis Manager, a Deputy Crisis Manager, an Operations representative, a Safety representative, and the EOC manager.

\subsection{OBJECTIVES}

The DOE's facility emergency preparedness objective is designed toward protecting and providing a safe environment for WIPP employees, contractor personnel, visitors, and the members of the general public during emergency situations. These include, but are not limited to wildland fires, radioactive and hazardous material (HAZMAT) accidents, tornadoes, floods, lightening strikes, and earthquakes. 


\subsection{PLANNED ACTIONS}

\subsubsection{Fire}

The DOE's fire management program is designed to ensure a timely, wellcoordinated, and effective response to suppress any wildfires within the WLWA. Once the CMR has been notified of a fire requiring response by emergency personnel, the CMRO will activate the EST, the ERT, and/or the BFB to mitigate the event. This includes activation to the WLWA boundary specified in the LMP.

The ERT/BFB will assemble at the Emergency Services Vehicle Bay to don personal protective equipment (PPE). The on-shift EST shall act as Incident Commander and direct all aspects of the fire response. The EST reports directly to the Facility Shift Manager. Moreover, activation may proceed outside this area as directed by existing MOUs.

\subsubsection{Strategy}

1. The DOE employs full suppression strategy for a wildfire within the WLWA by empowering the WIPP Incident Commander to coordinate fire management activities. The Incident Commander ensures that fire fighting activities adhere to the WIPP Pre-Fire Plans. The WIPP Pre-Fire Plans, kept in the WIPP fire truck and rescue vehicle, identifies entrances, exits, and any potential hazardous materials for each WIPP facility building.

2. Upon detection of a wildfire, within the WLWA, the BLM's Carlsbad Fire Control Officer is notified immediately. Upon arrival at the fire, WIPP personnel assess the situation and determine if additional support will be required. Should support be required, fire fighters from the BLM as well as Carlsbad, Hobbs, and Eddy County, New Mexico may be asked to assist in accordance with established Mutual Assistance Agreements.

\subsubsection{Resources}

The DOE will make a good-faith effort to acquire and maintain, in a state of readiness, the necessary resources to execute full suppression of a wildfire within the WLWA. The WIPP fire truck is intended primarily for protection of the WIPP facilities. This equipment must remain available for its primary objective. If conditions are such that WIPP personnel choose not to commit their forces to wild fires, WIPP Emergency Management personnel shall notify the BLM; and the BLM will coordinate suppression efforts.

\subsubsection{Reporting}

The DOE will provide notice, within 90 days, to the New Mexico Environment, Minerals, and Natural Resources Department (EMNRD) 
Forestry and Resources Conservation Division regarding the status of any wildfire or prescribed burn within the WLWA.

\subsubsection{Radioactive and Hazardous Materials}

The initial response to any radioactive and/or HAZMAT incident is directed to protect human health, safety, and the environment. All such incident responses shall be conducted by personnel wearing the appropriate level of PPE as required by 29 CFR 1910.120 (P).

The ERT provides initial response to spills that cannot be managed by the responsible individual(s). Upon request of the on-duty EST, after a spill has been stabilized, any contamination will be removed by cognizant personnel. If necessary, the WIPP will use other resources (e.g., local fire departments, state police, subcontractors) to mitigate spills.

\subsubsection{Strategy}

The EST has the following duties during a spill of hazardous or radioactive materials.

1. Provide initial incident command of any emergency actions pertaining to releases or spills, radioactive or hazardous materials, or unknown substances.

2. Provide, if no emergency exists, medical surveillance and additional technical support for operations requiring a site-generated hazardous waste worker.

3. Advise the FSM on conditions and progress.

4. Direct all operations involving releases that have the potential to harm responders involved in cleanup activities.

\subsubsection{Reporting}

Complete proper HAZMAT forms as directed by WP 12-ER 4902, Hazardous Materials Spill Response. Spills or releases of hazardous materials will be reported to regulatory authorities in accordance with applicable regulations. 



\section{CHAPTER 12}

\section{INDUSTRIAL SAFETY}




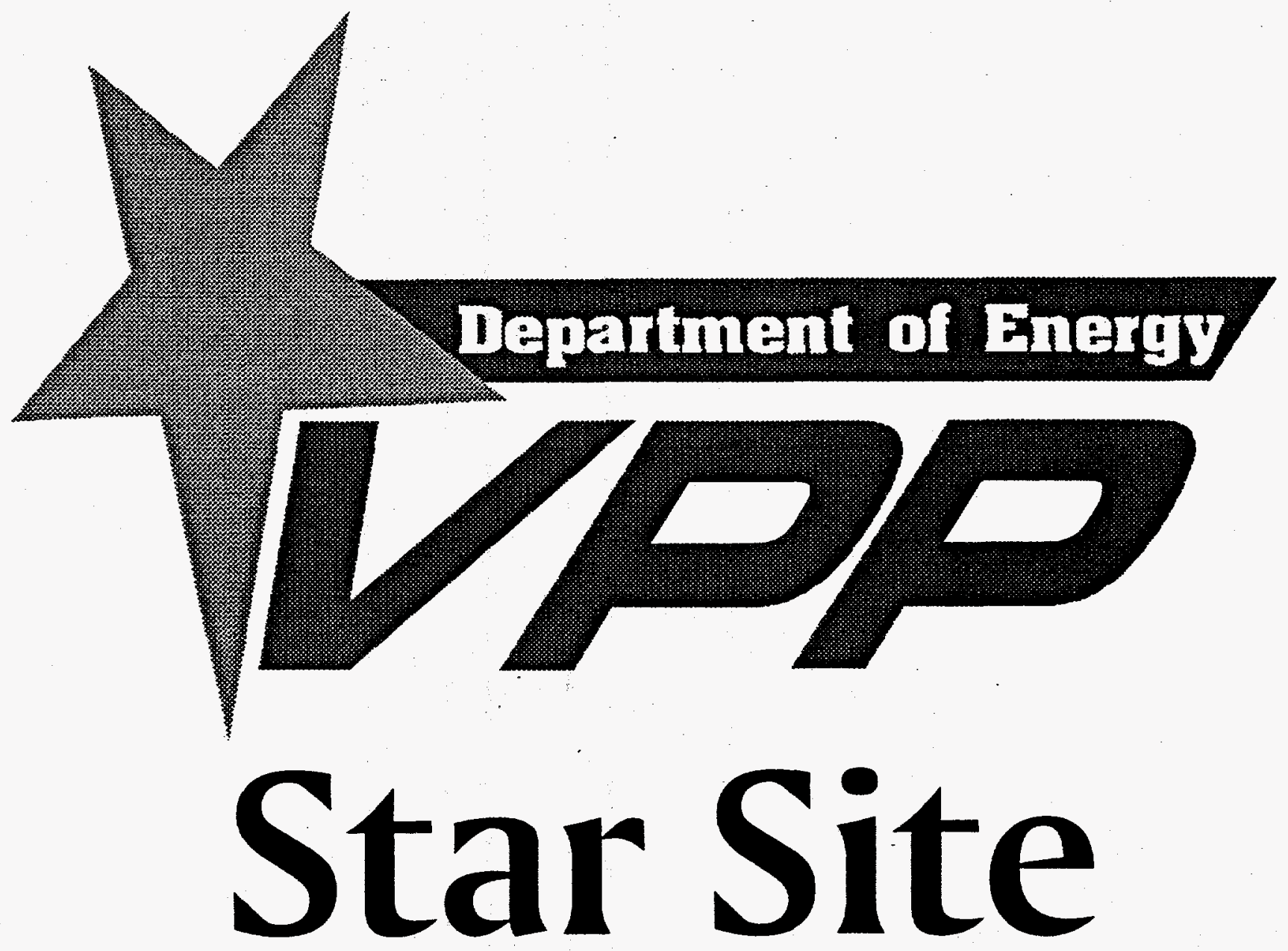




\section{CHAPTER 12}

\section{INDUSTRIAL SAFETY}

\subsection{INTRODUCTION}

\section{In the event of an emergency, contact the WIPP Central Monitoring Room at 234-8457, 234-8125, or 234-8111.}

The industrial safety requirements for this section cover work performed by subcontractors, work performed on approved easements, work performed by WIPP employees, and recreational activities conducted within the boundaries of the WLWA. This program supplements WIPP policies contained in spill control plans and emergency response plans that relate to safe practices. The types of activities covered by this program include, but are not limited to:

- Construction work, including buildings, annexes, warehouses, storage areas, etc.

- Repairs or alterations

- Equipment installation and servicing

- Routine contract maintenance

- Remediation work

- Scrap and waste removal

- Transportation (i.e., trucking and deliveries)

- Electrical, piping, rigging, roofing, etc.

- Environmental monitoring/land management work

\subsection{OBJECTIVES}

The objective of the DOE is to provide and maintain a safe environment for any who wish to use WIPP lands. Additionally, the industrial safety program will define, for all WIPP subcontractors and members of the general public who wish to use WIPP lands, the safety and health policies, rules, and guidelines for minimizing unsafe conditions and acts that may result in personal injury and/or property damage. This program will provide a mechanism for subcontractors to communicate their safety and health concerns to W.IPP safety and health personnel.

\subsection{PLANNED ACTIONS}

In order to maintain optimum conditions for a safe environment, the following are prohibited within the WLWA boundary: 
- Possession or use of alcoholic beverages

- Possession or use of a controlled substance (e.g., marijuana)

- Discarding refuse/trash within the WLWA

\subsubsection{Work Performed by Waste Isolation Pilot Plant Employees}

All work performed by WIPP employees should comply with the requirements of the WIPP Safety Manual, WP 12-1 (available on request), and other applicable site requirements.

Any activity (e.g., recreational hunting, camping, etc.) that is identified by the DOE as an imminent risk to the health and/or safety of WIPP personnel can, at the discretion of the DOE, be suspended indefinitely on the WLWA. Permanent prohibition of activities resulting in the contradiction and/or subsequent amending of this LMP shall be considered only after a review by the LMC in consultation with affected stakeholders.

\subsubsection{Safety Requirements for Subcontractors}

When WIPP personnel perform work on the WIPP site or at offsite WIPP locations (e.g., groundwater surveillance well pads), their activities and equipment could affect subcontractor personnel and WIPP employees and property. Consequently, it is necessary that certain safety requirements be followed at all times when such operations are performed.

Work performed within the WLWA, regardless of the point of origin of a purchase requisition (e.g., WID or Sandia National Labs), must comply with existing WIPP site safety requirements. Documentation for work performed on approved easements must be submitted to cognizant WIPP personnel for validation concerning the appropriate Occupational Safety and Health Administration (OSHA) requirements for the type of work to be performed.

Subcontractors who conduct drilling activities (e.g., groundwater monitoring wells) within the WLWA will be held accountable for compliance with American Petroleum Institute (API) Recommended Practices for Occupational Safety for Well Drilling and Servicing Operations, API Recommended Practices 54 (RP54).

\subsubsection{Policy}

Subcontractors ( to include lower-tier subcontractors) must comply with applicable local, state, and federal safety, health, and environmental regulations. The WIPP site representative (e.g., facility, work control, project engineer, or maintenance person in charge) will provide the site safety rules for which the contractor will be held accountable, and shall verify the adherence to these rules by the subcontractor. Site safety rules range from providing proper eye protection to compliance with the lockout/tagaut procedures (i.e., project-specific). The WIPP recognizes that the subcontractor may also require its employees to follow specific safety rules which exceed the WIPP rules. These will be acceptable, provided they do not conflict with WIPP site rules. 


\subsubsection{General Guidelines}

Since unsafe practices by subcontractors could expose WIPP employees to injuries and illnesses, a person cognizant of work packages and purchase requisitions will designate a subcontract technical representative (STR). The STR will monitor the practices of the contractor and establish a mechanism to control subcontractor services to assure that such services are performed in a safe manner.

\subsubsection{Prior to Commencement of Work}

Prior to commencement of work, all subcontractors are required to attend an on site preconstruction and safety conference. Conferences for construction (Davis-Bacon) subcontractors shall be conducted by WID Procurement Services; those for maintenance contractors (non-Davis-Bacon) shall be conducted by the WIPP STR.

\subsubsection{Submittals Required by Subcontractors}

\subsubsection{Construction Subcontractors (Davis-Bacon Work)}

The Davis-Bacon Act (40 U.S.C. $276 \mathrm{a}-276 \mathrm{a}-7$ ) is a federal law applicable to federally funded construction work in excess of $\$ 2,000$, which ensures that workers engaged in such construction work are not paid less than the scale of wages prevailing in the area in which the work is to be performed, as determined by the Department of Labor. Requisitions specify that each subcontractor shall provide WID Procurement Services the following information when bidding a project. This documentation will be reviewed and approved by the WID Industrial Safety Section.

1. Documentation of previous three-year injury experience and a current OSHA 200 Log.

2. Historical information (last three years) on any OSHA citations and other regulatory inspection reports or citations relative to the type of work to be performed.

3. Confirmation of workers' compensation coverage or equivalent, including the experience modification rate and other specific insurance coverage.

4. Copies of written safety policy and programs, which would include (as appropriate) but are not limited to (training requirements and supporting documentation):

- Hazard communication

- Respirator protection

- Respirator fit testing and medical approval

- Driving powered-industrial trucks

- Control of hazardous energy systems (lockout/tagout)

- Confined space entry 
- PPE use

(WIPP personnel will have control of lockout/tagout procedures within the core or fenced area and confined space entry procedures within the WLWA.)

5. Copies of the Material Safety Data Sheet (MSDS) for each chemical to be brought inside the WLWA. The MSDS(s) will be reviewed, evaluated, and approved by the WID industrial hygienist or designee before any chemical is permitted on WIPP lands. The contractor is responsible for removal and for cleaning up spills generated by their actions, including costs associated with the cleanup.

6. Written certification that all material handling equipment (e.g., cranes, hoists, powered industrial trucks, chains, slings, spreaders) have been inspected and meet all requirements of Subpart N of both 29 CFR 1910 and 29 CFR 1926.

7. Written job hazard analysis for each phase of the work to be performed.

When specified in the subcontract, contractors are required to supply work plans describing the type of work to be performed, the number of people performing task(s), their emergency action plan, their safety rules, and the names of responsible personnel.

Subcontractor personnel are required to complete the appropriate WIPP training requirements prior to operating any WIPP site equipment, performing unescorted lockout/tagout functions within the fenced area, or entering any area within WIPP lands labeled as a confined space or meeting confined space criteria.

\subsubsection{Maintenance Contractors (Non-Davis Bacon Work)}

Maintenance contractors performing work within WIPP lands without active direction from the WIPP STR shall submit the same documentation required of the Davis-Bacon contractors (see above). When applicable, contractors operating under the direction of the site STR provide, for approval, to the WIPP STR and WID Industrial Safety the following:

1. Written documentation that all electrical hand tools have been tested as defined in OSHA 29 CFR 1926.404 (b).

2. Training records or confirmation of safety training for all employees as defined in OSHA 29 CFR 1926.21. "Safety Training and Education."

3. Copies of MSDSs for each chemical to be brought on site or to the project by the subcontractor.

4. Approved job hazard analysis or work instructions for each segment of work.

\subsubsection{Waste Isolation Pilot Plant Responsibilities}




\subsubsection{Waste Isolation Division Procurement Services}

WID Procurement Services provides:

1. The WIPP safety rules and procedures for subcontractors (available on request from the LUC).

2. Specific safety requirements for construction subcontractors meeting the Davis-Bacon criteria (available on request from the LUC).

3. Copies of all subcontract purchase requisitions to the WID Industrial Safety Section.

\subsubsection{Waste Isolation Pilot Plant Subcontract Technical Representative Responsibilities}

The WIPP STR shall:

1. Interface with other site groups and subcontractors.

2. Identify potential safety and exposure hazards that may interfere with the subcontractor while on the project.

3. Require mitigating emergency response procedures relative to the scheduled work activities.

4. Initiate stop work orders when OSHA, Mine Safety and Health Administration (MSHA), or the WIPP safety rules are violated and report all stop work orders that impact subcontractors to the cognizant WID Procurement Services representative.

5. Adhere to the existing system for maintenance of records regarding accident investigations, near-miss observations, injuries, and illnesses.

6. Route all maintenance contractor (non-Davis-Bacon) submittals through the WID Environment, Safety and Health (ES\&H) Department for approval prior to commencement of work.

\subsubsection{Procedure for Reporting Accidents}

1. The WIPP site-specific procedure for reporting accidents will be used throughout the WLWA. All accidents involving injury or illness are required to be reported immediately to the CMR (first), the WIPP STR, the WIPP site medical personnel (according to WP 12-918, Reporting Occurrences in Accordance with DOE Order 5000.3B), and the individual's manager. 
2. Property damage caused by accidents shall be reported to the CMR then to the WIPP STR, who convey the information to appropriate management.

3. Subcontractors are required to post emergency numbers and ensure that such numbers are provided to all employees of lower-tier subcontractors.

4. No off-site authorities are contacted prior to contacting the WIPP STR.

5. Spills, releases to the environment, and other "off-normal" events are to be reported in accordance with WIPP procedures.

6. All information concerning injuries and/or illness involving their employees are required to be recorded on their OSHA $200 \mathrm{Log}$ or other appropriate record.

\subsubsection{Subcontractor Safety Procedures}

When stipulated in the statement of work, all subcontractors are required to include the following information in their bid package:

1. Medical surveillance and first aid plan

2. Electrical safety program

3. Hearing conservation program

4. Personal protection equipment program

5. Housekeeping program and inspection program

6. Hazardous waste disposal procedures

The statement of work for non Davis-Bacon subcontractors whose employees are under the direction of a WIPP STR is not required to contain the above requirements because employees of such subcontractors are subject to WIPP safety programs.

\subsubsection{Personal Protective Equipment}

Subcontractors are responsible for providing WIPP-approved personal protective equipment (PPE) to their employees. Any employee required to wear respiratory equipment must have prior medical approval from a physician to wear such type of equipment and be trained to wear it properly.

\subsubsection{Safety Meetings}

Subcontractors are required to conduct safety meetings, the frequency of which will depend on the nature of the project, but at a minimum of weekly. 


\subsubsection{Subcontractor Procedures}

Procedures of subcontractors will not conflict with the WIPP site-specific procedures. In cases wherein procedures of subcontractors conflict with those of the WIPP, the WIPP STR will seek assistance and guidance from the WID ES\&H Department.

\subsubsection{Housekeeping Inspections}

Subcontractor personnel (including lower-tier subcontractors) are required to conduct daily safety checks of areas where their employees are working. Any unsatisfactory conditions are reported immediately to the WIPP STR. Corrective actions will be taken immediately and documented on a daily safety inspection form.

Refuse and scraps that interfere with work flow and/or create fire hazards are required to be disposed of properly in a timely manner and not allowed to accumulate.

Subcontractors cannot block aisles, walkways, stairs, etc. The WIPP STR shall be notified prior to the erection of any barricades or other efforts by the subcontractor to prevent entry into areas. 



\section{CHAPTER 13}

\section{MAINTENANCE AND WORK CONTROL}




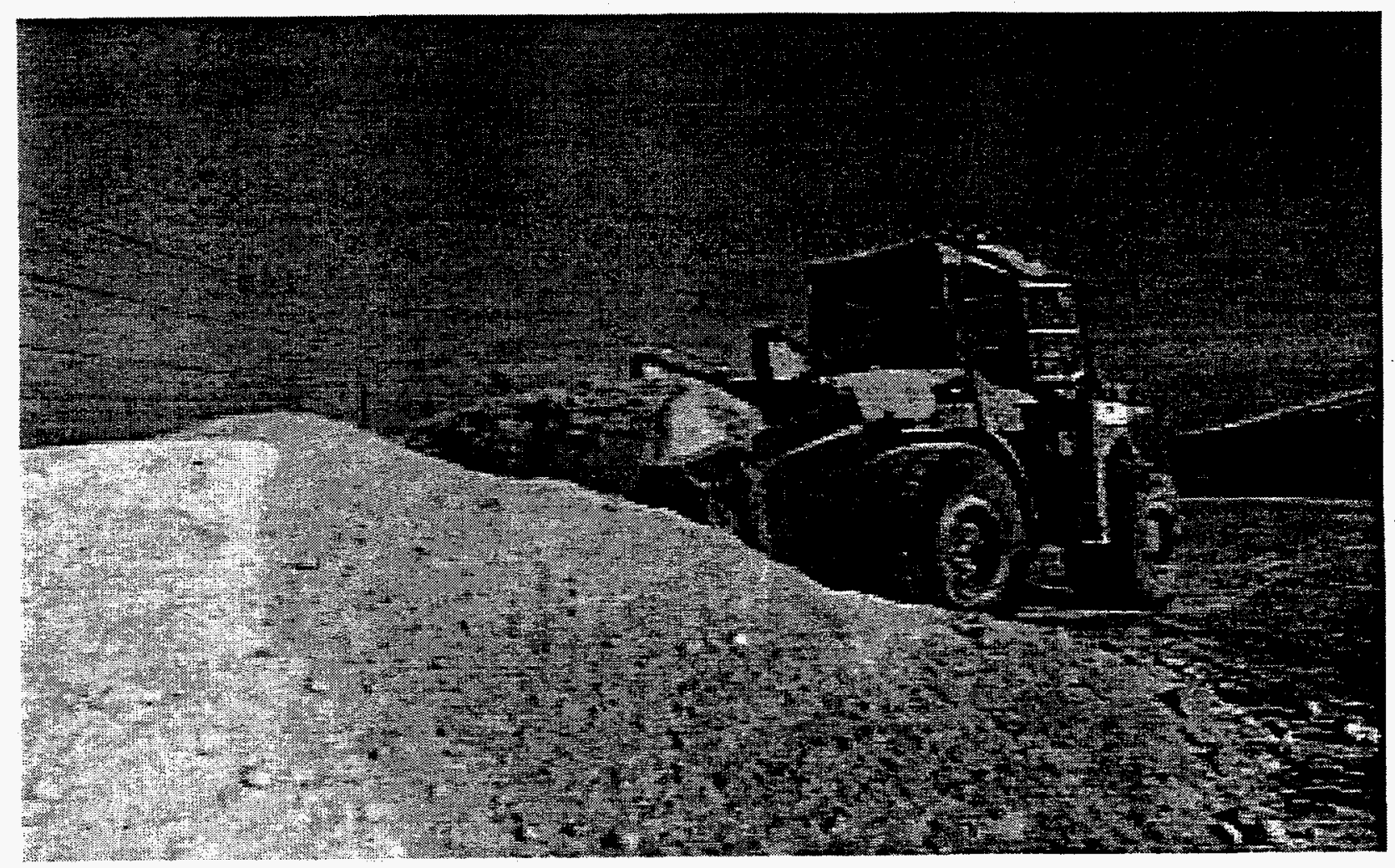




\section{CHAPTER 13 MAINTENANCE AND WORK CONTROL}

\subsection{INTRODUCTION}

Lands used in the operation of the WIPP are listed in one of two categories. The first consists of lands contained within the boundary of the WLWA. Included in this area are roads, groundwater monitoring well pads, reclamation sites, and storage yards. Lands used in the operation of the WIPP outside the WLWA boundary consist primarily of access roads to groundwater well pads and a few isolated reclamation areas. [Note: roads and well pads used in the operation of the WIPP are identified in Figure 13.1.] The maintenance management program for the WIPP facility is consistent with best management practices (e.g., DOE Orders, WIPP procedures) that pertain to the maintenance of properties in a manner that promotes operational safety, worker health, environmental protection and compliance, property asset preservation, and cost effectiveness, while meeting the programmatic mission.

\subsection{OBJECTIVES}

The DOE maintenance objective (scope) is defined as the preventive, predictive, corrective, and scheduled maintenance activities for facilities, equipment, and support infrastructure necessary to accomplish the WIPP mission.

The WID work control system controls maintenance activities. It ensures that maintenance activities are effective in maintaining safe and reliable facility operation. This system applies to all personnel doing maintenance activities at the WIPP.

The WID work order system is the central component of the control system for maintenance activities at the WIPP. The work order system ensures that jobs are identified, logged, planned, scheduled, performed, tested, and formally accepted and documented in a systematic manner.

\subsection{PLANNED ACTIONS}

A maintenance training program has been established through the central site training organization. The training organization supports maintenance training programs that meet the intent of established industrial guidelines and address specific WIPP needs.

The infrastructure and equipment of the WIPP is required to be maintained by a proper balance of preventive, corrective, and predictive maintenance; procedures and 
standards; and configuration management. Maintenance activities are controlled by the WID work control system to ensure a safe and reliable facility operation. The work order, submitted in accordance with Work Control Administration (WP 10-WC3002) and the Maintenance Operations Instructions Manual (MOIM), is the fundamental form used in the work order system for:

1. Job planning and analysis

2. Permits

3. Work performance standards

4. Priority system

5. Scheduling

6. Construction program interface

7. Post maintenance/modification testing

Maintenance activities in support of this LMP will be performed to the same criteria as established for the base facility (Property Protection Area). The expanded maintenance work scope as it pertains to land management activities includes, but is not limited to:

1. Maintenance of roads inside the WLWA

2. Maintenance of the WIPP railroad easement and the corresponding frontage road

3. Maintenance of DOE signs inside the WLWA

4. Maintenance of signs outside the WIPP boundary on properties used in the operation of the WIPP (e.g., North Access Road)

5. Maintenance of the North Access Road

6. Construction and maintenance of cattle guards inside the WLWA

7. Construction and maintenance of cattle guards outside the WLWA on roads used expressly for WIPP operations

8. Maintenance and oversight of the WIPP water line in accordance with contractual edicts between the City of Carlsbad and the DOE

9. Construction and maintenance of security/safety fences within the WLWA (e.g., the fence surrounding the Exclusive Use Area, and the fences that parallel the North and South Access Roads, that prevent livestock from wandering on the road) or at remote locations outside the WLWA used in the operation of the WIPP.

10. Construction and maintenance of groundwater surveillance well pads and corresponding access roads inside the WLWA. 
11. Construction and maintenance of groundwater surveillance well pads and corresponding access roads outside the WLWA. [Note: roads outside the WLWA, identified as part of the WIPP maintenance work scope are limited to those which are intended exclusively for WIPP-related activities. Road maintenance of existing easements or rights-of-way, not constructed expressly for the WIPP uses but used as convenient access routes for WIPP-related activities, is not the responsibility of the WIPP.] 


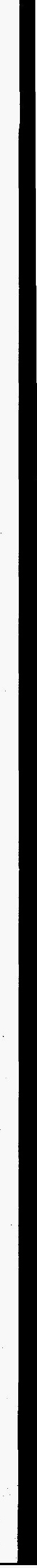




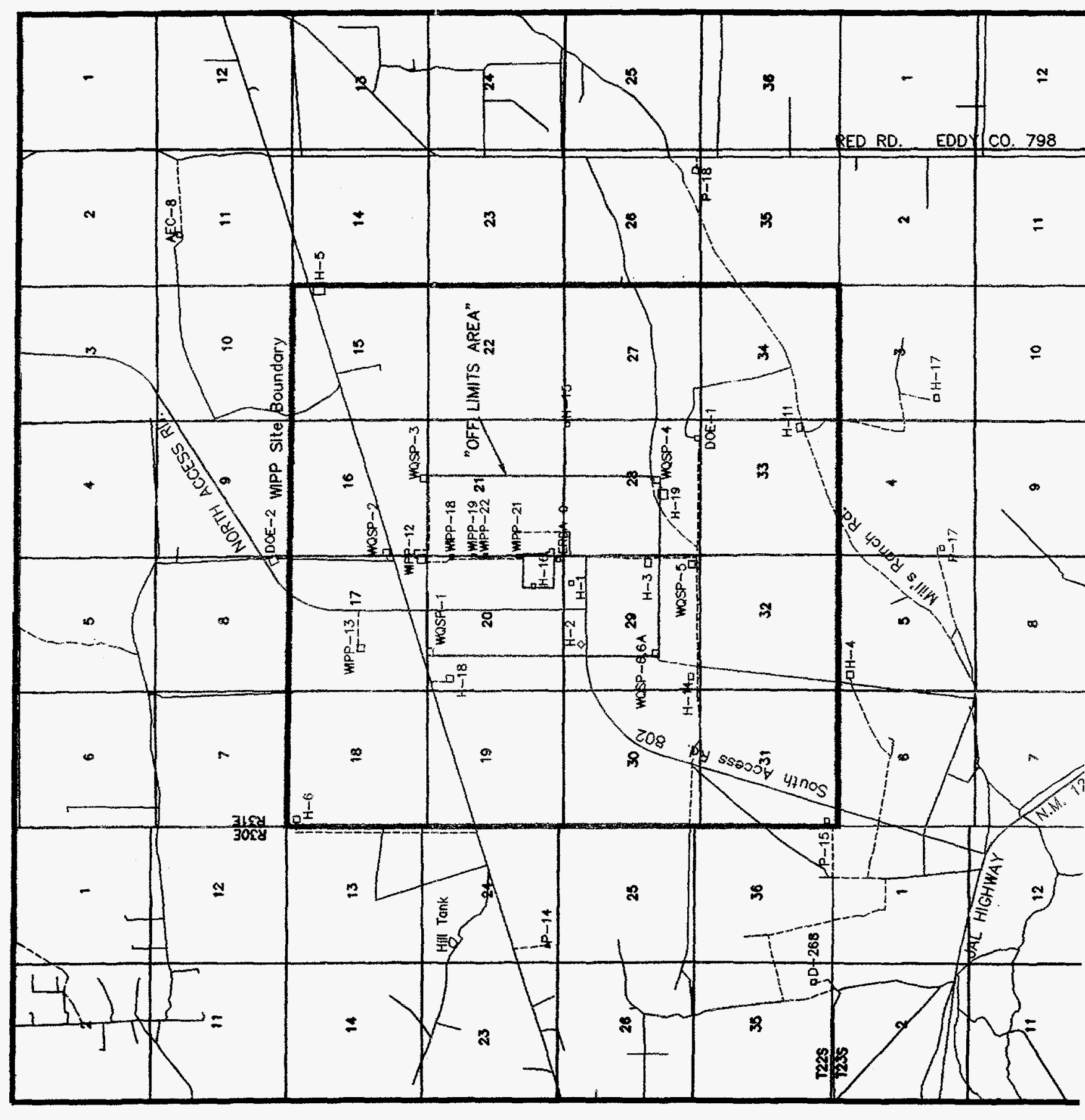




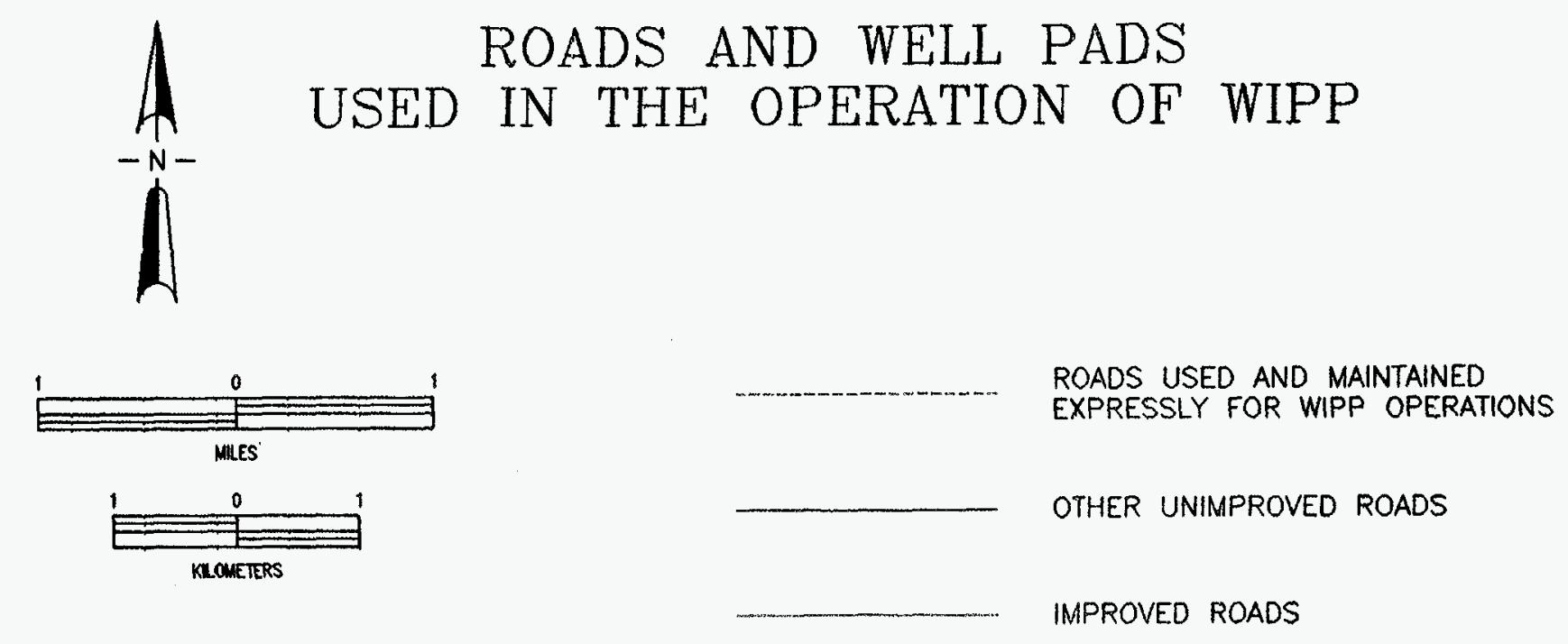

FIGURE 13.1 
APPENDIX A 



\section{APPENDIX A \\ LAND MANAGEMENT COUNCIL}

Land Management Planning

\subsection{SCOPE}

The WIPP Land Management Council provides policy guidance to the Department of Energy (DOE) in areas involving coordination of the management and oversight of lands included within the boundaries of the Waste Isolation Pilot Plant (WIPP) Land Withdrawal Area and those lands outside the WIPP boundary used in the operation of the WIPP site. This includes compliance with all applicable regulatory requirements relating to activities which occur or are likely to occur within the boundaries of those lands used in the operation of the WIPP. These include (but are not limited to) regulations referenced in the WIPP Land Management Plan (DOEWIPP 96-2151), Joint Powers Agreement(s) (JPA), and the U.S. Department of the Interior, Bureau of Land Managem ent (BLM) - DOE Memorandum of Understanding (MOU) incorporating all regulatory requirements and directives contained therein.

\subsection{PARTICIPANTS}

The Land Management Council shall consist of the following:

DOE Land Management Designee

WID Land Use Coordinator

Affected Stakeholder(s) - as appropriate (see Section 5.0)

\subsection{RESPONSIBILTIES}

1. Attend LMC meetings.

2. Evaluate and establish positions on issues or proposals brought before the LMC for consideration, and register individual concurrence or nonconcurrence.

3. Participate in matters that are presented to the Council for action.

4. Establish and maintain lines of communication among participants entities which, at any time, may have reason to utilize lands under the jurisdiction of the WIPP site.

5. Obtain recommendations and guidance from appropriate federal and state agencies. 


\subsection{Responsibilities (continued)}

6. Provide recommendations and guidance to federal and state agencies as appropriate.

7. Monitor DOE compliance with applicable implementation of new state and/or federal regulatory requirements as they pertain to lands under the jurisdiction of the WIPP project.

8. Review of any unusual occurrences involving potential or existing safety concerns, contamination release, environmental noncompliance, nonconformance(s) with the Safety Analysis Report, and the like as they pertain to land management concerns.

9. Other pertinent issue/policy agenda items.

\subsection{OPERATION}

1. Convening the LMC by the DOE or the LUC shall occur as issues related to land management arise, as defined in the Land Management Plan.

2. Consideration of issues related to land management will not proceed without prior notification to all members of the LMC (to include affected stakeholders).

3. Decisions by DOE affecting the vested interests or concerns of party/parties identified as "affected stakeholders" will incorporate comments from said parties as voting members of the LMC.

4. The LMC will track all Land Use Requests from inception to project culmination, to include modifications, longevity and/or decommissioning.

\subsection{STAKEHOLDERS/KEY EXTERNAL INTERFACES}

1. Agency for Conservation Archaeology (ACA)

2. City of Carlsbad, New Mexico

3. Eddy County

4. (New Mexico) Energy, Minerals, and Natural Resources Department (EMNRD)

5. Environmental Evaluation Group (EEG)

6. Forestry and Resources Conservation Division of EMNRD 


\subsection{STAKEHOLDERS/KEY EXTERNAL INTERFACES (continued)}

7. Historic Preservation Division of the Office of Cultural Affairs (OCA)

8. Lea County

9. Mills Ranch, Mr. J. C. Mills, Operator

10. New Mexico Department of Game and Fish (NMDG\&F)

11. New Mexico Environment Department (NMED) - DOEMIPP Oversight

12. (New Mexico) Office of Cultural Affairs (OCA)

13. Oil Conservation Division of the EMNRD (OCD)

14. Sandia National Laboratories (SNL)

15. Smith Ranch, Mr. K. Smith, Operator

16. (New Mexico) State Historic Preservation Officer (SHPO)

17. (New Mexico) State Land Office (SLO)

18. U.S. Department of the Interior, Bureau of Land Management (BLM)

19. U.S. Department of the Interior, U.S. Fish and Wildlife Service (USF\&WS)

20. (New Mexico) State Engineer Office

21. U.S. Federal Bureau of Investigation

22. (New Mexico) State Police

23. (New Mexico) Department of Agriculture

24. U.S. Department of Agriculture

25. Carlsbad Area Office (CAO) of the DOE

26. (U.S.) Department of Justice 

APPENDIX B 



\section{APPENDIX B}

\section{GUIDE FOR THE COMPLETION OF A LAND USE REQUEST}

Acceptance or denial of a LUR is contingent on the accuracy and completeness of the LUR submittal. A LUR submittal consists of three basic elements or steps. These are:

Step 1: The requestor(s) of specific projects is required to complete a detailed, narrative description of the proposed activities for evaluation by the LUC. The project abstract is required to contain the following:

- Disclosure of the names of all individual(s) and/or companies scheduled to perform the proposed action;

- The intent or purpose of the proposed action;

- Anticipated timelines for completion;

- Impacts on the WIPP that would result if the LUR for the proposed action was denied;

- Alternatives;

- Anticipated environmental impacts;

- Detailed reclamation/restoration plans.

Step 2: The requestor(s) is required to submit a properly completed ER (Attachment 1 to Appendix B).

Step 3: The requestor is required to provide a map (USGS 7.5 topographic, BLM land status, or WIPP generated) depicting the location(s) of the proposed action. 

BRIEF DESCRIPTION: (Include type of action, location, schedule, justification. Use separate attachment if necessary)

ENMRONMENTAL CONCERNS: Will the project/activity, either during construction or operation result in changes and/or disturbances in the following areas? Check "yes" if the proposed projectlactivity represents a commitment to a course of actions that would ultimately require a positive response to one or more of the questions below. Provide brief explanations for "yes" responses.

1. Air emissions

2. Liquid effluents

3. Solid waste

4. Hazardous constituents

5. Radioactive waste

6. Mixed waste (rad. \& haz.)

7. Chemical storage/use

8. Petroleum storage/use

9. Asbestos materials

10. Utility system

11. Clearing or excavation

No.

YES NO

$\square \square$

$\square \square$

$\square \square$

$\square \square$

$\square$ ㅁ

$\square \quad \square$

$\square \cdot \square$

$\square \square$

$\square \square$

$\square \square$

$\square \square$
- YES NO

12. Outside property protection area

13. Archaeologicalvultural resources

14. Noticeable increase in noise

15. Radiationftoxic chemical exposures

16. Pesticide/herbicide use

17. High energy source/environment

18. Transportation issues

19. Special status species/environment

20. Environment restoration site

21. Other (specify)

Explanation and qualification of specific "Yes" responses.

Are any waste minimization measures planned for this action? If yes, provide brief description of the measures planned.

Cl Printed Name

Signature

Date

"Required only if items 1213 and/or 20 are checked 'YES"

Land Use Coordinator (Printed Name)

Signature

Date 

APPENDIX C 



\section{MEMORANDUM OF UNDERSTANDING BETWEEN}

THE U.S: DEPARTMENT .OF ENERGY<smiles>[18NH2]</smiles>

THE U.S. DEPARTMENT OF INTERIOR 



\section{TABLE OF CONTENTS}

\section{MEMORANDUM OF UNDERSTANDING BETWEEN \\ THE U.S. DEPARTMENT OF ENERGY \\ AND \\ THE L.S. DEPARTMENT OF INTERIOR}

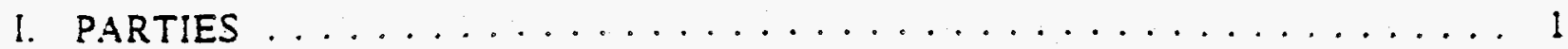

II. BACKGROUND AND PLRPOSE $\ldots \ldots \ldots \ldots \ldots \ldots \ldots \ldots \ldots$

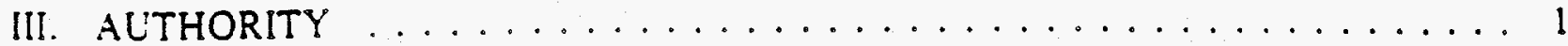

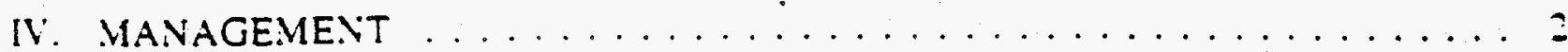

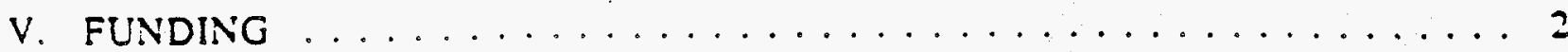

VI. RESPONSIBILITIES OF PARTICIPATING PARTIES $\ldots \ldots \ldots \ldots \ldots \ldots 2$

A. Cultural Resources . . . . . . . . . . . . . . . . 2

B. Grazing Management $\ldots \ldots \ldots \ldots \ldots \ldots \ldots \ldots \ldots \ldots$

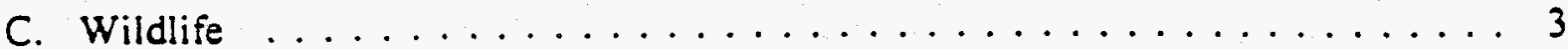

D. Fire Management $\ldots \ldots \ldots \ldots \ldots \ldots \ldots \ldots \ldots \ldots \ldots$

E. Mining and Gas and Oil Production $\ldots \ldots \ldots \ldots \ldots \ldots$

F. Realty/Lands/Rights-of-Way $\ldots \ldots \ldots \ldots \ldots \ldots \ldots \ldots \ldots$

G. Reclamation ..................... 7

VII. PUBLIC INFORMATION COORDINATION $\ldots \ldots \ldots \ldots \ldots \ldots \ldots$

vill. PATENTS AND TECHNICAL DATA $\ldots \ldots \ldots \ldots \ldots \ldots \ldots \ldots \ldots$

IX. REVIEW. AMENDMENT. AND TERMINATION $\ldots \ldots \ldots \ldots \ldots \ldots \ldots .8$

$\mathrm{X}$. EFFECTIVE DATE $\ldots \ldots \ldots \ldots \ldots \ldots \ldots \ldots \ldots \ldots$ 


\section{MEMORANDUM OF UNDERSTANDING \\ BETWEEN \\ THE U.S. DEPARTMENT OF ENERGY \\ AND \\ THE L.S. DEPARTMENT OF THE INTERIOR}

\section{PARTIES}

The parties to this Memorandum of Understanding (MOU) are the U.S. Department of Energy (DOE). represented by its Waste Isolation Pilot Plant (WIPP) Carisbad Area Office. and the U.S. Department of the Interior (DOI). represented by its Bureau of Land Management (BL.M). Roswell District Office.

\section{BACKGROUND AND PURPOSE}

The WIPP is authorized under Section 213 of the DOE National Security and Military Appiications of Nuclear Energy Authorization Act of 1980. Public Law (P.L.) 96-164. The WIPP is authorized for the express purpose of providing a research and development tacility to demonstrate the sare disposal of radioactive wastes resulting from the defense activities and programs of the Uinited States exempted from regulation by the Nuclear Regulatory Commission.

The WIPP Land Withdrawal Act of 1992. P.L. 102-579 ("the LWA"), withdrew 10.240 acres of land in Eddy County. New Mexico. from the operation of the public land laws and reserved those lands for the construction. experimentation. operation. repair and maintenance. disposal. shutdown. monitoring, decommissioning, and other authorized activities associated with the purposes of the WIPP as set forth in Section 213 of P.L. 96-164.

Section 4 of the LWA makes the Secretary of Energy responsible for the management of the withdrawal. consistent with the Federal Land Policy and Management Act of 1976. The LWA directs the Secretary. in consultation with the Secretary of the Interior and the state of New Mexico. to develop a land management plan (DOE/WIPP 93-004) for the use of the withdrawal area until the end of the decommissioning phase. It further directs the Secretary and the Secretary of the Interior to enter into an MOU to implement the management plan.

\section{AUTHORITY}

This MOU is entered into pursuant to the authority of. and is consistent with. the LWA. Further. it is consistent with and subject to certain other appropriate statutory authorities. including the Department of Energy Organization Act. P.L. 95-91; the Energy Reorganization Act of 1974. P.L. 93-438: and the Economy Act of 1932. as amended by P.L. $98-216$. 


\section{MANAGEMENT}

This MOU envisages direct communication between officials of the DOE and the BLM in consultation with other iederal and state land management agencies which are involved in managing the resources within or activities impacting the surrounding areas of the WIPP withdrawal area. This MOU sets forth the cooperative arrangements and procedures for addressing land management within the withdrawal area. These cooperative arrangements and procedures impiement the WIPP Land Management Plan for the withdrawal area and are consistent with the WIPP Land Management Plan's concept of multiple-use management.

The responsibilities and duties listed pursuant to this MOU relate to those snared by the DOE and the DOI. For additional land management issues not found in this MOL. consult the WIPP Land Management Plan.(DOE/WIPP 93-004).

This MOU will be administered on behalf of the DOE by the Manager. Carlsbad Area Office. P.O. Box 3090. Carlsbad. New Mexico 88221.

This MOU will be administered on behalf of the DOl by the District Manager. Roswell District Office. BL.M. P.O. Box 1397. Roswell. New Mexico 88201.

\section{FUNDING}

The details of the levels of runding to be furnished to one signatory organization by the other will be developed in specific interagency agreements, subject to the availability of funds. This MOU shail not be used to obligate or commit funds or as the basis for the transfer of tunds. The DOE and the DOI will provide each other munual support in budget justification to the Office of Management and Budget and in hearings before the Congress with respect to the progtams described in the WIPP Land Management Plan and implemented through this MOU.

\section{RESPONSIBILITIES OF PARTICIPATING PARTIES}

\section{A. Cultural Resources}

It is the intent of the DOE to manage cultural resources within the withdrawal area pursuant to Sections 106 and 110 of the National Historic Preservation Act. Archaeological Resource Protection Act. Native American Graves Protection and Repatriation Act. and applicable DOE Orders to ensure that scientific and sociocultural use by present and furure generations shall not be diminished.

1. The DOE agrees to:

a. Retain responsibility for management of cultural resources within the withdrawal area.

b. Inventory and evaluate cultural resources prior to surface-disturbing activities. 
c. Lise avoidance as the primary mitigation measure.

2. The DOI agrees to:

a. Provide recommendations to the DOE in developing mitigation measures when avoidance of historic property is not possible.

B. Grazing Management

The withdrawal area includes portions of two grazing allotments administered by the BLM. The DOE's intent is to continue current management practices.

1. The DOE agrees to:

a. Retain responsibility for grazing management decisions affecting the two grazing allotments within the withdrawal area.

2. The DOI agrees to:

a. Provide proposed grazing management changes and/or plans to the DOE for review and comment.

b. Provide grazing management of the grazing allotments within the withdrawal area in accordance with applicable grazing laws including the Taylor Grazing Act, the Federal Land Policy and Management Act. and the Public Rangelands Improvement Act.

c. Continue BLM-funded vegetative monitoring program to determine if range management goals and objectives established for the grazing allotments are being achieved. As a minimum. the monitoring program will include collecting data on acrual livestock use, wildlife habitat and population trends. degree of utilization of the key forage species. climatic conditions, and rangeland ecological conditions and trends.

C. Wildlife

The DOE intends to manage wildife habitat within the withdrawal area for ungulates. raptors. upland game. and any special-stans piant or animal species occupying the withdrawal area.

1. The DOE agrees to:

a. Retain responsibility for management decisions affecting wildlife habitat and the habitat of any special-stanus plant or animal species found occupying the withdrawal area. 
b. Continue with the BLM and the DOE Interagency Agreement No. 1422G910-A2-0016 - Raptor Research and Management Program.

c. Upon receipt of the draft copy of the recovery plan (see Part 2a. below), the DOE shall review. comment, and transmit the draft copy of the recovery pian back to the BL.M within 30 days.

?. The DOI agrees to:

a. Develop a recovery plan in cooperation with the U.S. Fish and Wildlife Service and appropriate state agencies for any threatened or endangered plant and animal species found occupying the WIPP withdrawal area to"ensure its success and survival.

b. Continue with the BLM and the DOE Interagency Agreement No. 1+22G910-A2-0016 - Raptor Research and Management Program.

c. Consult with the DOE to ensure that any range improvement developments (e.g.. installation of livestock watering units) will be designed to accommodate wildlife needs.

D. Fire Management

It is the intent of the DOE to provide a fire management program that will ensure a timely, well-coordinated. and cost-effective response to suppress wildfire within the withdrawal area.

1. The DOE agrees to:

a. Employ full suppression strategy of a wildfire within the withdrawal area by utilizing the WIPP incident commander to coordinate fire management activities.

2. The DOI agrees to:

a. Provide full fire-fighting support within the withdrawal area should the WIPP incident commander request such support.

b. Commit necessary additional fire suppression resources should local BLM fire suppression resources be insufficient. The additional resources to be committed will be negotiated based upon the severity and behavior of the fire.

E. Mining and Gas and Oil Production

It is the intent of the DOE to ensure that mining and gas and oil activities do not encroach upon the withdrawal area. Adherence to this MOU is crucial to protecting the repository trom inadvertent human intrusion. The WIPP is an offset owner to all gas 
and oil leases adjacent to the withdrawal boundary and will exercise the right to provide input on proposed activities of adjacent offset operators requesting an exception to applicabie New Mexico Oil Conservation Division (NMOCD) rules and regulations.

In accordance with Section $4(b)(5)(A)$ of the LWA. no suriace or subsurface mining or oil or gas production. including slant drilling from outside the boundaries of the withdrawal. shall be permitted at any time (including after decommissioning) on lands on or under the withdrawal.

In accordance with Section 4(b)(5)(B) of the LWA. existing rights under Federal Oil and Gas Leases No. NMNM 02953 and No. NMNM 02953C shall not be affected uniess the Administrator of the Environmental Protection Agency deterrmines, after consultation with the Secretary of Energy and the Secretary of the Interior. that the acquisition of such leases by the Secretary of Energy is required to comply with the disposal regulations or with the Solid Waste Disposal Act (42 U.S.C. 6901 et seq.).

1. The DOE agrees to:

a. Coordinate with the BLM to provide input and recommendations in determining a BL.M permit issuance for oil and gas extraction and mining activity on federal lands within one mile of the WIPP withdrawal boundary.

b. Provide the technical expertise to interpret. review. and verify oil and gas activity calculations performed by the BLM.

2. The DOl agrees to:

a. Forward applications for Permit to Drill and mining and reclamation plans to the DOE for review and comment in determining issuance of any oil and gas extraction or mining permit within one mile of the WIPP withdrawal boundary. The BLM shall resolve any DOE comments prior to approval of such applications and plans.

b. Include the following as a Special Condition of Approval for oil and gas activity on federal lands at 330 teet or closer to the WIPP withdrawal boundary:

(1) Ensure that the operator provides the BLM with drill site downhole vertical deviation surveys for each 500 -foot drilling interval.

(2) Provide the technical expertise to calculate well bore deviation at each 500 -foot interval of drilling to determine the degree of deviation and forward these results to the DOE for review and verification of cajculations.

(3) Require the operator, in accordance with the NMOCD Rule 111, to perform and provide the BLM a directional survey to establish bottom 
hole location on well bores that experience deviation angles of more than five degrees from vertical in any 500-foot interval.

(4) Require the operator to perform and provide the BLM a directional survey to establish bottom hole location on well bores when the total cumulative degrees of displacement. independent of direction, indicate that the well bore could deviate to within 100 feet of the withdrawal boundary. Should the directional survey indicate that deviation is toward the withdrawal boundary, the BLM would require a directional survey at 100 -foot intervals until such time as data would indicate that the bottom hole location at total depth would not exceed 10 degrees from vertical or could result in a bottom hole location less than 100 feet from the withdrawal boundary. Should deviation direction continue towards the withdrawal boundary during the BLM monitoring of the 100-ioot directional survey intervals. the BLM will require the operator to take corrective measures (e.g.. side tracking) or cease drilling activity.

(5) Provide the DOE the directional survey results that establish bottom hole location on well bores that experience deviation angles of more than five degrees from vertical in any 500-foot interval and on well bores when the total cumulative degrees of displacement, independent of direction. indicate that the well bore could deviate to within 100 feet of the withdrawal boundary.

c. Provide the DOE with completion. alternate use. and/or plugging and abandonment reports relevant to drilling, production. injection. and mining activity on federal lands within one mile of the withdrawal boundary.

F. Realty/Lands/Rights-oi-Way

Land use management within the WIPP withdrawal boundary is the sole responsibility of the DOE. It is the intent of the DOE to monitor any land use proposal affecting the withdrawal area.

1. The DOE agrees to:

2. Consult with the BLM regarding furure DOE right-of-way actions needed outside the withdrawal area.

b. Review and comment on applications and proposals received by the BLM for any land uses atiecting, but not solely contained within, the WIPP withdrawal boundary.

c. Submit comments relative to any land uses affecting, but not solely contained within. the WIPP withdrawal boundary to the BLM's Roswell District Manager. or their representative. within 30 days of receipt from the BLM. 


\section{The DOI agrees to:}

a. Forward applications and proposals for land uses affecting, but not solely contained within. the WIPP withdrawal boundary to the DOE.

b. Assume responsibility, when designated as the lead agency, for the preparation of the National Environmental Policy Act documentation for land uses affecting, but not solely contained within. the WIPP withdrawal boundary. The BLM shall obtain the review and approval of the DOE (the contributing agency) in regard to the BLM issuance of a Record of Decision.

c. Incorporate any DOE- and/or WIPP-specific compliance requirements when preparing documentation for land uses affecting, but not solely contained within. the WIPP withdrawal boundary.

G. Reclamation

The DOE intends to remrn land disturbed by the WIPP activities to a stable ecological state that will assimilate with the surrounding undisturbed ecosystem.

1. The DOE agrees to:

a. Reclaim land disturbed by the WIPP activities in accordance with the Environmental Protection Implementation Plan (DOE/WIPP 90-050); the Federal Land Policy and Management Act, 1976 (P.L. 94579); the WIPP Final Supplement Environmental Impact Statement (DOE/EIS-0026-FS, Jan. 90); the WIPP Final Environmental Impact Statement (DOE/EIS-0026, Oct. 80); EPA requirements regarding disposal regulations; fubure Environmental Impact Statements; and land withdrawal requirements.

b. Consult with the BLM in advance of reclamation activities to ensure compliance with applicable DOE reclamation commitments.

2. The DOI agrees to:

a. Review DOE-proposed reclamation actions to ensure compliance with applicable DOE reclamation commitments.

\section{PUBLIC INFORMATION COORDINATION}

Subject to the Freedom of Information Act. Title 5 U.S.C 552, decisions by either party on disclosure of information to the public regarding projects and programs developed pursuant to this MOU shall be made only after consultation between the parties. 


\section{PATENTS AND TECHNICAL DATA}

Appropriate patent and other intellecrual property provisions shall be included in interagency agreements and any other agreements entered into by the parties in order to impiement this MOU. DOE patent and intellectual property policies shall apply to any such work performed by a contractor (inciuding any subcontractor) which is funded in whole or in part by the DOE. Rights to inventions made by U.S. government employees shall be determined by the employing agency. .

\section{REVIEW, AMENDMENT. AND TERMINATION}

The DOE and the DOI. in consultation with other federal and state agencies involved in managing the resources within the withdrawal. shall review the MOU on an annual basis to determine whether it remains current and whether it effectively and appropriately implements the WIPP Land Management Plan for the WIPP withdrawal.

In the event that the DOE and the DOI determine that this MOU should be revised or amended. such revision or amendment shall be accomplished only upon written agreement between the parties. Any revisions or amendments to this MOU shall be developed in consultation with the state of New Mexico.

This MOU may be terminated by mutual agreement of the DOE and the BLM, or by either party upon a 30-day written notice to the other party.

This MOU shall remain in effect until the end of the decommissioning phase of the WIPP, as that phase is defined in the LWA.

\section{EFFECTIVE DATE}

This MOU shall become effective upon the latter date of signature of the parties.

\section{U.S. DEPARTMENT OF ENERGY}

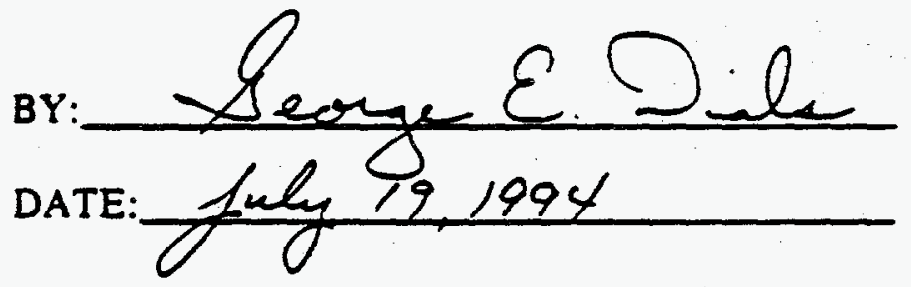

\section{U.S. DEPARTMENT OF THE INTERIOR BUREAU OF LAND MANAGEMENT}

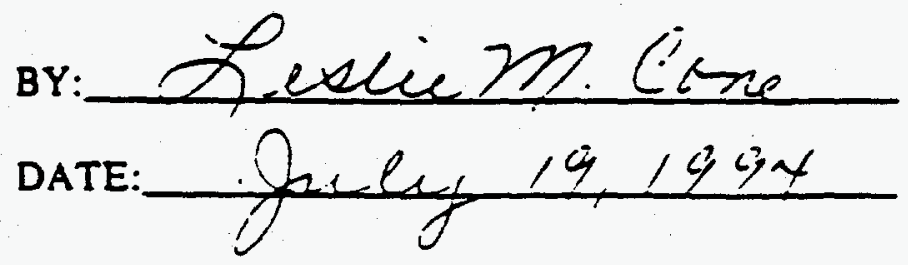



APPENDIX D 

WASTE ISOLATION PILOT PLANT

STATEMENT OF WORK

FOR

\section{THE BUREAU OF LAND MANAGEMENT}





\section{TABLE OF CONTENTS}

\section{STATEMENT OF WORK}

FOR

THE BUREAU OF LAND MANAGEMENT

RESPONSIBILITIES OF THE BLM $\ldots \ldots \ldots \ldots \ldots \ldots \ldots \ldots \ldots$

A. Cultural Resources $\ldots \ldots \ldots \ldots \ldots \ldots \ldots \ldots \ldots \ldots$

B. Grazing Management $\ldots \ldots \ldots \ldots \ldots \ldots \ldots \ldots$

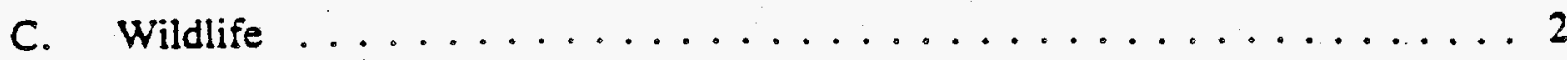

D. Fire Management $\ldots \ldots \ldots \ldots \ldots \ldots \ldots \ldots$

E. Mining and Gas and Oil Production $\ldots \ldots \ldots \ldots \ldots$

F. Realty/Lands/Rights-of-Way . . . . . . . . . . . 3

G. Reciamation ..................... 4 


\title{
WASTE ISOLATION PILOT PLANT
}

\author{
STATEMENT OF WORK \\ FOR \\ THE BUREAU OF LAND MANAGEMENT
}

The Bureau of Land Management (BL.M) shall perform the following specific tasks identified by the U.S. Deparment of Energy (DOE) as being necessary to the management of the Waste Isolation Pilot Plant's (WIPP) 16-section withdrawal area.

The parties to this Statement of Work (SOW) are the DOE. represented by its WIPP Carlsbad Area Office, and the U.S. Department of the Interior (DOI), represented by its BL.M, Roswell District Office.

This SOW supports the WIPP Land Management Memorandum of Understanding executed between the DOE and the DOI.

This SOW will be administered on behalf of the DOE by the Manager. Carisbad Area Office, P.O. Box 3090, Carlsbad. New Mexico 88221.

This SOW will be administered on behalf of the DOI by the District Manager, Roswell District Office, BLM, P.O. Box 1397, Roswell, New Mexico 88201.

\section{RESPONSIBILITIES OF THE BLM}

\section{A. Culnural Resources}

The BLM shall:

1. Provide recommendations to the DOE. within 30 days of request. in developing mitigation measures when avoidance of an historic property area is not possible.

\section{B. Grazing Management}

The BLM shail:

1. Provide proposed grazing management changes and/or plans to the DOE for review and comment.

2. Have the responsibility for all traditional administration of range resources afforded under the Taylor Grazing Act, the Federal Land Policy Management Act, and the Public Rangelands Improvement Act. Duties include, but are not limited to. the collection of grazing fees. project design and planning for development of range improvements, and development of Allotment Management Plans. 
c. Continue BLM-funded vegetative monitoring program to determine if range management goals and objectives established for the grazing allotments are being achieved. As a minimum, the monitoring program shall include collecting data on actual livestock use, wildlife habitat and population trends, degree of utilization of the key forage species, climatic conditions, and rangeland ecological conditions and trends.

C. Wildlife

The BLM shall:

1. Prepare in cooperation with the U.S. Fish and Wildifie Service and appropriate state agencies a recovery plan for any threatened or endangered plant and animal species found occupying the WIPP withdrawal area to ensure its success and survival.

2. Provide the DOE. within 30 days of report completion, a draft copy of the recovery pian for review and comment.

3. Consult with the DOE to ensure that any range improvement developments (e.g., installation of livestock watering units) will be designed to accommodate wildlife needs.

4. Continue with the BLM and the DOE Interagency Agreement No. 1422G910-A2-0016. Raptor Research and Management Program.

D. Fire Management

The BLM shall:

1. Provide full fire-fighting support within the withdrawal area should the WIPP incident commander request such suppor.

2. Commit necessary additional fire suppression resources should local BLM fire suppression resources be insufficient. The additional resources to be commined will be negotiared based upon the severity and behavior of the fire.

3. Negotiate with the DOE for monetary compensation required by the DOI for commitment of fire-fighting resources within the withdrawal area on a case-by-case basis.

E. Mining and Gas and Oil Production

The BLM shall:

1. Forward applications for Permit to Drill and mining and reclamation plans to the DOE within ten days of receipt for review and comment in determining issuance of any drilling or mining permit on federal lands within one mile of the withdrawal boundary. Drilling or mining permits for this area will not be issued by the BLM until DOE recommendations have been received. 
2. Include the following as a Special Condition of Approval for oil and gas activity on federal lands at 330 feet or closer to the WIPP withdrawal boundary:

a. Ensure that the operator provides the BLM with drill site downhole vertical deviation surveys for each 500 -foot drilling interval within 48 hours of completion of each 500-foot drilling interval. The BLM will provide the DOE with these drill site downhole vertical deviation surveys within three days.

b. Provide the technical expertise to calculate well bore deviation at each 500-foot interval of drilling to determine the degree of deviation and forward these results to the DOE within three days for review and verification of calculations.

c. Require the operator to perform and provide the BLM with a directional survey to establish bottom hole location on well bores when the total cumulative degrees of displacement, independent of direction, indicate that the well bore could deviate to within 100 feet of the withdrawal boundary. Should the directional survey indicate that deviation is toward the withdrawal boundary, the BLM would require a directional survey at 100 -foot intervals until such time as data would indicare that the botrom hole location at total depth would not exceed ten degrees from vertical or could result in a bottom hole location less than 100 feet from the withdrawal boundary. Should deviation direction continue towards the withdrawal boundary during the BLM monitoring of the 100-foot directional survey intervals, the BLM will require the operator to take corrective measures (i.e., side tracking)' or cease drilling activity.

d. Require the operator, in accordance with the New Mexico Oil Conservation Division (NMOCD) Rule 111, to perform and provide the BLM a directional survey to establish bottom hole location on well bores which experience deviation angles of more than five degrees from vertical in any 500-foot interval and on well bores when the total cumulative degrees of displacement, independent of direction, indicate that the well bore could deviate to within 100 feet of the withdrawal boundary.

e. Provide the DOE with the aforesaid directional surveys within three days of receipt and completion, alternate use, and/or plugging and abandonment reports within five days of receipt.

\section{F. Realty/Lands/Rights-of-Way}

The BLM shall:

1. Forward applications and proposals for land uses affecting, but not solely contained within, the WIPP withdrawal boundary to the DOE within ten days of the BLM receipt of a completed application.

2. Assume the responsibility, when designated as lead agency, for the preparation of the National Environmental Policy Act documentation for land uses affecting, but not solely contained within, the WIPP withdrawal boundary and any DOE and/or WIPP specific compliance requirements documentation. The BLM shall obtain the review and approval 
of the DOE (the contributing agency) of the aforesaid documents in determining issuance of a Record of Decision by the BLM.

3. Incorporate DOE- and/or WIPP-specific compliance requirements when preparing documentation for land uses affecting, but not solely contained within, the WIPP withdrawal boundary.

These requirements shall include at a minimum:

a. A safery plan that inciudes a job hazard analysis

b. A list of all hazardous materials

c. A description of methods used to manage and dispose of solid and hazardous waste

d. Detailed project design drawings to include specific areas of impact

e. A copy of their threatened and endangered species review (wildlife study)

f. A copy of the archaeology study

\section{G. Reclamation}

The BLM shall:

1. Within ten days of receipt from the DOE, review and comment on the DOE proposed reclamation actions to ensure compliance with applicable DOE reclamation commiuments.

\section{U.S. DEPARTMENT OF ENERGY}

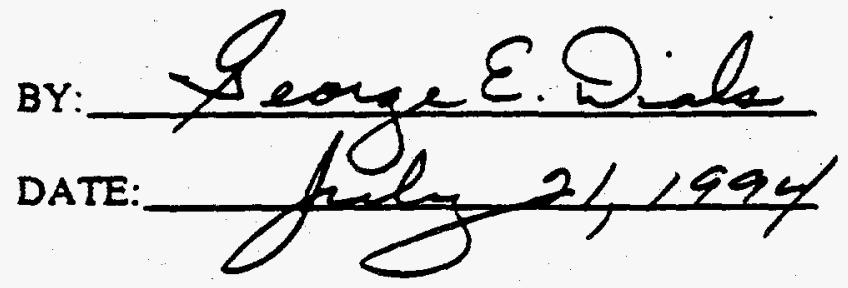

\section{U.S. DEPARTMENT OF THE INTERIOR BUREAU OF LAND MANAGEMENT}

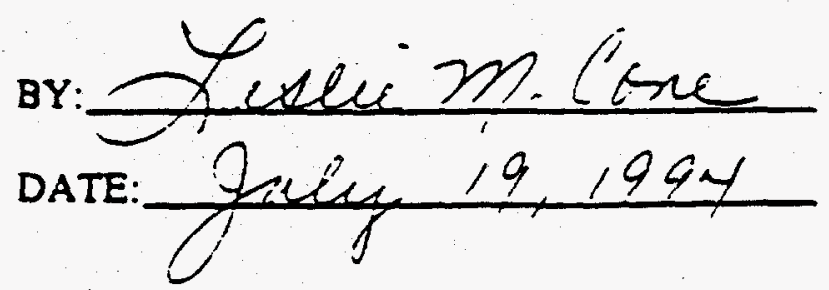



APPENDIX E 



\section{INTERAGENCY AGREEMENT NO. \\ betreen the \\ DEPARTIENT OE ENERGY \\ and the \\ BUREAO OF LAND MANAGEMENT}

\section{Rapror Research and Management Program}

Agreement No. 1422G910-A2-0016

\subsection{BACKGROUND}

This Interagency Agreement is pursuant to Appendix 3 of the Memorandum of Understanding (MOD) \#MM-6-34, dated October 26, 1990, between the United Staces Department of Energy (DOE), Waste Isolation Pilot Project (WIPP) Project Site Office (WPSO) and United States Deparement of Incerior Bureau of Land Management (BLM). Roswell District, Carlsbad Resource Area Office (CRA). Appendix 3 prescribes management direction for the maintenance and protection of wildife resources, including raptors. This Agreement defines the relationship and responsibilities of the BLY and the DOE/NPSO to expand the existing cooperative raptor and wildlife studies. The BLY will provide funding to expand the ongoing raptor/wildlife research program, and to engage in an on-the-ground sharing of resources to accomplish this effort.

The area has been designated as the Los Medanos Raptor Study Area which lies in Eddy and Lea counties of soucheastern New Mexico. This is an area idegefied as having a significancly dense and

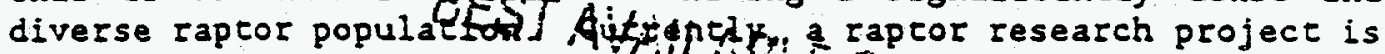

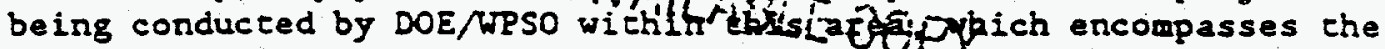
proposed 16 section withdrawal area for the WIPP sice and a large area of outlying land administered by the BLY. These research efforts have been ongoing for the past nine years, and have been funded by the DOE. The research has focused on the gachering of base line biological daca, describing the behavior, territoriality, and life history of the Harris Hawk and other species. As a, means of continuing and expanding this research program, while maintaining research continuity, the BLY will assist the DOE with funding and provide assistance in the collection of biological data.. (i.e. species diversity, nesting sites, high use area, etc.) necessary to amend the current CRA Resource Management Plan (RMP), and to develop a new raptor Habitac Management Plan (HMP) for the area.

In sumary, this cooperative effort will expand the monitoring and research to include potential short and long term impacts to all rapeor populacions and ocher wildlife species, and will more effectively focus on the raptor research needs of both agencies necessary to derive specific management direction. The BLY intends to expand the size of the Los Medanos study area, and to establish a raptor advisory comittee to assist in the development of protocols and procedures to reduce impacts to wildife species within the Los Medanos study area. The DOE/WPSO will assist in the development of these research protocols and of future HMPs for the area. 
1. To identify and map active nest sites and high use areas (cree groves, large wesquites w/nests, etc.) within the established boundaries of the Los Medanos study area in order to mitigate potential negative impacts accrued from land surface uses.

2. Establish wildlife management objectives for the area based on the research findings, and incorporate into the Carlsbad RMP amendment.

3. Base line data will be collected for the development of a Los Medanos Raptor HMP which will be initiated starting in FY95.

4. An overall raptor species list will be compiled from these efforts as well. It is already known, based on confirmed sigheings, that some endangered specits occur within or frequent the Los Medanos study area.

5. To establish an advisory committee for the designated raptor study area, to suggest research protocol, to review research proposals, and to ensure proper research techniques are practiced. However, approval of research proposals will not be the authority of this committee. The BLY and DOE will each assign at lease one member to the advisory comictee. Other members will include representative(s) from the New Mexico Department of Game and Fish, the US Fish and Wildlife Service, conservation groups, professional raptor research organizatiobs and the interested public.

\subsection{STATEMENT OF WORK}

A. The DOE/TPSO agree ro:

1. Denote active nest sites and high use areas for wildife on 7.5 minute topographic maps.

2. Monitor population dynamics, focusing mainly on recruicuent into the population, and home range size.

3. Monitor behavioral activities of family groups and single nature and immature birds.

4. Band all captured birds in order to track their long range migration through band recovery.

5. Atcach radio celenetry to a maximum of 10 birds in FY 92 (as permits allow) to monitor vinter and sumer range, home ranges and territories, and locate nesting sites and high use areas.

6. Take blood samples fron nestling(s) and adule(s) for analysis. The blood will be analyzed for concaninants (i.e. organophosphares, hydrocarbons, radionuclides, ecc.). 
7. Construct augmentation facility for the release of rehabilitated raptors, working in conjunction with licensed wildlife rehabilitators.

8. Sumarize the findings in responsibilities 1.7 which will be the basis for meeting the research needs idencified in Part 2.0., objectives.

9. Provide the CRA, with a yearly sumary report of the research findings. This report should include banding records, results of blood sampling, a 7.5 minute topographic nap identifying raptor nests and high use areas, and a complete list of all species occupying the Los Medanos study area.

B. The BLY agrees to:

1. Provide 7.5 minute topographic maps associated with the study area.

2. Provide personnel support, when available, to assist with on : the ground efforts being conducted by. WPSO employees.

3. Provide necessary clearances required for the development of future wildlife habitat enhancement projects. These projects way be established within the proposed 16 section DOE land wichdrawal or along pouble Eagle water line right-of-way.

4. Share nest location and behavioral information and fieid note data relevant to the cooperative studies.

\subsection{REPORTS}

A yearly report sumarizing the research findings including notations of active nest sites/high use areas, fledgling success, etc., shall be submitted by DOE/WPSO to the CRA after the monitoring seasons are complete. This report is due at the end of the fiscal year.

\subsection{PAYMENT}

As monies become available, a percentage of the tocal BLM allocated funds for this program shall be paid. The method for reimbursement will be via receipt of the SF 1081. The remaining percentage will be paid upon receipt and subsequent approval of the yearly summary report to be submitted at the end of the fiscal year.

The address for submission of the completed forms, progress reports, draft and final reports, etc. Is:

Bureau of Land Managenent

Attr: John Sherman

P.O. Box 1778

Carlsbad, NM 88221 


\subsection{TERMINATION}

This agreement shall become effective upon the dace of last signature and shall remain in effect for five consecurive years from that effective date. The agreement shall be reviewed on an annual basis for consideration of the project's effectiveness in meeting the specific goals and to ensure that the requirements still exist.

The BLM may terainate this agreement upon thirty (30) days written notice of such temination. The DOE/WPSO shall be reimbursed for commitments extending beyond the effective date of termination to a dace not later than the dace upon which the agreement would have explred if not terminated under this paragraph, which the DOE/WPSO, in the exercise of due diligence, is unable to cancel. Paywents under this agreement, including payments under this article, shall not exceed the ceiling amount elsewhere specified in this agreement.

7:0 ADMINISTRAIION.

1. BLY:

The Contracting officer responsible for this contract is:

Peggy Dabb

New Mexico Stace office

P.O. Box 27115

Santa Fe, NM 87502-0115

(.505) $438 \cdot 7638$

The Contracting Officer's Representative (COR) will be:

John Sherman

Carlsbad Resource Area

P.O. Box 1778

Carlsbad, NM 88221

(505) 887.6544 
2. DOE/WPSO:

The Contracting officer is:

Ona M. Bellino

U.S. Department of Energy

Contracts and Procurement Division

P.0. Bcx 5400

Albuquerque, NM 87185

(505) $845-6156$

The Project Manager is:

Arlen $\mathrm{E}$. Hunt

Waste Isolation Pilot Plant

WIPP Project site Office

P. O. Box 3090

Carlsbad, IM 88221

(505) 887-8101

\subsection{AUTHORIIY}

This agreement is entered into pursuant to the Authority of the Economy Act, 31 U.S.C. 1535.

U.S. Department of the Interior
Bureau of Land Management

New Mexico Stare Office

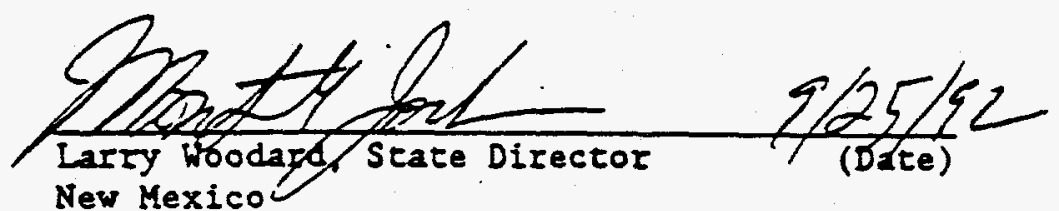

U.S. Departmedt of Energy

Waste Isolation Pilot Project

WIPP Project Site office

$\frac{\text { Ohea M. Relless } 9 / 25 / 92}{\text { Ona Bellino, Contracting Officer (Date) }}$ 
APPENDIX F 
MEMORANDUM OF UNDERSTANDDG

BETWEEN THE

UNTIED STATES DEPARTMENT OF ENERGY

AND TRE

NEW MEXICO DEPARTMENT OF PUBLIC SAFETY

CONCERNING

MUTUAL ASSISTANCE AND EMERGENCY MANAGEMENT

THIS MEMORANDUM OF UNDERSTANDING (MOU) is between the United States Deparmeal of Energy. (DOE), represented by the Albuquerque Field Office (AL). and the State of New Mexico (State), represented by the Deparmeat of Public Safety (DPS).

WHEREAS, both parties have cerrain responsibilities for protecting workers. the general public. the environmeat and properiy; and

WHEREAS, both paries have developed and maintain capabilities to accomplish these respective responsibilities; and

WHEREAS, both paries recognize that developing and maintaining a program of mutual assistance will eahance each's ability to accomplish theif respective responsibilities in a more effective and efficieat manner. and

WHEREAS, both parties are willing to enter into this MOU; and

WHEREAS, the DOE is authorized to enter into this agreement by Public Law 9591: and

WHIEREAS: the DPS is authorized to enter into this agreement on the behalf of the State to the extent provided by Section 74-4B-1 et seq.. NMSA 1978.

NOW. THEREFORE, it is understood and agreed by the paries as follows:

1. General:

a. References:

The DOE Order S500.1B. EMERGENCY MANAGEMIENT SYSTEM

The DOE Order 5500.2B. EMIERGENCY CATEGORIES, CLASSES. AND NOTIFCATION AND REPORTING REQUIREMENTS

The DOE Order 5500.3A. PLANNING AND PREPAREDNESS FOR OPERATIONAL EVIERGENCIES 
The DOE Order. 5500.4 . PUBLIC AFFAIRS POLICY AND PLANNING REQUIREMENTS FOR EMERGENCIES

The DOE Order. 5000.3A. OCCURRENCE REPORTING AND PROCESSING OF OPERATIONS INFORMATION

The DOE Order. 5530.3. RADIOLOGICAL ASSISTANCE PROGRAM

The DOE Order. 5530.6. FEDERAL RADIOLOGICAL MONITORING AND ASSESSMENT CENTER (Draft, dated May 30. 1991)

New Mexico Hazardous Materials Emergency Response Plan and Procedures manual. December 1989.

Radiological Emergency Response Planning and Preparedness. (44 CFR. Par 351)

The DOE Order 5300.1B. TELECOMMUNICATIONS

The DOE National Security Emergeacy Preparedness (NSEP) Telecommunications Procedural Guide, dated January 10. 1990

The Federal Radiological Emergency Response Plan (50 F. R. 46542, November 8, 1985)

Chapter 74, Article 4B. NMSA 1978, "Emergency Management Act"

Chapter 74. Article 4E. Sections 1 through 9. NMSA 1978. "Hazardous Chemicals Information Act"

Chapter 12. Article 10. Sections 1 through 10. NMSA 1978, "State Civil Emergency Preparedness Act"

b. Definitions:

(1) Sandia National Labomaties (SNIL): A DOE facility locared on Kirtand Air Force Base (KAFB). operated for the DOE by Sandia Corporation.

(2) Ross Aviation Inc (ROSS): A DOE facility located on KAFB. from which aireraft are operated for the DOE.

(3) The Inhalation Toxicology Research Instiuse, (ITRD): A DOE facility located on KAFB. operated for the DOE by the Lovelace Biomedical and Environmental Research Iostitute.

(4) The Kinland Area Office (KAO): A DOE facility located on KAFB. which is the DOE office responsible for administering the contracts for ROSS. SNL. and ITRI. 
(5) The Waste isolation Pilos Plan (WIPe): A DOE facility located in Eddy County. New Mexico. operated for the DOE by the Westinghouse Corp.

(6) The Los Alamos Narional Laboratory (LANL): A DOE facility located in Los Alamos County, New Mexico. operated for the DOE by the University of Califomia.

(7) The AL: The DOE Albuquerque Field Office.

(8) The Al comolex: The complex of buildings located on the corner of $H$ and Pennsylvania streets on KAFB, which houses the AL.

(9) The Los Alamos Area Office (LAAO): The DOE office responsible for administering the contract between DOE and the University of Califoraia for the operations of LANL.

(10) Hazardous Materiais (HAZMAT) Response: A response to an actual or potential emergency or incident involving hazardous materials.

(11) DOE Emergency Manager: The DOE Emergency manager is the director (DOE or DOE contractor) of the emergency management team in the Emergeacy Operations Center (EOC) of a DOE facility.

(12) DOE Incident Commander: The DOE Incident Commander is the DOE or DOE contractor on-scene director of emergency operations.

(13) The AL Operations Center: The AL. 24 hour point of coatact.

(14) The Depanment of Public Safety (DPS): The stare ageacy. through the Cabinet Secretary, that has the final authority to administer the provisions of the state Emergeacy Management Act.

(15) The Emergency Manarement Bureay (EMB): The organization within the DPS whose function it is to coordinate state planning and responses where more than one state agency is involved. to easure the citizens of New Mexico are protected from natural and man-made incidents. accidents. and disasters. This entity is also responsible for the state's EOC.

(16) State Emergency Response Officer (ERO): A state police officer trained in hazardous material aceident evaluation and emergency response. When the State Hazardous Materials Emergency Response Plan is activated. this 
individual serves 25 a central coordinator to direct response functions of responsible state agencies.

(17) Distriel Emergency Besponse Officer (ERO): A state police officer trained in hazardous material accident evaluation and emergency response who acts as the on-scene coordinator for accidents/incidents that occur in his/her district.

c. This MOU is entered into on bebalf of the DOE by the Manager. AL. and on bebalf of the State by the Cabinet Secretary of the DPS, to the exteat the DPS is authorized to eater into this agreement by Chaprer 74, Aricle 4B. NMSA 1978.

d. The provisions of this MOU apply to any actual or potential emergency or incident that:

(1) Involves a significant threat to empioyees of the AL. KAO. SNL. ROSS. LANL. LAAO, WIPP. ITRI, other DOENDOE. contractor personnel. or the general public:

(2) Involves property under the control or jurisdiction of either the DOE or the State:

(3) Involves a threat to the environmeat which is reporable to 20 off-site agency;

(4) Requires the combined resources of the DOE and the State to resolve:

(5) Requires a resouree that the DOE has which the State does not have, or a resource that the State has which the DOE does not have. to resolve: or

(6) lavoives any other incident for which a joint determination has been made by the DOE and the state that the provisions of this MOU will apply. This desermination shall be a joint determination made by the DOE and State ERO on dury, or the Director of the State EOC.

e. Backgrouad:

The AL has the responsibility for ensuring the safe transportation of DOE special auclear materials and transuranic waste throughout DOE Radiological Region IV. which encompasses the state of New Mexico.

Radiological Emergeacy Planning and Preparedness (44 CFR 35i) assigns to the DOE the responsibility to provide emergency response resources in the event of a major radiological emergency. Inbereat in this responsibility and as delineased in the Federal Radiological Emergency 
Response Plan (50 F. R. 46542. November 8, 1985), is the immediate reporting and response to emergency situations which could possibly endanger the safety of the inbabitants or the envirooment of New Mexico.

The nature of the work at some of the DOE facilities within the state creates the potential for on-site releases that have the potential of adversely affecting non-DOE areas and people. This situation promotes the need for close and professional cooperation between the DOE and State emergency planners and response personnel to effectively control incidents and accidents that might occur.

f. The DOE and the State do hereby expressly waive any and all ciaims against each other hereto for any loss. damage, personal injury. or death occurring in consequence of the reasonable performance of this MOU.

g. The DOE will coordinate with the DPS on response actions to a radiological accident or any other incidents involving DOE material or personnel.

2. Specific:

2. Emergency Management:

(1) The DPS shall:

Permit qualified and security cleared members of the DOE emergency management community identified by the Office of Emergency Plans and Operations. DOE, Al, access to the State EOC for the purpose of:

(a) Coordinating communications functions:

(b) Evaluatiag and maintaining communications capabilities:

(c) Participating in exereises:

(d) Link the State's High Frequency (HF) radio communications network with the DOE; and

(e) Assisting the State during radioactive materials accidents that require joint operations or the use of the DOE Radiological Assistance Program (RAP) team.

At the request of the DOE. cordon off segments of the state highway system as may be necessary for the landing of DOE aireraft that are responding to incidents or accideats pursuant to the provisions of this MOU. 
During an actual emergency permit DOE access to any appropriate warning networks. if necessary, which the State currently has available or may develop in the future. Specific details and justifications for the needed access will be provided to the State by the DOE at the time of the eveat.

Retain Incident Command authority for HAZMAT, radiological. or high energy release incidents occurring outside DOE property, usilizing such DOE officials as may be appropriate as advisors.

Maintain liaison with the DOE, through the EMB. regardiag State emergency planaing. preparedness. and response programs, and provide accurate and timely information to the DOE and public during emergency conditions.

However. the DOE may refuse requests from the State which would impede or interfere with the DOE's ability to meet its statutory responsibilities.

\section{(2) The DOE Shall:}

Permit qualified and DOE security cleared members of the State Emergency Managemeat community identified by the EMB access 10 DOE's EOCs for the purpose of:

(a) Coordinating communications functions:

(b) Eraluating and maintaining communications capabilities:

(c) Paricipating in exercises:

(d) Coordinating activities on the behalf of the State in the event of a radiological related emergency: and

(e) Coordinating activities on behalf of the State during radioactive Materials accideats that require joint operations or the use of the DOE RAP team.

Pay for DOE security clearances for up to three mernbers of the State Emergency Management community who will have aceess to the DOE EOCs.

Consult with the DPS in the preparation of emergency assessments and preparedness programs. and provide technical advice and assistance within the scope of the DOE's activities.

Retain control over emergency planning activities relating to radioactive materiais as delineated in the 
Federal Radiologieal Emergeacy Response Plan (50 F. R. 46542. November 8, 1985).

During an actual emergency, permit the State access to any appropriate warning networts. if necessary. which the DOE curreatly has available or may develop in the future. Specific details and justifications for the needed access will be provided to the DOE by the State at the time of the event.

Panicipate in the sesrch and recovery operations for nuclear materials. weapons, devices and transuranic waste involved in an incideat.

Retain Incident Command authority for hazardous materials. radiation or high energy release incidents occurring on DOE property, utilizing such state officers as may be appropriate as advisors.

Maintain liaison with the EMB regarding DOE emergency planning. preparedness. and response programs, and provide accurate and timely information to the DPS and public during emergency conditions.

Provide equipmeat and authorizations for all communications required by DOE for DOE/State mutual aid for emergency communications.

However. the State may refuse requests from the DOE which would impede or interfere with the State's ability to meet its statutory responsibilities.

Keep the State notified of all emergency events as speciñed in e. below.

b. Training:

(1) Annually, the DOE will provide orientation traning to State emergency response personnel on the hazards and emergency response procedures of DOE sites. Anoually. the State will provide orientation training to DOE emergency response personnel on the hazards and emergency response procedures of the State. Each of the paries will bear the cost of providing training to the other party.

(2) The DPS and AL will inform each ocher of emergency management training programs that are being conducted that personnel of the other party are eligible to atsend.

(3) The DOE will provide to the State and the State will provide to the DOE any training which is mutually agreed upon. 

with potential for loss of containment or confinemeat integrity.

(4) Attached to this MOU is a matrix containing the telephone numbers of both the DOE and the State that shall be used in making all notifications required by this MOU, plus some otber telephone numbers relative 10 DOE and State emergency management. This attachment will be revised annually by the parties idencified in $g$. below.

f. Public Information Coordination:

Consisteat with the Freedom of Information Act (S U.S.C. 552). procedures for the timely relesse of information to the public regarding any emergency response or preparedness activities under this MOU will be made following consultation between DOE and DPS representatives.

8. Administration:

This MOU will be administered on behalf of DOE by the Area Manager. KAO. Administration on bebalf of the DPS, will be the Director, EMB.

h. Security:

Except for the aceessary access that is allowed to the " $Q$ " cleared members of the State Emergency Managemeat commuaity in conjunction with their participation in the DOE EOCs during emergencies and/or emergency preparedness exereises. nothing in this MOU authorizes access to or disclosure of classified information required to be protected in accordance with federal law or regulations in the interest of axional security. DPS agrees to comply with. and to assure that all of its personnel participating in activities under this MOU comply with all applicable security regulations and requirements of the DOE.

i. Other:

(1) Command and Control:

The DOE and the State will use the National Interagency Incident Management System (NIIMS), Incident Command System (ICS). which is the State's standard command and control system, during joint emergency operations. 
(2) Nothing in this agreement negates or supersedes any other agreements between the DOE and the State.

3. Anti-Deficiency:

2. Nothing in this MOU commits the DOE to expend funds which have not been authorized by the U. S. Congress.

b. Nothing in this MOU commits the State to expend funds which have aot been authorized by the New Mexico State Legislature.

4. Term, Modification and Termination:

a. This MOU will become effective on being signed by the DOE and the DPS.

b. This MOU may be terminated by mutual agreement of the DOE and the DPS, or by either party upon a 30 day written notice to the other party.

c. This MOU will be reviewed annually by the parties identified in 8 . above and may be modified by written agreement between the DOE and the DPS.

Accepted on behalf of:

The DOE:

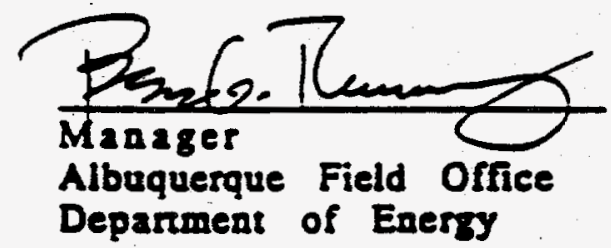

$3 / 3 / 92$ Date

Albuquerque Field Office

Deparment of Enerzy

Attachmeat
The State:

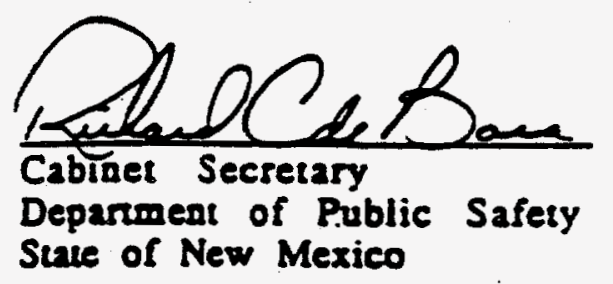

$\frac{3-1}{D a t}$ 
TOTHE

MUTUAL ASSISTANCE AND EMERGENCY MANAGEMENT

MEMORANDUM OF UNDERSTANDENG

BETWEEN THE DOE AND THE NEW MEXICO DEPARTMENT OF PUBLIC SAFETY

NOTIFICATION TEIEPHONE NUMBERS

EMERGENCY

NOTIFICATION

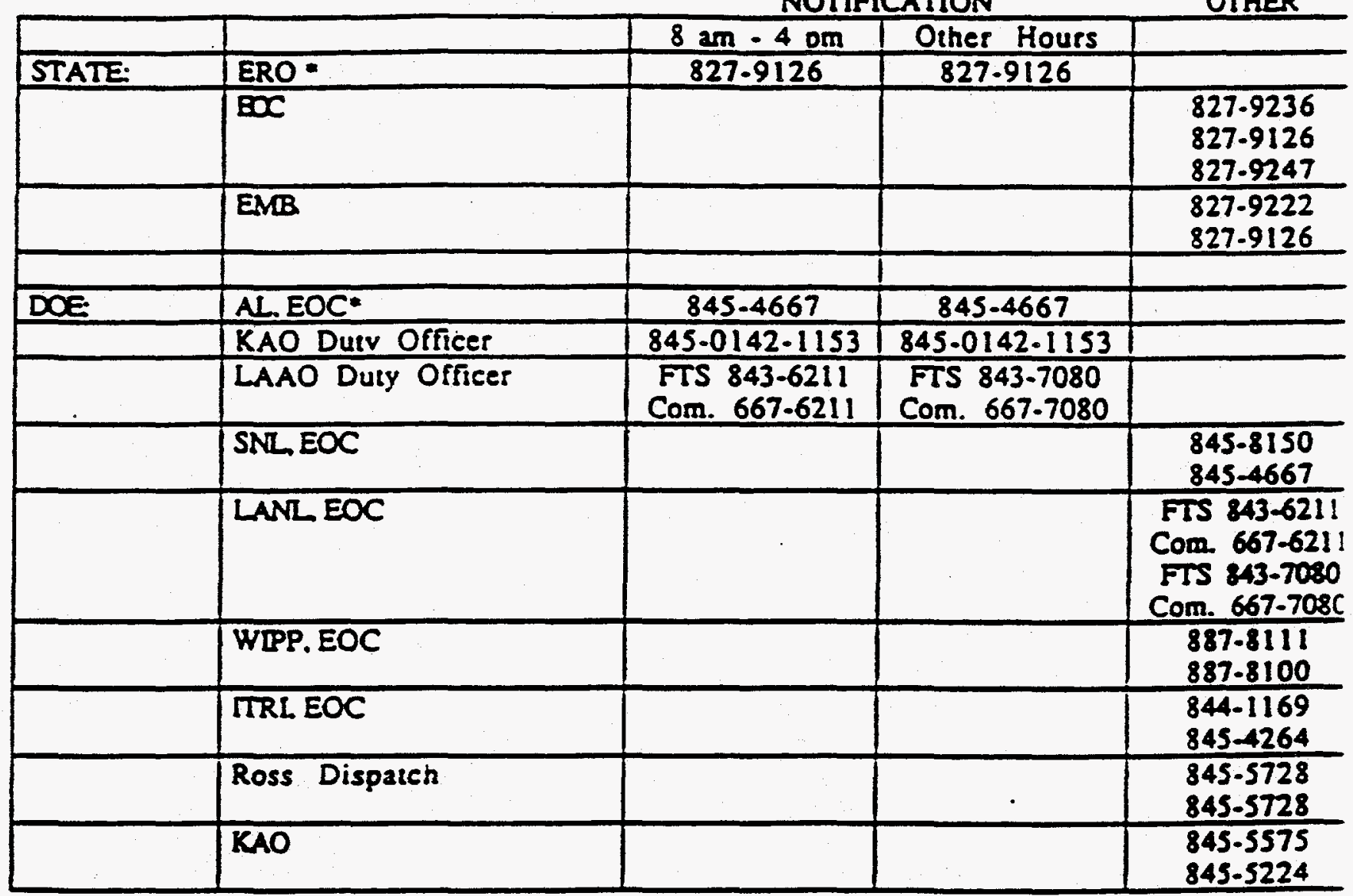

- First Notification

$\begin{array}{ll}\text { EOC } & \text { - Emergency Operations Ceater } \\ \text { EMB } & \text { - Emergency Management Bureau } \\ \text { ERO } & \text { - Emergeacy Response Officer } \\ \text { DEE } & \text { - Depanment of Energy } \\ \text { AL } & \text { - Albuquerque Field Office } \\ \text { ITRI } & \text { - Intalation Toxicology Researeh Institute } \\ \text { SNL } & \text { - Sandia National Laboratories } \\ \text { WIPP } & \text { - Waste Isolation Pilot Plant } \\ \text { LANL } & \text { - Los Alamos National Laboratory } \\ \text { LAAO } & \text { - Los Alamos Area Office } \\ \text { KAO } & \text { - Kinland Area Office }\end{array}$


APPENDIX G 


\section{IMPLEMENTING REGULATIONS REGARDING CULTURAL RESOURCES}

1. Antiquities Act of 1906 (P.L. 59-209);

2. Historic Sites, Buildings, and Antiquities Act of 1935, P.I. 74-292, as amended by P.L. 89-249, P.L. 94-458, and P.I. $96-625$;

3. Archeological Recovery Act of 1960, P.L. 86-523, as amended by P.L. 93-291 (The Archeological and Historic Preservation Act of 1974), P.L. 95-625, P.L. 96-205, and P.I. $96-515$;

4. Executive Order 11593 (1971);

5. President's Memorandum on Environmental Quality and Water Resources Management (.1978); and

6. Archaeological Resources Protection Act of. 1979, P.L. 96095, as amended by P.L. 100-555 and P.L. 100-588;

7. National Historic Preservation Act, P.L. 89-665, as amended by P.L. 91-243, P.L. 93-54, P.L. 94-422, P.L. 94458, P.L. 96-199, P.L. $96-244$, P.I. 96-515, and P.I. 10170

8. 36 CFR 60 - National Register of Historic Places

9. 36 CFR 63 - Determinations of Eligibility for Inclusion in the National Register of Historic Places

10. 36 CFR 65 - National Historic Landmarks Program

11. 36 CFR 78 - Waiver of Federal Agency Responsibilities Under Section 110 of the National Historic Preservation Act

12. 36 CFR 800 - Protection of Historic and Cultural Properties

13. 43 CFR 7 - Protection of Archaeological Resources

\section{Additional Guidance}

1. U.S. Department of Energy Order 1324.7 Departmental History Program

2. U.S. Department of Energy Memorandum - Management of Cultural Resources at Department of Energy Facilities

3. Section 110 Guidelines 